\author{
UNIVERSIDADE DE SÃO PAULO \\ FACULDADE DE CIÊNCIAS FARMACÊUTICAS \\ Programa de Pós-Graduação em Tecnologia Bioquímico Farmacêutica \\ Área de Tecnologia de Alimentos
}

\title{
Desenvolvimento de manjar branco potencialmente probiótico
}

Sabrina Barros de Mattos Corrêa

Dissertação para obtenção grau de

MESTRE

Orientadora:

Profa. Dra. Susana Marta Isay Saad

São Paulo

2006 
Sabrina Barros de Mattos Corrêa

Desenvolvimento de manjar branco potencialmente probiótico

Comissão Julgadora

da

Dissertação para obtenção do grau de Mestre

$\overline{\text { Profa. Dra. Susana Marta Isay Saad }}$ orientador/presidente

$1^{\circ}$. examinador

$2^{\circ}$. examinador

São Paulo, 14 de julho de 2006. 
Para meu pai e meu grande amigo Antonio Celso, pelo carinho, apoio e incentivo. 


\section{AGRADECIMENTOS}

A minha orientadora Profa. Dra. Susana Marta Isay Saad pela paciência, pelos ensinamentos, pela confiança em meu trabalho, pelas realizações obtidas graças a essa parceria e a todos os colegas, que fizeram e fazem parte de seu grupo de pesquisa.

Aos professores, funcionários e colegas do Departamento de Tecnologia Bioquímico- Farmacêutica da Faculdade de Ciências Farmacêuticas da Universidade de São Paulo.

À Profa. Dra. Inar Alves de Castro pela ajuda e pelas valiosas sugestões na condução da análise sensorial e a todos provadores participantes.

Ao Conselho Nacional de Desenvolvimento Científico e Tecnológico (CNPq), à Coordenação de Aperfeiçoamento de Pessoal de Nível Superior (Capes) e à Fundação de Amparo à Pesquisa de São Paulo (FAPESP) pela bolsa e auxílio financeiro concedido.

Às empresas Danisco, Danone, CP-Kelco que colaboraram com parte dos recursos materiais aqui utilizados.

À Profa Dra. Úrsula Maria Lanfer Márques e a técnica Rosa Maria Cerdeira Barros pela fundamental colaboração durante as análises de proteína deste trabalho.

À bibliotecária Leila Aparecida Bonadio pelo auxílio na correção das referências apresentadas neste trabalho.

À Deus, pela força e luz concedida, ajudando-me a realizar este trabalho com grande prazer e a alcançar bons resultados.

A meus amigos e a todos que direta ou indiretamente colaboraram para a realização deste trabalho. 


\section{SUMÁRIO}

1.INTRODUÇÃO

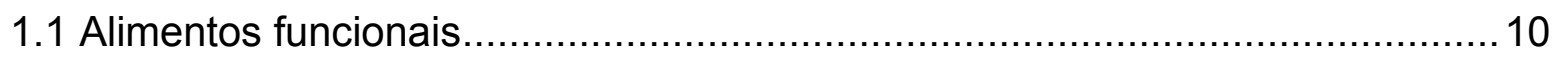

1.2 Probióticos - mecanismos de ação, viabilidade, efeitos benéficos e fatores

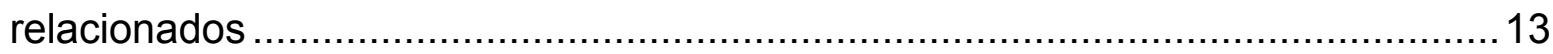

1.3 Prebióticos - definição e efeitos benéficos................................................ 12

1.4 Principais gêneros de bactérias utilizadas como probióticos ..........................18

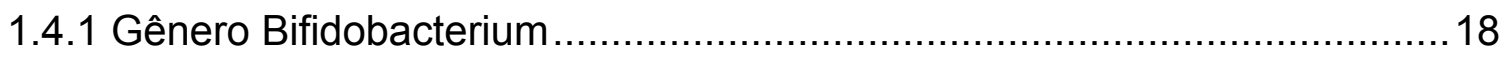

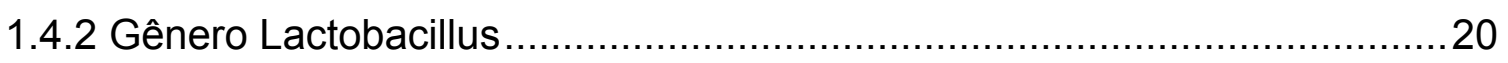

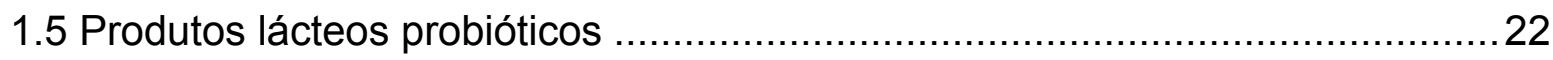

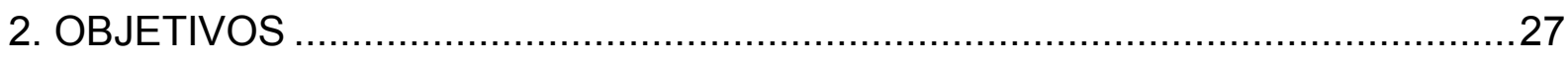

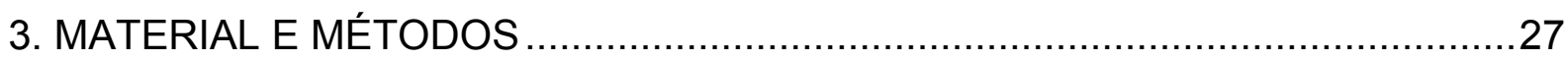

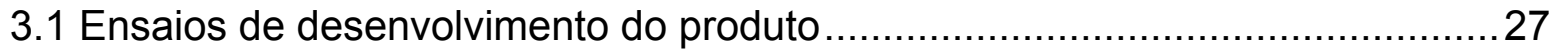

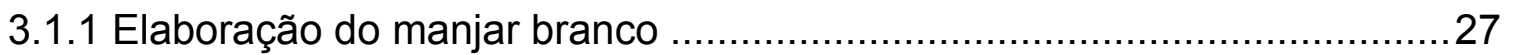

3.1.2 Fabricação de manjar branco de acordo com a proposta inicial - Ensaio 1.29

3.1.3 Fabricação de manjar branco com a adição de goma pectina - Ensaio 2....30

3.1.4 Fabricação de manjar branco com a adição de goma pectina e goma carragena - Ensaio 3

3.1.5 Fabricação de manjar branco com a adição de diferentes hidrocolóides -

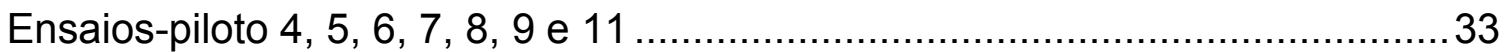

3.1.6 Fabricação de manjar branco com a adição de goma xantana - Ensaio 10.37

3.1.7 Fabricação de manjar branco com a adição de coco ralado - Ensaio 12.38

3.1.8 Fabricação de manjar branco com a adição de goma carragena e coco

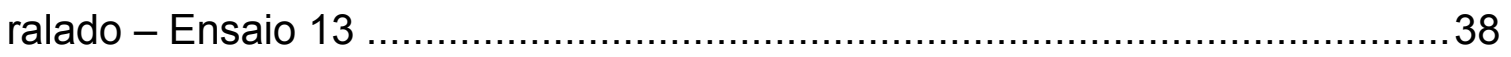

3.1.9 Fabricação de manjar branco com a adição de goma carragena e coco

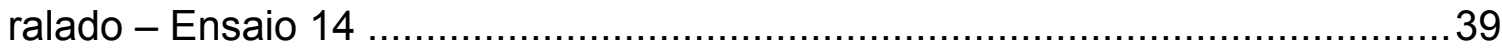

3.1.10 Armazenamento e períodos de amostragem ...................................... 41

3.1.11 Determinação da textura instrumental ................................................... 41

3.1.12 Determinação de parâmetros físico-químicos ………............................4

3.1.13 Determinação dos parâmetros microbiológicos ......................................41

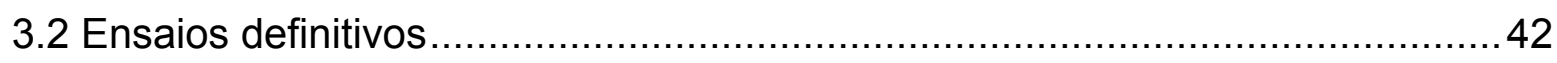

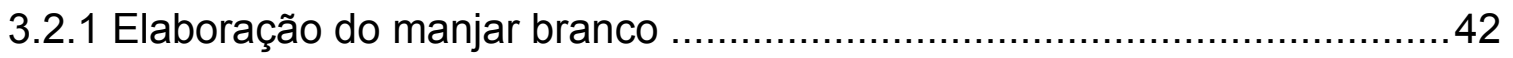




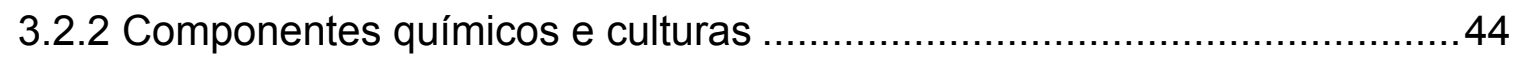

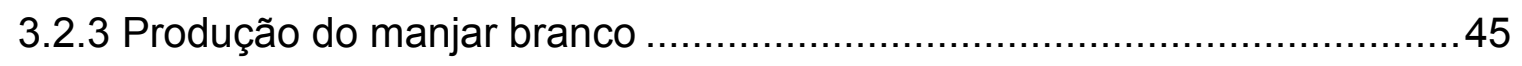

3.2.4 Armazenamento e períodos de amostragem ……….............................46

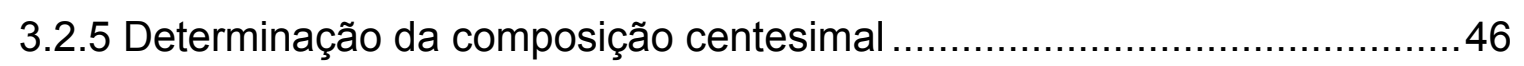

3.2.6 Determinação do perfil de textura instrumental .....................................4

3.2.7 Determinação dos parâmetros físico-químicos .......................................4

3.2.8 Determinação dos parâmetros microbiológicos.......................................48

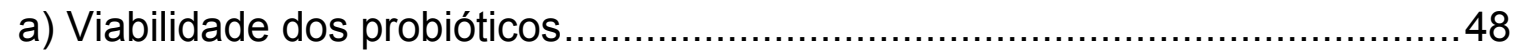

b) Monitoramento de microrganismos contaminantes ......................................49

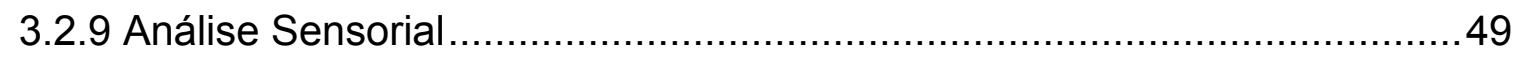

3.2.10 Delineamento experimental e análise estatística ..................................50

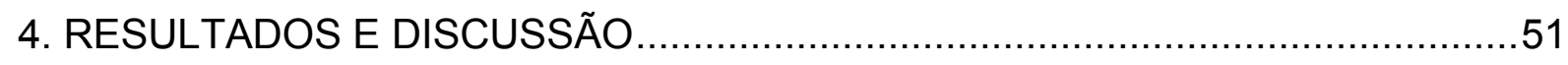

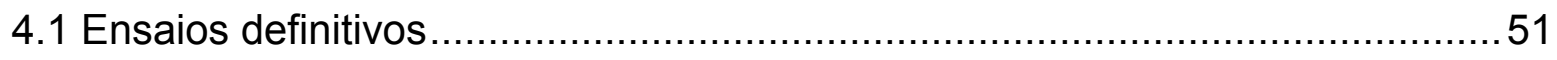

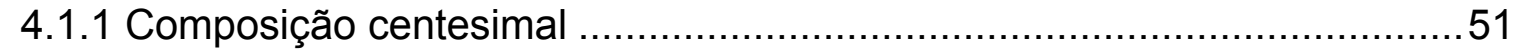

4.1.2 Parâmetros microbiológicos - microrganismos probióticos .......................51

4.1.3 Parâmetros microbiológicos - microrganismos indicadores de

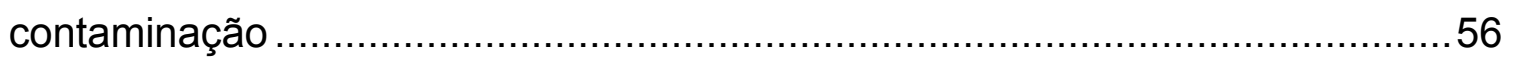

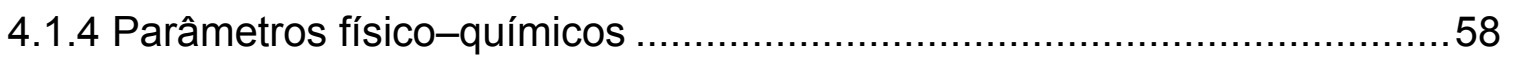

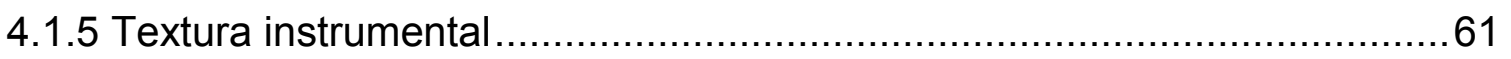

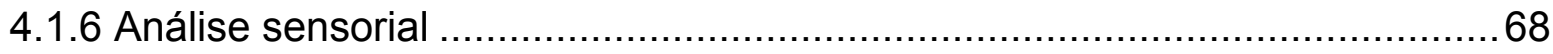

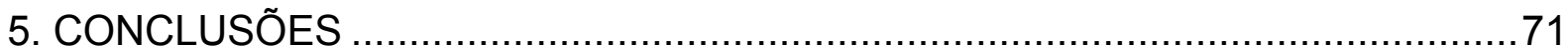

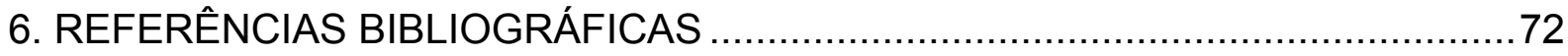




\section{ÍNDICE DE TABELAS}

Tabela 1 - Proporções dos ingredientes adicionados na elaboração do manjar branco do ensaio-piloto 1

Tabela 2 - Populações de L. paracasei (médias) obtidas para o ensaio-1 após 1 e 15 dias de armazenamento sob refrigeração a $4 \pm 1{ }^{\circ} \mathrm{C}$

Tabela 3 - Proporções dos ingredientes adicionados para a elaboração do manjar branco do ensaio-piloto 2

Tabela 4 - Populações de L. paracasei (média) obtidas para o ensaio 2 após 1, 7 e 28 dias de armazenamento a $4 \pm 1{ }^{\circ} \mathrm{C}$

Tabela 5 - Parâmetros de textura obtidos para o manjar branco do ensaio-piloto 2.31 Tabela 6 - Proporções dos ingredientes adicionados para a elaboração do manjar branco do ensaio-piloto 3

Tabela 7 - Parâmetros de textura obtidos para o manjar branco do ensaio-piloto 3.33 Tabela 8 - Populações de L. paracasei (média) obtidas para o ensaio 3 após 1, 7, 14 e 28 dias de armazenamento a $4 \pm 1^{\circ} \mathrm{C}$

Tabela 9 - Proporções dos ingredientes adicionados (não considerando a adição de hidrocolóides), para a elaboração do manjar branco dos ensaios-piloto 4, 5, 6, 7, 8, 9 e 11 .

Tabela 10 - Hidrocolóides ou combinações de hidrocolóides utilizadas para os ensaios-piloto 4, 5, 6, 7, 8, 9 e 11 e suas respectivas proporções

Tabela 11 - Proporções dos ingredientes adicionados para a elaboração do manjar branco do ensaio-piloto 10

Tabela 12 - Proporções dos ingredientes adicionados para a elaboração do manjar branco do ensaio-piloto 12

Tabela 13 - Proporções dos ingredientes adicionados para a elaboração do manjar branco do ensaio-piloto 13

Tabela 14 - Parâmetros de textura obtidos para o manjar branco do ensaio 13 .......39

Tabela 15 - Proporções dos ingredientes adicionados no manjar branco do ensaiopiloto 14

Tabela 16 - Parâmetros de textura obtidos para o manjar branco do ensaio 14

Tabela 17- Variáveis envolvidas na elaboração do manjar branco nos ensaios definitivos 
Tabela 18 - Teor de gordura, proteína, cinzas e carboidratos totais obtidos para os manjares T1, T2, T3 e T4 no produto final - extrato seco (ES) e matéria úmida (MU) - após 1 dia de armazenamento sob refrigeração a $4 \pm 1^{\circ} \mathrm{C}$ (ver tabela 10 para a descrição dos tratamentos T1, T2, T3 e T4).

Tabela 19 - Viabilidade de Bifidobacterium spp.nos tratamentos de manjar branco T2 (em ágar LP-MRS) e T4 (em ágar LP-MRS e em ágar MRS modificado) durante o armazenamento a $4 \pm 1^{\circ} \mathrm{C}$ (veja tabela 10 para descrição dos tratamentos T2 e T4)

Tabela 20 - Viabilidade de Lactobacillus spp. para os tratamentos T3 e T4 durante o armazenamento a $4 \pm 1^{\circ} \mathrm{C}$, e as populações mínimas e máximas obtidas para todas as amostras analisadas (veja tabela 10 para descrição dos tratamentos T3 e T4)...53 Tabela 21 - Populações de coliformes totais (médias de 3 ensaios) obtidas para o manjar branco $\mathrm{T} 1, \mathrm{~T} 2, \mathrm{~T} 3$ e T4 durante o armazenamento a $4 \pm 1^{\circ} \mathrm{C}$ e populações mínimas e máximas obtidas para todas as amostras analisadas (veja tabela 10 para descrição dos tratamentos T3 e T4).

Tabela 22 - Populações de Staphylococcus spp. (médias de 3 ensaios) obtidas para o manjar branco $\mathrm{T} 1, \mathrm{~T} 2, \mathrm{~T} 3$ e T4 durante o armazenamento a $4 \pm 1^{\circ} \mathrm{C}$ e populações mínimas e máximas obtidas para todas as amostras analisadas (veja tabela 10 para descrição dos tratamentos T3 e T4).

Tabela 23 - Populações de bolores e leveduras (médias de 3 ensaios) obtidas para o manjar branco $\mathrm{T} 1, \mathrm{~T} 2, \mathrm{~T} 3$ e T4 durante o armazenamento a $4 \pm 1^{\circ} \mathrm{C}$ e populações mínimas e máximas obtidas para todas as amostras analisadas (veja tabela 10 para descrição dos tratamentos T3 e T4). 58 Tabela 24 - Parâmetros físico-químicos obtidos para os diferentes tratamentos de manjar branco durante o seu armazenamento a $4 \pm 1^{\circ} \mathrm{C}$ (ver tabela 10 para descrição dos tratamentos T1, T2, T3 e T4)

Tabela 25 - Perfil de textura (média \pm desvio-padrão) dos manjares T1, T2, T3 e T4 após $1,7,14,21$ e 28 dias de armazenamento sob refrigeração a $4 \pm 1^{\circ} \mathrm{C}$ (ver tabela 10 para a descrição dos tratamentos T1, T2, T3 e T4) 


\section{ÍNDICE DE FIGURAS}

Figura 1 - Fluxograma contendo as principais etapas de produção do manjar branco dos ensaios pilotos mais relevantes conduzidos neste trabalho 28

Figura 2 - Firmeza obtida para os ensaios-piloto 4, 5, 6, 7, 8, 9 e 11, após 1 dia de armazenamento dos produtos 35

Figura 3 - Adesividade obtida para os ensaios-piloto 4, 5, 6, 7, 8, 9 e 11, após 1 dia de armazenamento dos produtos 35

Figura 4 - Elasticidade obtida para os ensaios-piloto 4, 5, 6, 7, 8, 9 e 11, após 1dia de armazenamento dos produtos. 35

Figura 5 - Coesividade obtida para os ensaios-piloto 4, 5, 6, 7, 8, 9 e 11, após 1 dia de armazenamento dos produtos 36

Figura 6 - Gomosidade obtida para os ensaios-piloto 4, 5, 6, 7, 8, 9 e 11, após 1 dia de armazenamento dos produtos 36

Figura 7 - Mastigabilidade obtida para os ensaios-piloto 4, 5, 6, 7, 8, 9 e 11, após 1 dia de armazenamento dos produtos

Figura 8 - Fluxograma contendo as principais etapas de produção do manjar branco dos ensaios definitivos conduzidos neste trabalho. .43

Figura 9 - Valores médios de $\mathrm{pH}$ para os tratamentos T1, T2, T3 e T4 durante o armazenamento refrigerado do manjar branco a $4 \pm 1^{\circ} \mathrm{C}$ (ver tabela 10 para descrição dos tratamentos T1, T2, T3 e T4) 60 Figura 10 - Valores médios de umidade para os tratamentos T1, T2, T3 e T4 durante o armazenamento refrigerado do manjar branco a $4 \pm 1^{\circ} \mathrm{C}$ (ver tabela 10 para descrição dos tratamentos T1, T2, T3 e T4)...

Figura 11 - Notas de aceitabilidade do manjar branco, medidas através de análises sensoriais durante o período de vida-de-prateleira (7, 14 e 21 dias). Os valores são expressos pela média e barras verticais com intervalos de confiança de 0,95 69 Figura 12 - Interação entre B. longum e $L$. paracasei na aceitabilidade de manjar branco medida pelas análises sensoriais após 21 dias. Os valores são expressos pela média e barras verticais com intervalo de confiança de 0,95 


\section{RESUMO}

A ingestão de alimentos que, além de fornecerem a nutrição, promovem a saúde, como os alimentos funcionais adicionados de probióticos, que auxiliam no equilíbrio da microbiota intestinal, é de vital importância. Em virtude do crescente interesse da indústria e da comunidade científica por novos produtos probióticos, o desenvolvimento de uma sobremesa láctea que permita a adição de probióticos, como o manjar branco, é promissor. O presente trabalho visou desenvolver um manjar branco com a adição dos microrganismos potencialmente probióticos, Lactobacillus paracasei subsp. paracasei e/ou Bifidobacterium longum, adicionados isoladamente e em co-cultura, e avaliar o comportamento dos probióticos e as características do produto ao longo do seu armazenamento refrigerado.

Quatro tratamentos de manjar branco foram produzidos (com 3 repetições cada): T1 (controle - sem a adição de culturas), T2 (com Bifidobacterium longum), T3 (com Lactobacillus paracasei) e T4 (com B. longum + L. paracasei). O produto foi avaliado sensorialmente (após 7,14 e 21 dias de armazenamento a $4 \pm 1^{\circ} \mathrm{C}$, através de escala hedônica estruturada, com 24 provadores não treinados em cada período) e, durante o seu armazenamento por até 28 dias, microbiologicamente quanto à viabilidade dos probióticos e à contagem de contaminantes (coliformes, Escherichia coli, Staphylococcus spp. e bolores e leveduras) e quanto às suas características físico químicas (umidade, $\mathrm{pH}$ ) e de textura instrumental.

Durante o armazenamento dos produtos por 28 dias, as populações médias de $L$. paracasei aumentaram de 6,6 para 8,6 log UFC/g e de 6,4 para 7,3 log UFC/g, para T3 e T4, respectivamente. B. longum revelou populações sempre entre 7,3 e 7,5 log UFC/g e entre 7,1 e 7,5 log UFC/g para T2 e T4, respectivamente. O manjar T3 resultou em uma redução mais acentuada do $\mathrm{pH}(p<0,05)$, mas a umidade não foi significativamente distinta para os diferentes produtos $(p>0,05)$. A firmeza de todos os tratamentos de manjar branco estudados aumentou ao longo do armazenamento e o manjar T2 apresentou menor firmeza a partir de 14 dias de armazenamento. No entanto, essa diferença não foi observada durante a análise sensorial do manjar branco para nenhum dos tratamentos. De fato, a avaliação sensorial não detectou diferenças evidentes da adição de culturas isoladas ou em co-cultura de bifidobacteria e $L$. paracasei nas características sensoriais. Não foi observada nenhuma diferença significativa entre os tratamentos $(p=0,06)$ durante o período de vida-de-prateleira de 21 dias $(p=0,24)$. Entretanto, foi observada uma tendência de melhores notas para os manjares adicionados de microrganismos probióticos, comparados ao manjar branco controle e uma tendência de redução das notas quando ambos os microrganismos foram adicionados. A adição de Lactobacillus paracasei e Bifidobacterium longum ao manjar branco resultou em um produto potencialmente probiótico e com excelentes atributos sensoriais, particularmente quando a adição das culturas foi realizada individualmente. 


\begin{abstract}
The ingestion of foods that promote health in addition to providing basic nutrition, like foods supplemented with probiotics cultures, which may exert a positive effect on the gut indigenous microbiota is becoming increasingly important. The development of a non-fermented dairy dessert which allows the supplementation with probiotics, like coconut flan, appears to be a good option, due to the growing interest that food companies and the scientific community have demonstrated in new probiotic products. The present research aimed to study the viability of Lactobacillus paracasei subsp. paracasei and Bifidobacterium longum, added as single cultures or in coculture, in coconut flan supplemented with these potentially probiotic cultures and to evaluate the behavior of the probiotics and the features of the product during refrigerated storage.

Coconut flans were produced with no addition of cultures (T1 - control), or supplemented with Bifidobacterium longum (T2), Lactobacillus paracasei subsp. paracasei $(\mathrm{T} 3$ ) and $B$. longum $+L$. paracasei (T4). The products were sensory evaluated (after 7,14 and 21 days of storage, at $4 \pm 1^{\circ} \mathrm{C}$, employing a structured hedonic scales, with 24 untrained panelists at each period) and monitored microbiologically for the viability of the probiotics and the counts of contaminants (coliforms, Escherichia coli, Staphylococcus spp., yeasts and moulds), as well as for their instrumental texture profile and their physicochemical features $(\mathrm{pH}$, moisture) through the 28 days of storage at $4 \pm 1^{\circ} \mathrm{C}$.

During storage of the products for 28 days, the mean populations of $L$. paracase $i$ increased from 6.6 to $8.6 \mathrm{log}$ CFU/g and from 6.4 to $7.3 \mathrm{log}$ CFU/g, for T3 and T4, respectively. B. longum presented populations always between 7.3 and $7.5 \mathrm{log}$ CFU/g, and between 7.1 and $7.5 \log \mathrm{CFU} / \mathrm{g}$ for T2 and T4, respectively. Coconut flan T3 underwent higher decreases in $\mathrm{pH}$ values $(\mathrm{P}<0,05)$. On the other hand, moisture showed no significant differences $(P>0,05)$ between trials and during the shelf life period. The firmness of all coconut flans studied increased during storage, and coconut flan T2 presented lower firmness after 14 days of storage. Nevertheless, this difference was not detected during the sensory evaluation of coconut flans. In fact, the sensory analyses did not shown marked differences from the addition of probiotic cultures of bifidobacteria and $L$. paracasei as single cultures or in co-culture, on sensory features. No significant differences between trials $(P=0,06)$ and during the 21 days of shelf life period $(P=0,24)$ were detected. However, a tendency of better scores for the coconut flans supplemented with the probiotic microorganisms, compared with the control product, and a tendency of reduction of scores when both microorganisms were presented in the coconut flan formulation were observed. The supplementation of coconut flans with Lactobacillus paracasei and Bifidobacterium longum resulted in great potential as a functional food, and with high sensory acceptability, particularly when single cultures were employed.
\end{abstract}




\section{Introdução}

\subsection{Alimentos funcionais}

Atualmente, há uma enorme preocupação em se ingerir alimentos saudáveis, que favoreçam o bem-estar físico e auxiliem na redução do risco de doenças (MATTILA-SANDHOLM et al., 2002). A dieta possui um desempenho significativo, contribuindo para a modulação de várias funções do organismo (KORHONEN, 2002). O uso promissor dos alimentos para promover o bem-estar, a saúde e a redução do risco de doenças tornou-se popular entre os consumidores (ROBERFROID, 1999a). Estes, por sua vez, estão cada vez mais conscientes e informados sobre assuntos ligados à alimentação e à saúde e esperam que os alimentos sejam convenientes, acessíveis e apresentem sabor agradável (NINESS, 1999).

Com o crescente aumento da demanda por alimentos "saudáveis", a pesquisa e o desenvolvimento de novas categorias de produtos têm sido estimuladas na indústria de alimentos de todo o mundo. Nos últimos anos, esses alimentos têm despertado o interesse da comunidade científica e das indústrias (SANDERS, 1998; MATTILA-SANDHOLM et al., 2002; HALSTED, 2003).

O cientista russo Elie Metchnikoff, em 1907, foi o primeiro a chamar atenção para importância da microbiota intestinal na saúde humana. Ele sugeriu que o consumo de alimentos como iogurte, kefir, e "sour milk", que contêm bactérias láticas (LAB), estaria associado à boa saúde e à longevidade (SCHIFFRIN \& BLUM, 2001; HELLER et al., 2003).

Atualmente, o conceito que se tem a respeito da microbiota intestinal de seres humanos leva a acreditar que a mesma tem um papel fundamental na saúde, podendo ser controlada através de uma alimentação equilibrada e específica. Ela exerce uma influência considerável sobre uma série de reações bioquímicas do ser humano. Quando em equilíbrio, a microbiota impede que microrganismos potencialmente patogênicos causem doenças. Por outro lado, quando em desequilíbrio, o nível de bactérias benéficas no trato intestinal cai, bactérias potencialmente patogênicas encontram espaço para multiplicar continuamente, podendo causar problemas de saúde (ZIEMER \& GIBSON, 1998). 
O trato gastrintestinal é um complexo ecossistema que associa a microbiota residente e células fenotípicas, alinhadas à parede epitelial. A colonização do trato gastrintestinal se dá logo após o nascimento. Os primeiros microrganismos a colonizarem o intestino do recém nascido são as bactérias aeróbicas e as anaeróbicas, como Escherichia coli, Clostridium spp., Streptococcus spp., Lactobacillus spp., Bacteróides spp. e Bifidobacterium spp. Todos os componentes da microbiota do trato gastrintestinal são necessários para o intestino desenvolver suas funções específicas (SERVIN, 2004; ISOLAURI et al., 2004).

A microbiota saudável é definida como aquela que conserva e promove o bemestar e a ausência de doenças, especialmente do trato gastrintestinal. A correção das propriedades da microbiota autóctone desbalanceada constitui a racionalidade da terapia por probióticos (ISOLAURI et al., 2004). O conhecimento da microbiota intestinal e suas interações levaram ao desenvolvimento de estratégias alimentares, objetivando a manutenção e o estímulo das bactérias normais ali presentes (GIBSON \& FULLER, 2000). A saúde do intestino mostrou-se ser a chave para o setor de alimentos funcionais na Europa (MATTILA-SANDHOLM et al., 2002).

Alimentos que produzem efeitos benéficos sobre a saúde são chamados alimentos funcionais. Estes fornecem a nutrição básica e, por meio de mecanismos não previstos pela nutrição convencional, promovem a saúde. Este efeito restringese à prevenção e não à cura das doenças. O objetivo primário dos alimentos funcionais é melhorar, manter e reforçar a saúde dos consumidores via alimentação (SANDERS, 1998; ROBERFROID, 2000; HALSTED, 2003). Uma definição relativamente recente descreve alimentos funcionais como "alimentos que demonstraram afetar beneficamente uma ou mais funções-alvo no organismo, além de promoverem a nutrição, de modo relevante para um aumento do estado de saúde e bem-estar e/ou redução do risco de doenças" (STANTON et al., 2005).

Sanders (1998) enumerou seis causas para o aumento da procura por alimentos funcionais, a saber: os consumidores optam por prevenir ao invés de curar doenças; há um considerável aumento dos custos médicos; os consumidores estão mais bem informados sobre a relação entre a saúde e a nutrição; a tentativa de se retardar o envelhecimento; a tentativa de se combater os males causados pela poluição, por microrganismos e agentes químicos no ar, na água e nos alimentos, e o aumento das evidências científicas sobre sua eficácia. 
Os alimentos funcionais abrangem um mercado global em crescimento significativo, com um rendimento anual estimado em mais de 50 bilhões de dólares. O maior segmento deste mercado encontra-se na Europa, Japão e Austrália e compreende alimentos contendo probióticos, prebióticos e simbióticos (STANTON et al., 2005). O mercado de iogurtes probióticos está bem estabelecido, mas o setor que mais cresce recentemente é o setor de bebidas probióticas (MATTILASANDHOLM et al., 2002).

Segundo Gardiner et al. (1999), estudos de mercado revelam uma demanda global crescente por alimentos funcionais contendo culturas vivas de microrganismos probióticos. Como conseqüência, o número de produtos alimentícios contendo esses microrganismos "promotores de saúde" encontra-se em expansão. Os produtos fermentados fazem parte da dieta da maioria das pessoas ao redor do mundo. Numerosos artigos científicos foram publicados sobre os benefícios para a saúde associados ao consumo de produtos lácteos fermentados (DAVE et al., 1998; JELEN \& LUTZ, 1998; MINELLI et al., 2004). No mercado europeu, observa-se crescimento no desenvolvimento de produtos lácteos fermentados e funcionais, refletindo grande interesse no estudo de alimentos que demonstrem benefícios para a saúde. Estimase que $13 \%$ do total de iogurtes vendidos na Europa contenham probióticos (DALY et al., 1998). No Japão, pode-se encontrar mais de 53 diferentes tipos de produtos lácteos contendo microrganismos probióticos (SHAH, 2000).

No Brasil, o número de produtos lácteos comercializados vem crescendo, através da criação de novas categorias ou pela reformulação dos produtos que já se encontram no mercado. O volume de venda desses produtos nos últimos anos corresponde a aproximadamente $25 \%$ do total de produtos alimentícios comercializados. O mercado, tendo em vista a maior exigência por parte do consumidor por produtos que satisfaçam do ponto de vista nutricional, de vida-deprateleira, aceitabilidade e preço, mostra-se cada vez mais competitivo (ALEGRO, 2003).

São encontrados no mercado brasileiro alguns tipos de alimentos contendo probióticos, como iogurtes, leite em pó destinado a recém nascidos, sobremesas lácteas fermentadas e leites fermentados aromatizados ou não. Estima-se um consumo de leites fermentados contendo probióticos no Brasil de cerca de 120 mil toneladas por ano (LEITES, 2000). 


\subsection{Probióticos - mecanismos de ação, viabilidade, efeitos benéficos e fatores relacionados}

Os alimentos funcionais de primeira geração eram constituídos pelos componentes com atividade reconhecidamente benéfica à saúde, como, por exemplo, as vitaminas e o cálcio. Nos últimos anos esse conceito voltou-se, principalmente, para aditivos alimentares que podem exercer efeito benéfico sobre a composição da microbiota intestinal. Os aditivos alimentares que compõem esses alimentos funcionais são os prebióticos e os probióticos (ZIEMER \& GIBSON, 1998).

Os efeitos benéficos de alimentos adicionados de microrganismos vivos (probióticos) na saúde humana, em particular de produtos lácteos para crianças e outras populações de alto risco, têm sido cada vez mais promovidos por profissionais da saúde (FAO/WHO, 2001). Os probióticos, por sua vez, eram classicamente definidos como suplementos alimentares à base de microrganismos vivos adicionados aos alimentos, que beneficiavam a saúde dos consumidores através da manutenção ou melhora do balanço da microbiota intestinal (FULLER, 1989), podendo ser culturas puras ou mistas de microrganismos vivos (HAVENAAR et al., 1992).

Atualmente, a definição aceita internacionalmente caracteriza probióticos como "microrganismos vivos não patogênicos que, quando consumidos em quantidades adequadas, conferem benefícios à saúde do hospedeiro" (FAO/WHO, 2001; SCHIFFRIN et al., 2001; SANDERS, 2003); com controvérsias ainda em discussão se as culturas devem estar viáveis para sua eficácia em todos os casos. Embora seja reconhecido que células mortas podem mediar benefícios fisiológicos, um termo diferente deveria ser utilizado para esses agentes (STANTON et al., 2005).

Probióticos estão sendo considerados como ingredientes alimentares importantes no campo da nutrição. Evidências das funções dos probióticos na manutenção da saúde ou prevenção de doenças estão aumentando e têm sido confirmadas, em alguns casos, pela aplicação de tratamentos cegos com placebos (SANDERS, 2003).

Um microrganismo probiótico deve, necessariamente, sobreviver às condições adversas do estômago, ser resistente aos sais biliares e colonizar o intestino, mesmo que temporariamente, por meio da adesão ao epitélio intestinal onde deverão influenciar o metabolismo e o equilíbrio da microbiota intestinal (ZIEMER \& 
GIBSON, 1998; LEE et al., 1999; MINELLI et al., 2004). A capacidade de algumas cepas de probióticos de aderirem às paredes do intestino é considerada importante, embora a não adesão de microrganismos não impeça sua proliferação, mas sim a colonização (ZIEMER \& GIBSON, 1998; LEE et al., 1999).

Existem três possíveis mecanismos de atuação dos probióticos. O primeiro mecanismo é a supressão do número de células viáveis mediante produção de compostos com atividade antimicrobiana, a competição por nutrientes e por sítios de adesão. O segundo é a alteração do metabolismo microbiano pelo aumento ou diminuição da atividade enzimática, e o terceiro mecanismo é o estímulo da imunidade do hospedeiro, por meio do aumento dos níveis de anticorpos e o aumento da atividade dos macrófagos (FULLER, 1989). Segundo Naidu e Clemens (2000), o espectro da atividade dos probióticos pode ser dividido em efeitos nutricionais, fisiológicos e antimicrobianos.

Diversos autores vêm sugerindo possíveis efeitos benéficos de culturas probióticas sobre a saúde do hospedeiro (SANDINE et al., 1972; GILLILAND \& SPEAK, 1977; KIM \& GILLILAND, 1983; FULLER, 1989; GILLILAND, 1988; TEJADA-SYMON et al., 1999; LEE et al., 1999; GOMES \& MALCATA, 1998; SHORTT, 1999; SREEKUMAR \& HOSSONO, 2000; NAIDU \& CLEMENS, 2000; CHARALAMPOPOULOS et al., 2002; MINELLI et al., 2004; SHAH \& LANKAPUTHRA, 1997; CHARTERIS et al., 1998; JELEN \& LUTZ, 1998; KLAENHAMMER, 2001; TUOHY et al., 2003). Entre esses, os que mais se destacam são (SAAD, 2006):

- Modulação da microbiota intestinal e promoção da resistência gastrintestinal à colonização por patógenos: através de mecanismos que incluem a competição por sítios de adesão, a competição por nutrientes e a produção de compostos antimicrobianos, como bacteriocinas, ácidos orgânicos, peróxido de hidrogênio e outros compostos, os probióticos inibem a adesão e a colonização de microrganismos patogênicos e auxiliam a recompor a microbiota intestinal, inclusive após o uso de antibióticos;

- Promoção da digestão da lactose em indivíduos intolerantes a esse açúcar;

- Estimulação do sistema imune: grande parte das evidências in vitro e de modelos animais e humanos sugerem que os probióticos podem estimular tanto a resposta imune não específica quanto específica. Esses efeitos positivos sobre o sistema imunológico ocorrem sem o desencadeamento de uma resposta inflamatória 
prejudicial. Entretanto, nem todas as cepas de bactérias láticas são igualmente efetivas. A resposta imune pode ser aumentada, quando um ou mais probióticos são consumidos concomitantemente e atuam sinergisticamente, como parece ser o caso dos Lactobacillus administrados em conjunto com Bifidobacterium (KOPP. HOOLIHAN, 2001; CALDER, KEW, 2002; VAN DE WATER, 2003).

- Alívio da constipação;

- Aumento da absorção de minerais;

- Produção de vitaminas.

Embora ainda não comprovados, outros efeitos atribuídos a essas culturas são a diminuição do risco de câncer de cólon e de doença cardiovascular. São sugeridos, também, uma diminuição das concentrações plasmáticas de colesterol, efeitos antihipertensivos, redução da atividade ulcerativa de Helicobacter pylori, controle da colite induzida por rotavirus e por Clostridium difficile, prevenção de infecções urogenitais, além de efeitos inibitórios sobre a mutagenicidade (SHAH \& LANKAPUTHRA, 1997; CHARTERIS et al., 1998; JELEN \& LUTZ, 1998; KLAENHAMMER, 2001; KAUR et al., 2002; TUOHY et al., 2003; SAAD, 2006).

A base para seleção de bactérias probióticas leva em conta os seguintes critérios preferenciais: o gênero ao qual pertence à bactéria ser de origem humana, a estabilidade frente ao ácido e à bile, a capacidade de aderir à mucosa intestinal, a capacidade de colonizar ao menos temporariamente o trato gastrintestinal humano, a capacidade de produzir compostos antimicrobianos e ser metabolicamente ativo no nível do intestino. Ainda inclui a segurança para uso humano, ter histórico de não patogenicidade e não estar associada a outras doenças, tais como endocardite, além da ausência de genes determinantes da resistência aos antibióticos (COLLINS et al., 1998; LEE et al., 1999; SAARELA et al., 2000).

Bactérias láticas estão entre os microrganismos probióticos mais importantes, tipicamente associados com o trato gastrintestinal humano. O emprego de bactérias láticas em alimentos é de longa data; grande parte das cepas empregadas são consideradas microrganismos comensais sem potencial patogênico (COLLINS et al., 1998; LEE et al., 1999).

As bactérias láticas podem ser divididas em categorias, em geral, de acordo com os metabólitos produzidos ou com a temperatura ótima de crescimento. Bactérias láticas homofermentativas produzem, como seu principal produto, ácido lático (70$90 \%$ ), enquanto que as heterofermentativas produzem ácido acético, gás carbônico 
e etanol, além do ácido lático, sendo que o ácido lático representa cerca de $50 \%$ do total de metabólitos presentes. Bactérias láticas mesófilas multiplicam-se na faixa de temperatura ótima de $21-30^{\circ} \mathrm{C}$, enquanto as termófilas preferem temperaturas mais elevadas, da ordem de 40 - 45ㄷ (SALMINEN \& VON WRIGHT, 1993).

Tradicionalmente, bactérias láticas têm sido classificadas com base em suas propriedades fenotípicas, em sua morfologia, modo de fermentação de glicose, crescimento a diferentes temperaturas, configuração ácido lática e fermentação de vários carboidratos. Estudos baseados na seqüência de análise comparativa $16 \mathrm{~S}$ RNAr, entretanto, mostraram que algumas classificações geradas com base nas características fenótipicas não correspondem com a relação filogenética sugerida. Algumas espécies não podem ser identificadas por suas características fenotípicas. Isso inclui bactérias dos grupos L. acidophilus, L. casei e algumas cepas de bifidobacterias, que foram introduzidas em alimentos probióticos. Conseqüentemente, técnicas moleculares modernas têm se tornado extremamente importantes para a identificação de espécies ou para a diferenciação de cepas probióticas. Cepas probióticas são selecionadas para aplicação em alimentos com base em suas propriedades funcionais e fisiológicas, algumas das quais podiam ser determinadas in vitro (HOLZAPFEL et al., 2001). Posteriormente, os testes in vitro passaram a ser considerados úteis apenas para estabelecer mecanismos de ação, não podendo ser considerados para prever a funcionalidade no organismo humano. Assim sendo, as cepas só podem ser consideradas probióticas se for demonstrado clinicamente que exercem benefícios fisiológicos (REID et al., 2003).

Segundo o FDA, algumas bactérias são permitidas para o emprego em alimentos e entre elas encontram-se as probióticas. Entre os microrganismos empregados como probióticos destacam-se as bactérias pertencentes aos gêneros Bifidobacterium e Lactobacillus e, em menor escala, as bactérias Enterococcus faecium e Streptococcus thermophilus (COLLINS et al., 1998; LEE et al., 1999; SANDERS \& KLAENHAMMER, 2001).

As bactérias mais amplamente utilizadas pela indústria de alimentos pertencem ao grupo das bactérias láticas, embora algumas bifidobacterias e leveduras também sejam utilizadas (LEE et al., 1999). O íleo terminal e o cólon parecem ser, respectivamente, os locais de preferência para colonização intestinal dos lactobacilos e bifidobacterias (CHARTERIS et al., 1998; BIELECKA et al., 2002). Entretanto, deve ser salientado que o efeito de uma bactéria é específico para cada 
cepa, não podendo ser extrapolado, inclusive para outras cepas da mesma espécie (GUARNER \& MALAGELADA, 2003).

\subsection{Prebióticos - definição e efeitos benéficos}

Os prebióticos são ingredientes não digeríveis incorporados aos alimentos no sentido de selecionar determinadas bactérias da microbiota intestinal, por meio de sua atuação, como um substrato seletivo no cólon (ZIEMER \& GIBSON, 1998; LEE et al., 1999). Eles estimulam seletivamente a proliferação ou atividade de populações de bactérias desejáveis deste local (MATTILA-SANDHOLM et al., 2002). Esses componentes atuam mais freqüentemente no intestino grosso, embora eles possam ter também algum impacto nos microrganismos do intestino delgado (GILLILAND, 2001).

Zubillaga et al. (2001) referem-se a prebióticos como sendo substâncias como lactulose, lactitol, xilitol, inulina e alguns oligossacarídeos não digeríveis que estimulam seletivamente a multiplicação de bifidobacterias no cólon. Estas, por sua vez, são uma das mais eficientes na utilização de carboidratos não digeríveis, fato que resulta em vantagem competitiva na sua multiplicação em relação a outras espécies, justificando assim o consumo de prebióticos. A tolerância das bifidobacterias ao microambiente ácido, formado pela fermentação dos prebióticos e pela produção dos ácidos graxos de cadeia curta, contribui para sua seleção (GRITTENDEN, 1999).

Os ingredientes dos alimentos classificados como prebióticos geralmente exibem as seguintes características: limitada hidrólise e absorção no trato gastrintestinal superior; estimulação seletiva de bactérias benéficas no cólon; potencial para reprimir patógenos e limitar virulência por processos como a imunoestimulação e estímulo da microbiota benéfica que promove a resistência à colonização por patógenos (KLAENHAMMER, 2001). Apesar da existência de evidências preliminares sobre o efeito hipotrigliceridêmico desses ingredientes, o mecanismo de ação dos prebióticos sobre o metabolismo lipídico de humanos ainda não foi elucidado (PEREIRA \& GIBSON, 2002).

Dentre os prebióticos que têm recebido maior atenção, destacam-se a inulina e os oligossacarídeos, especialmente os frutooligossacarídeos como a oligofrutose (FOOKS et al., 1999; GILLILAND, 2001). 


\subsection{Principais gêneros de bactérias utilizadas como probióticos}

\subsubsection{Gênero Bifidobacterium}

O gênero Bifidobacterium se apresenta na forma de bacilos Gram-positivos, anaeróbios restritos, heterofermentativos, produzindo ácido lático e ácido acético como produtos finais do metabolismo de carboidratos. Ele compreende mais ou menos vinte e cinco espécies de bacilos catalase-negativos, imóveis, cujas temperaturas mínimas e máximas de crescimento oscilam entre 25 e $28^{\circ} \mathrm{C}$ e entre 43 e $45^{\circ} \mathrm{C}$, respectivamente. Multiplicam-se melhor em faixas de $\mathrm{pH}$ de 5 a 8 . Sua denominação deve-se ao fato de que essas bactérias se apresentam em forma $Y$ ou $\mathrm{V}$, ou forma bífida. Entretanto, a taxonomia dessas bactérias tem sido alterada desde que foram isoladas pela primeira vez. Bifidobacterias são consideradas probióticas, uma vez que resistem à acidez do estômago e à ação dos sais biliares, sobrevivem ao trânsito intestinal e chegam ao cólon em quantidades significativas. Essas bactérias vivas possuem a capacidade de influenciar a microbiota endógena, resultando em efeitos fisiológicos desejáveis como a alteração de sua atividade enzimática e do trânsito intestinal, uma vez que produzem, além do ácido lático, o ácido acético, que possui características bacteriostáticas, restringindo a multiplicação de bactérias patogênicas e putrefativas (BLANCHETTE et al., 1996; ARUNACHALAM, 1999; DAIGLE et al., 1999).

O gênero Bifidobacterium é considerado como pertencente ao grupo das bactérias láticas, devido a propriedades bioquímicas e fisiológicas e nichos ecológicos (inclusive o trato gastrintestinal) em comum com outros gêneros de bactérias láticas. Esse fato ocorre, apesar dos gêneros mais importantes do grupo das bactérias láticas pertencerem ao filo das bactérias Gram-positivas com baixo (< $50 \%$ ) conteúdo de guanina e citosina, ao contrário do que ocorre com o gênero Bifidobacterium (KLEIN et al., 1998).

Dentre as bactérias pertencentes ao gênero Bifidobacterium, pode-se destacar $B$. bifidum, B. breve, B. infantis, B. lactis, B. longum e B.thermophilum (COLLINS et al., 1998; LEE et al., 1999; SANDERS \& KLAENHAMMER, 2001).

Boylston et al. (2004) relataram que, sob condições típicas de digestão $(\mathrm{pH}$ 1,53,0), B. longum 1971 e B. pseudolongum 20097 são mais tolerantes a condições 
ácidas do que outras 7 cepas de bifidobacterias analisadas. Após um período de $3 \mathrm{~h}$ de incubação, a contagem destas duas cepas ácido-tolerantes decresceu menos que 1 ciclo logarítmico, enquanto a contagem das células viáveis de outras cepas de bifidobacterias analisadas diminuiu até 7 log.

Alguns dos principais substratos para ao multiplicação de bifidobacterias no cólon são os carboidratos da dieta que não são digeridos na parte superior do trato gastrintestinal. Estes carboidratos são assimilados preferencialmente por estas, promovendo sua proliferação no intestino. A capacidade que esses microrganismos têm de metabolizar carboidratos não digeríveis depende de suas atividades glicosídicas (NORIEGA et al., 2004).

Além da glicose, todas as bifidobacterias de origem humana como, por exemplo, B. longum, B. breve e B. infantis, estão aptas a fermentar lactose, galactose e frutose como fontes de carbono. Bifidobacteria fermenta glicose via frutose-6-fosfato e a enzima chave envolvida na fermentação glicolítica, frutose-6-fosfato fosfoquetolase, que pode ser utilizada como um caráter taxonômico na identificação do gênero, porém não diferencia as espécies (GOMES et al., 1999; ARUNACHALAM, 1999).

Cepas do gênero Bifidobacterium vêm sendo empregadas em diversos produtos lácteos, entre eles alguns tipos de queijo. Em estudo com queijo tipo cheddar, utilizando as cepas probióticas Bifidobacterium lactis Bb-12 e Bifidobacterium longum BB536, Mc Brearty et al. (2001) relataram que apenas as cepas de B. lactis $\mathrm{Bb}-12$ mantiveram níveis de células viáveis, de $10^{8} \mathrm{UFC} / \mathrm{g}$, no queijo após seis meses de armazenamento, enquanto $B$. longum BB536 sobreviveu apenas até a concentração de $10^{5} \mathrm{UFC} / \mathrm{g}$. Segundo os autores, a sobrevivência do $B$. lactis Bb-12 no queijo cheddar pode ser devida à natureza da cepa, à baixa sensibilidade ao oxigênio e uma melhor tolerância ao sal. Portanto, a cepa de B. lactis Bb-12 mostrou-se mais conveniente na adição ao queijo cheddar, sobrevivendo à produção do queijo e a seu armazenamento em altas concentrações. Ainda segundo os autores, a presença desse microrganismo no queijo não alterou sua composição e contribuiu para o sabor do cheddar em um estágio inicial, comparado ao queijo controle. Esse estudo demonstrou que o queijo cheddar é um produto alimentício conveniente para a adição de microrganismos probióticos.

Daigle et al. (1999) relataram estudo com queijo fermentado semelhante ao queijo cheddar. Os autores detectaram concentrações acima de $10^{6} \mathrm{UFC/g}$ de 
bifidobacterias durante pelo menos 12 semanas, tempo de armazenamento do queijo. Paralelamente, foi constatado que a cepa de $B$. infantis manteve sua atividade metabólica durante o armazenamento dos queijos, sem nenhum impacto sobre as suas características organolépticas, uma vez que o painel sensorial não pôde detectar diferenças entre os queijos com e sem adição de bifidobacterias. Nenhuma diferença significativa foi observada na contagem de bifidobacterias durante o armazenamento.

A incorporação de bifidobacterias em produtos láticos é dificultada devido à necessidade de um ambiente anaeróbico e valores de $\mathrm{pH}$ próximos a 6,5-7,0 (MEDICl et al., 2004).

\subsubsection{Gênero Lactobacillus}

O gênero Lactobacillus é filogeneticamente diverso. É descrito como um grupo heterogêneo de bastonetes regulares, Gram-positivos e não esporulados. A divisão clássica dos lactobacilos está baseada em suas características fermentativas: (1) obrigatoriamente homofermentativos; (2) facultativamente heterofermentativos; e (3) obrigatoriamente heterofermentativos. Diversos lactobacilos obrigatoriamente homofermentativos e facultativamente heterofermentativos e alguns obrigatoriamente heterofermentativos são utilizados em alimentos fermentados. Porém, esse último grupo é comumente associado à deterioração de alimentos (STILES \& HOLZAPFEL, 1997).

Lactobacillus estão presentes em produtos lácteos como iogurte, cremes acidificados e alimentos fermentados. Esses alimentos não garantem sempre a reposição ideal da microbiota intestinal, principalmente devido ao fato de muitas vezes as bactérias não estarem mais viáveis (REHM et al., 1993).

Dentre as bactérias láticas pertencentes ao gênero Lactobacillus, destacam-se $L$. acidophilus, L. delbrueckii subsp. bulgaricus, L. helveticus, L.casei subsp. paracasei e subsp. tolerans, L. paracasei, L. fermentum, L. reuteri, L. johnsonii, L. plantarum, L. rhamnosus e L. salivarius (COLLINS et al.,1998; LEE et al., 1999; SANDERS \& KLAENHAMMER, 2001).

Lactobacillus casei faz parte das espécies homofermentativas anaeróbias facultativas. São bactérias Gram-positivas, pertencentes ao grupo das bactérias láticas e, assim como outras bactérias láticas, são tolerantes a ácidos e possuem um 
metabolismo estritamente fermentativo, tendo o ácido lático como produto final mais importante (KANDLER \& WEISS, 1986). O grupo L. casei compreende bactérias láticas fenotipicamente e geneticamente heterogêneas, incluindo as espécies Lactobacillus casei, Lactobacillus paracasei, Lactobacillus zeae e Lactobacillus rhamnosus, que são lactobacilos homofermentativos típicos do hospedeiro humano (FELIS et al., 2001; HOLZAPFEL \& SCHILLINGER, 2002). As cepas de Lactobacillus casei subsp. paracasei têm sido freqüentemente empregadas como probióticos isolados ou em culturas mistas nas indústrias de alimentos (STILES \& HOLZAPFEL, 1997; STANTON et al., 1998; FELIS et al., 2001; ITSARANUWAT et al., 2003; MEDICl et al., 2004).

Industrialmente, L. casei tem aplicação como microrganismo probiótico nos alimentos, já que se adaptam facilmente a estes e podem ser isolados de produtos fermentados, produtos vegetais frescos e fermentados e do trato intestinal de humanos e de animais. Lactobacillus casei é considerado muito eficiente, por sobreviver à passagem pelo trato gastrintestinal e colonizar efetivamente o trato digestivo intestinal, balanceando a microbiota intestinal. Esse microrganismo possui a capacidade de colonizar vários ambientes naturais e ambientes criados pelo ser humano, como boca, trato gastrintestinal e vagina humana, laticínios e produtos vegetais, esgoto e alimentos deteriorados. Está especificamente associado à fermentação do pão e algumas fermentações de queijos em salmouras, além de também causar deterioração de queijos pela fermentação de citrato convertido em dióxido de carbono. L. casei resiste a ácidos gástricos e à bile, aderindo à mucosa do intestino humano, colonizando o seu trato gastrintestinal e impedindo a ação de bactérias potencialmente patogênicas, como determinadas cepas de E.coli, Streptococcus, Clostridium e Salmonella (VINDEROLA et al., 2000; GARDINER et al., 1998; STILES \& HOLZAPFEL, 1997; FELIS et al., 2001; HAMMES \& HERTEL, 2002).

Cepas do gênero Lactobacillus vêm sendo empregadas em diversos produtos lácteos, entre eles alguns tipos de queijo. Gardiner et al. (1998) relataram um estudo com queijo tipo cheddar, utilizando a cepa probiótica L. paracasei, no qual foi possível constatar que estas cepas se multiplicaram, resultando em altos números de células viáveis após 8 meses de maturação do queijo, mesmo quando adicionadas em um inóculo relativamente pequeno. 
Menéndez et al. (2000) relataram que o processamento de queijo tipo arzúaulloa, com adição de cepas de Lactobacillus mesófilos homofermentativos contribuiu no aumento da acidificação durante a maturação do queijo, o que conferiu os aromas desejáveis de iogurte e manteiga, através de uma moderada atividade lipolítica das cepas de Lactobacillus.

\subsection{Produtos lácteos probióticos}

Os produtos lácteos fermentados ou não fermentados são os alimentos mais populares utilizados para aplicação de microrganismos probióticos com concentrações apropriadas de células viáveis durante a sua vida-de-prateleira. Dentre esses produtos, destacam-se o leite, iogurte, sorvete e sobremesas, como, por exemplo, sobremesa de soja congelada e musse, sendo um desafio tecnológico para as indústrias de alimentos (LAROIA et al., 1991a; HATTINGH \& VILJOEN, 2001; KRISTO et al., 2003; MEDICI et al., 2004; BOYLSTON et al., 2004; HEENAN et al., 2004; KOURKOUTAS et al., 2005; ARAGON-ALEGRO et al., 2006).

A espécie de bactéria fermentativa presente define as características de textura e aroma do produto final (OLIVEIRA et al., 2002). O metabolismo das bactérias láticas e a interação entre as cepas selecionadas são responsáveis pela produção de ácido lático e de vários outros compostos que determinam as propriedades típicas de cada produto (MATTILLA-SANDHOLM et al., 2002).

Uma seleção adequada de cepas deve ser conduzida para o processamento de produtos lácteos probióticos (VINDEROLA \& REINHEIMER, 2003). Para a utilização de culturas probióticas na tecnologia de fabricação de produtos alimentícios, além da seleção das cepas probióticas para uso humano, as culturas devem ser empregadas com base no desempenho tecnológico para a sua utilização. Desta maneira, essas culturas devem apresentar boa multiplicação, promovendo propriedades sensoriais adequadas ao produto, e apresentar-se estáveis e viáveis durante o seu armazenamento. Desta forma, podem ser manipuladas e incorporadas em produtos alimentícios, sem perder a viabilidade e a funcionalidade, resultando em produtos com textura e aroma adequados (OLIVEIRA et al., 2002). Assim sendo, além de boa viabilidade no intestino, as propriedades tecnológicas são pré-requisitos para a utilização potencial de culturas probióticas (KASK et al., 2003). Para se garantir a qualidade final do produto, é importante controlar variáveis como: $\mathrm{pH}$, presença de 
oxigênio, quantidade e qualidade do inóculo e composição do leite (OLIVEIRA et al., 2002).

Produtos lácteos contendo bactérias probióticas, como bifidobacteria ou lactobacilos, selecionadas devido a suas propriedades promotoras de saúde, vêm sendo produzidos há muitos anos. Estas bactérias devem estar viáveis no momento de seu consumo para exercerem seus benefícios à saúde. Além disso, a sua viabilidade deve ser alta na parte final do trato gastrintestinal. As bactérias probióticas só apresentam efeitos biológicos no ambiente intestinal se atingirem uma concentração mínima. Por essa razão, um produto lácteo deve conter, pelo menos, $10^{6}-10^{7}$ UFC/mL ou $\mathrm{g}$ de bactérias probióticas viáveis no momento da disponibilidade para o consumo do produto, e deve ser consumido regularmente, sendo recomendado um consumo de $100 \mathrm{~g}$ por dia de produto probiótico (RYBKA \& FLEET, 1997; VINDEROLA \& RENHEIMER, 2003; MÉDICl et al., 2004). No Brasil, a Comissão Tecnocientífica de Assessoramento em Alimentos Funcionais e Novos Alimentos, instituída junto à Câmara Técnica de Alimentos (BRASIL, 1999) estabeleceu a quantidade mínima diária de microrganismos viáveis que devem ser ingeridos para efeitos terapêuticos é de $10^{8}$ a $10^{9}$ UFC por g ou por $\mathrm{mL}$ (AGÊNCIA NACIONAL DE VIGILÂNCIA SANITÁRIA, 2006), informação esta que ainda não está acessível ao público.

A prática para a fabricação de leites fermentados contendo probióticos é de adicionar bactérias convencionais do iogurte, como L. bulgaricus e $S$. thermophilus, para facilitar o processo de fermentação (SAMONA \& ROBINSON, 1994; SHAH \& LANKAPUTHRA, 1997; DAVE et al, 1998; SHIHATA et al., 2000). L. bulgaricus sintetiza aminoácidos essenciais devido a sua natureza proteolítica, e a sua relação simbiótica com S. thermophilus mostra-se bem estabelecida. Entretanto, $L$. bulgaricus também produz ácido lático durante o armazenamento, por meio de mecanismo denominado pós-acidificação, que é reconhecido por afetar negativamente a viabilidade das bactérias probióticas (DAVE \& SHAH, 1997b; SHIHATA et al., 2000).

Em função da perda de viabilidade, é aconselhável o emprego de probióticos associados a culturas de suporte compostas, de preferência, de S.thermophilus ou de outra cultura, de iogurte ou mesofílicas, com diferentes combinações de cepas de Lactococcus. A seleção de uma cultura de suporte apropriada para cada cultura probiótica é fundamental para a obtenção de produtos frescos fermentados com boa 
sobrevivência de probióticos durante sua vida-de-prateleira (SAXELIN et al., 1999; SAARELA et al., 2000).

Shihata et al. (2000), em estudo sobre o perfil proteolítico de iogurte e culturas probióticas, relataram que bactérias de iogurte são aparentemente mais proteolíticas se comparadas a probióticas. As bactérias do iogurte liberam altas quantidades de aminoácidos livres e demonstraram maior atividade de aminopeptidase e de dipeptil quando comparadas a probióticas. Como resultado, as bactérias de iogurte multiplicam-se mais rapidamente no leite, enquanto as probióticas multiplicam-se mais lentamente, devido à falta de atividade proteolítica e à necessidade de um suprimento de peptídeos e aminoácidos para uma multiplicação ótima.

O extrato hidrossolúvel de soja ("leite" de soja), assim como o leite bovino, é apropriado para a multiplicação de bactérias láticas, especialmente bifidobacteria. Os fatores que estimulam a multiplicação desses microrganismos são os oligossacarídeos, aminoácidos e peptídeos. Produtos de soja são importantes, por terem uma função potencial na prevenção de doenças crônicas, como câncer, osteoporose, arteriosclerose e distúrbios decorrentes da menopausa. Para exercer efeitos probióticos benéficos, as quantidades de bactérias no alimento probiótico e nas fezes após seu consumo são fatores essenciais. A cepa de B. breve, quando adicionada ao extrato de soja fermentado, manteve-se com ótima viabilidade, mesmo após o extrato de soja fermentado ter sido refrigerado por um longo período de tempo. O extrato de soja fermentado adicionado dessa cepa apresentou efeitos benéficos para a saúde humana, mostrando altas populações nas fezes e proliferação total de bifidobacterias (SHIMAKAWA et al., 2002).

Garro et al. (2004) relataram que cepas de B. longum CRL 849 e Lactobacillus fermentum CRL 251 foram usadas como culturas puras e mistas em extrato de soja, com objetivo de se avaliar o efeito da temperatura sobre essas cepas. Os autores observaram que ambas as cepas, quando usadas como culturas puras starter a $37^{\circ} \mathrm{C}$, revelaram grande capacidade de multiplicação em até 8 horas, produzindo uma quantidade substancial de ácido, quando em condições controladas de fermentação, decrescendo posteriormente, quando foi possível verificar uma perda de viabilidade. A cultura pura de B. longum CRL 849 começou a multiplicar-se imediatamente, mas apenas durante 8 horas; a sua máxima contagem após 8 horas foi de $1,52 \times 10^{9} \mathrm{UFC} / \mathrm{mL}$, perdendo sua viabilidade em seguida $\left(2,8 \times 10^{7} \mathrm{UFC} / \mathrm{mL}\right.$ após 24 horas). Já quando $B$. longum CRL 849 foi usado como cultura mista, sua 
viabilidade manteve-se estável durante toda a fase de estacionária de crescimento. Embora a produção de ácidos orgânicos tenha diferido, o pH final obtido foi similar a quando $B$. longum foi usado como cultura pura, mantendo sua viabilidade até o final da fermentação. Os autores concluíram que B. longum CRL 849 pode ser usado como cultura mista starter, sem encontrar dificuldades quanto à viabilidade. A temperatura de $37^{\circ} \mathrm{C}$ mostrou-se ideal para aumentar o desempenho, de B. longum CRL 849, tanto como cultura pura como mista.

Similarmente ao estudo anterior, em estudo com sorvete de iogurte fermentado, com adição de culturas probióticas de Bifidobacterium longum e Lactobacillus acidophilus, o armazenamento refrigerado exerceu pequeno ou nenhum efeito na sobrevivência da cultura probiótica, cujos níveis mantiveram-se suficientes para oferecer efeitos terapêuticos. As características organolépticas e a composição centesimal do sorvete de iogurte mostraram-se ligeiramente influenciadas pelos microrganismos probióticos. Porém, a fermentação sob baixo pH $(5,6)$ aumentou significativamente o sabor ácido do produto. Os autores concluíram que o sorvete de iogurte é um excelente veículo para a incorporação de microrganismos probióticos (DAVIDSON et al., 2000).

Diversos tipos de queijo foram testados como veículos para cepas probióticas de Lactobacillus e de Bifidobacterium, revelando-se apropriados, entre eles: cheddar (DINAKAR \& MISTRY, 1994; GARDINER et al., 1998; MC BREARTY et al., 2001), gouda (GOMES et al., 1998), cottage (BLANCHETTE et al., 1996), crescenza (GOBBETTI et al., 1997), arzúa-ulloa (MENENDEZ et al., 2000), queijo fresco cremoso (ROY et al., 1997), queijo fresco cremoso argentino (VINDEROLA et al., 2000) e queijo minas frescal (BURITI et al., 2005a,b).

Em alguns trabalhos, o queijo minas frescal mostrou-se um veículo apropriado para o emprego de Lactobacillus acidophilus (OKAZAKI et al., 2001; BURITI et al., 2005b) e Lactobacillus paracasei (BURITI et al., 2005a). Os referidos microrganismos probióticos revelaram populações superiores ao mínimo requerido para efeito probiótico $\left(10^{6} \mathrm{UFC} / \mathrm{g}\right)$, ao longo de todo o período de armazenamento dos queijos em refrigeração de 21 dias. Resultados particularmente promissores foram obtidos para Lactobacillus paracasei subsp. paracasei LBC 82 (Danisco), que revelou populações médias, respectivamente, após 1, 7, 14 e 21 dias de armazenamento dos queijos a $5^{\circ} \mathrm{C}$, de 6,61, de 6,88, de 7,69 e de 8,22 log UFC/g, nos queijos acidificados com ácido lático, e de 6,79, de 7,50, de 8,15 e de 8,44 log 
UFC/g, nos queijos acidificados com cultura lática mesofílica do tipo O (BURITI et al., 2005a).

Vinderola et al. (2000) relataram que o processamento de queijo fresco argentino com adição das culturas probióticas B. bifidum, B.longum, Bifidobacterium sp., Lactobacillus acidophilus e Lactobacillus casei, em diferentes combinações pode ser empregado para a obtenção de um produto com boas características de sabor e de textura. As culturas de bifidobacteria, L. acidophilus e L. casei, usadas em diferentes combinações, demonstraram sobrevivência satisfatória durante 60 dias. Em todos os experimentos, o número final de células viáveis manteve-se acima do nível sugerido para efeito probiótico.

Aragon-Alegro et al. (no prelo), por outro lado, estudaram um produto não fermentado adicionado de probiótico - uma musse de chocolate, adicionada de $L$. paracasei subsp. paracasei. O referido produto mostrou ser um excelente veículo para adição do probiótico, não interferindo em suas características sensoriais. $L$. paracasei manteve populações constantes, sempre acima de 7 log UFC/g, durante todo o período de armazenamento da musse.

O mercado de alimentos funcionais alcançou um nível significativo e espera-se que cresça em diversos países. Entretanto, é importante apontar que a máxima expressão das propriedades funcionais reais desses alimentos deve ser conciliada com a aceitação sensorial do produto que estiver sendo desenvolvido (CASTRO et al., 2004). Se o produto não possui ou mantém qualidades organolépticas aceitáveis durante sua vida-de-prateleira, ele não será tolerado pelo consumidor durante repetidas compras. O sucesso comercial de produtos probióticos, ultimamente, depende do sabor e do apelo ao consumidor (HEENAN et al., 2004).

Devido ao crescente interesse da indústria e da comunidade científica por novos produtos probióticos, o presente estudo buscou desenvolver uma sobremesa láctea que permitisse a adição de microrganismos probióticos. O manjar branco ou manjar de coco é uma das mais tradicionais sobremesas do nordeste do Brasil. Ele foi introduzido no Brasil pelos africanos durante o período da escravidão, tendo sido originalmente utilizado por africanos em rituais religiosos. Atualmente, o consumo da sobremesa é bastante difundido no país, uma vez que, além de apresentar um sabor bastante apreciado, é de fácil preparo (COOK BRASIL, 2003). Como se trata de um alimento com características propícias ao desenvolvimento de microrganismos probióticos e, tendo em vista a popularidade da sobremesa, os efeitos benéficos dos 
probióticos e o crescente interesse da indústria no desenvolvimento de produtos probióticos, o manjar branco apresenta boas perspectivas como alimento funcional probiótico.

\section{OBJETIVOS}

Este trabalho teve como objetivos:

a) Desenvolver um manjar branco com a adição dos microrganismos potencialmente probióticos, Lactobacillus paracasei subsp. paracasei e/ou Bifidobacterium longum, adicionados isoladamente e em co-cultura;

b) Acompanhar a viabilidade dos microrganismos probióticos ao longo do armazenamento dos produtos a $4 \pm 1^{\circ} \mathrm{C}$, por até 28 dias;

c) Acompanhar a textura instrumental e as características físico-químicas e microbiológicas dos produtos durante o seu armazenamento a $4 \pm 1^{\circ} \mathrm{C}$, por até 28 dias.

d) Comparar os produtos obtidos através da adição das culturas individuais e associadas e avaliar as possíveis alterações de suas características organolépticas, ao longo do armazenamento a $4 \pm 1^{\circ} \mathrm{C}$, através de análise sensorial.

\section{MATERIAL E MÉTODOS}

\subsection{Ensaios de desenvolvimento do produto}

\subsubsection{Elaboração do manjar branco}

A Figura 1 ilustra, resumidamente, as principais etapas de fabricação dos ensaios pilotos mais relevantes realizados neste trabalho, no sentido de se obter a formulação definitiva do produto estudado. Os ensaios foram realizados em escala laboratorial. 


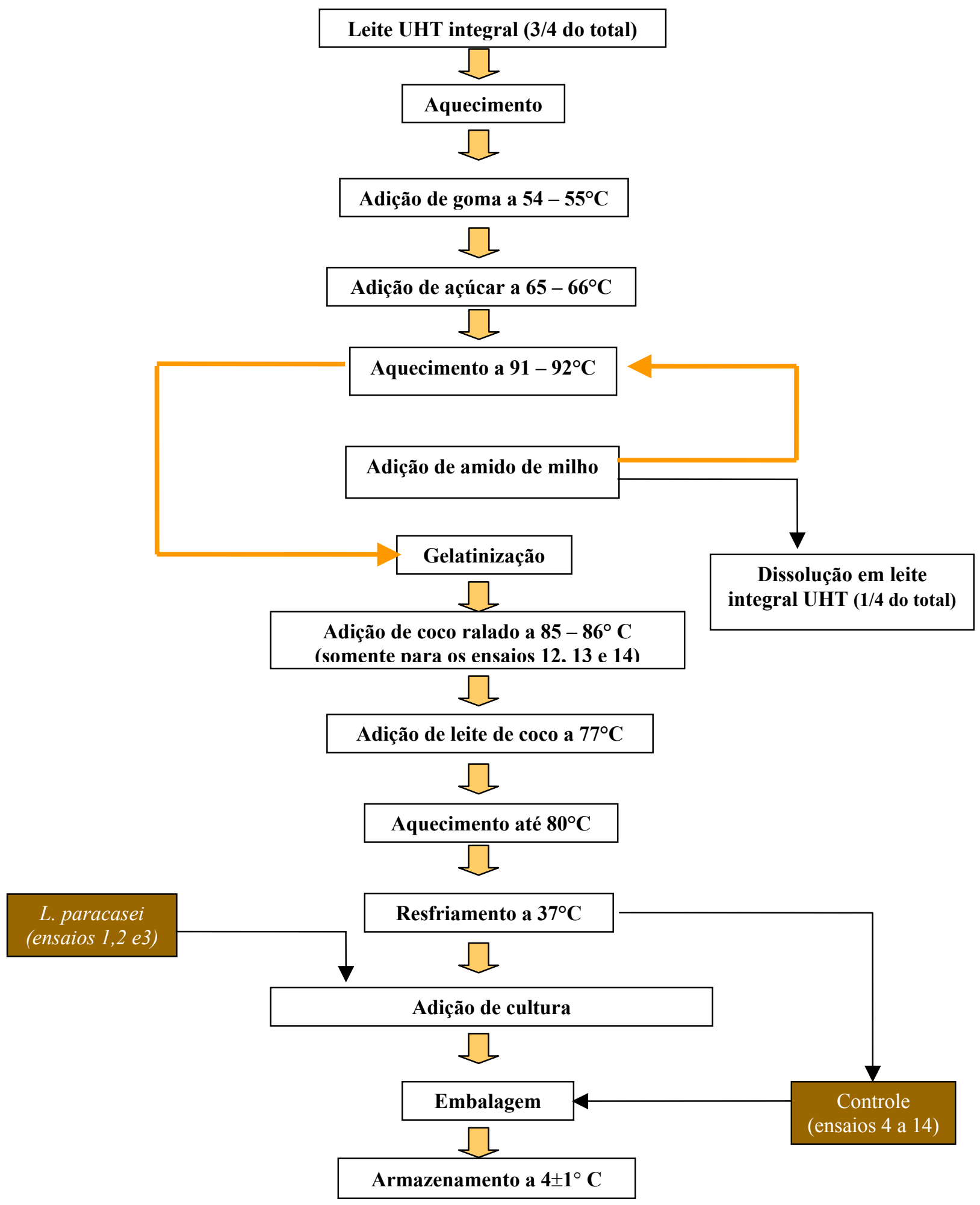

Figura 1 - Fluxograma contendo as principais etapas de elaboração do manjar branco dos ensaios pilotos mais relevantes conduzidos neste trabalho 
3.1.2 Elaboração de manjar branco de acordo com a proposta inicial - Ensaio 1

O ensaio 1 foi realizado para confirmação das proporções de ingredientes utilizados para produção de manjar branco. Foram preparadas 10 amostras com 40 g cada. A tecnologia empregada na elaboração do manjar branco envolveu as etapas apresentadas na Figura 1. As proporções dos ingredientes utilizados na fabricação do manjar são apresentadas na Tabela 1.

Tabela 1 - Proporções dos ingredientes adicionados na elaboração do manjar branco do ensaio-piloto 1

\begin{tabular}{cc}
\hline Ingredientes & \multicolumn{1}{c}{$\%$} \\
\hline leite & 73,77 \\
leite de coco & 16,39 \\
amido de milho & 4,10 \\
açúcar & 5,74 \\
\hline
\end{tabular}

A temperatura do manjar branco, após o seu preparo, era de $80^{\circ} \mathrm{C}$. Após o resfriamento do manjar até uma temperatura de $36-37^{\circ} \mathrm{C}$, adicionou-se a cultura de Lactobacillus paracasei subsp. paracasei (LBC 82, Danisco, Dangé, France), previamente homogeneizada em $40 \mathrm{~mL}$ de leite e incubada a $37^{\circ} \mathrm{C}$ por 1 hora, na proporção de $0,01 \mathrm{~g} / \mathrm{kg}$. A cultura foi fornecida pelo fabricante na forma liofilizada e armazenada congelada. O manjar branco foi, então, embalado em potes plásticos de polipropileno - PP, contendo $40 \mathrm{~g}$ de manjar cada, ocupando um volume médio de $5,0 \mathrm{~cm}^{3}$ em cada pote, que foram selados com tampa metálica e armazenados sob refrigeração a $4 \pm 1^{\circ} \mathrm{C}$.

O teor de umidade, o $\mathrm{pH}$ e a viabilidade de Lactobacillus paracasei foram determinados no dia seguinte à produção. Para este ensaio, o pH e o teor de umidade foram determinados apenas para verificação das características físico químicas do produto, sendo calculados posteriormente para todos os ensaios definitivos. $\mathrm{O} \mathrm{pH}$ encontrado foi de 6,83 e a umidade foi de $74,5 \%$.

A Tabela 2 mostra as populações médias de Lactobacillus paracasei subsp. paracasei obtidas para o ensaio 1.

Devido ao fato deste ensaio ter alcançado níveis muito próximos ao mínimo exigido para as bactérias probióticas apresentarem efeitos benéficos, a 
concentração de microrganismo probiótico inoculada foi aumentada no ensaio seguinte. Neste primeiro ensaio, foi observada uma grande dessora do produto final durante o seu armazenamento refrigerado.

Tabela 2 - Populações de L. paracasei (médias) obtidas para o ensaio-1 após 1 e 15 dias de armazenamento sob refrigeração a $4 \pm 1^{\circ} \mathrm{C}$

\begin{tabular}{cc}
\hline Armazenamento (dias) & População de L. paracasei (log UFC/g) \\
\hline 1 & 6,20 \\
15 & 6,57 \\
\hline
\end{tabular}

Diante deste fato, foram realizados diversos ensaios, modificando-se o processo de elaboração do manjar, através da adição de diversos tipos de hidrocolóides, isolados e em conjunto, e a concentração dos ingredientes adicionados, a fim de se obter um produto com textura, sabor e aroma característicos.

\subsubsection{Elaboração de manjar branco com a adição de goma pectina - Ensaio 2}

Neste ensaio foi testada a goma pectina, mantendo-se a concentração dos outros ingredientes. Foram preparadas 10 amostras com $40 \mathrm{~g}$ cada. A tecnologia empregada na elaboração do manjar branco envolveu as etapas apresentadas na Figura 1. As proporções dos ingredientes utilizados na fabricação do manjar encontram-se na Tabela 3.

Tabela 3 - Proporções dos ingredientes adicionados para a elaboração do manjar branco do ensaio-piloto 2

\begin{tabular}{cr}
\hline Ingredientes & \multicolumn{1}{c}{$\%$} \\
\hline leite & 73,40 \\
leite de coco & 16,31 \\
amido de milho & 4,08 \\
açúcar & 5,71 \\
goma pectina & 0,50 \\
\hline
\end{tabular}

A temperatura do manjar branco, após seu preparo, era de $80^{\circ} \mathrm{C}$. Após o resfriamento do manjar até uma temperatura de $36-37^{\circ} \mathrm{C}$, adicionou-se a cultura probiótica de Lactobacillus paracasei (LBC 82, Danisco) previamente 
homogeneizada em $40 \mathrm{~mL}$ de leite, e incubada a $37^{\circ} \mathrm{C}$, por 1 hora, na proporção de $0,02 \mathrm{~g} / \mathrm{kg}$. O manjar branco foi, então, embalado em potes plásticos de polipropileno - PP, contendo $40 \mathrm{~g}$ de manjar cada, ocupando um volume médio de $5,0 \mathrm{~cm}^{3} \mathrm{em}$ cada pote, que foram selados com tampa metálica e armazenados sob refrigeração a $4 \pm 1^{\circ} \mathrm{C}$.

A viabilidade de Lactobacillus paracasei foi avaliada no dia seguinte à produção.

Foi realizada análise do perfil instrumental de textura, conforme descrito no item 3.1.11.

O produto obtido para o ensaio 2 apresentou, igualmente ao ensaio 1, uma grande dessora. Porém sua textura apresentou-se visivelmente mais firme do que o ensaio 1. Assim o ensaio 2 foi considerado mais adequado do que o ensaio 1.

A Tabela 4 mostra os valores obtidos para as populações de $L$. paracasei obtidas durante o armazenamento do manjar branco para o ensaio 2.

Tabela 4 - População de L. paracasei (média) obtidas para o ensaio 2 após 1, 7 e 28 dias de armazenamento a $4 \pm 1^{\circ} \mathrm{C}$

\begin{tabular}{cc}
\hline Armazenamento (dias) & População de L. paracasei (log UFC/g) \\
\hline 1 & 6,83 \\
7 & 8,43 \\
28 & 8,81 \\
\hline
\end{tabular}

A Tabela 5 mostra os parâmetros de textura encontrados para o ensaio 2 .

Tabela 5 - Parâmetros de textura obtidos para o manjar branco do ensaio-piloto 2

\begin{tabular}{|c|c|c|c|c|c|c|}
\hline Teste & Firmeza & Adesividade & Elasticidade & Coesividade & Gomosidade & Mastigabilidade \\
\hline unidade & g.F & g.s $\mathrm{s}^{-1}$ & & & $\mathrm{~g}$ & $\mathrm{~g}$ \\
\hline 1 & 72,54 & $-122,92$ & 0,52 & 0,72 & 52,33 & 27,23 \\
\hline 2 & 116,3 & $-148,88$ & 0,86 & 0,50 & 58,48 & 50,18 \\
\hline 3 & 115,01 & $-154,94$ & 0,84 & 0,48 & 54,89 & 46,01 \\
\hline Média & 101,29 & $-142,25$ & 0,74 & 0,57 & 55,23 & 41,14 \\
\hline Desvio-padrão & 20,33 & 13,89 & 0,16 & 0,11 & 2,53 & 9,98 \\
\hline
\end{tabular}

Foi realizado um novo ensaio, com o objetivo de aumentar a concentração dos microrganismos probióticos, aumentando-se o tempo de permanência destes no 
leite, possibilitando uma maior multiplicação, antes de adicioná-los ao manjar branco.

3.1.4 Elaboração de manjar branco com a adição de goma pectina e goma carragena - Ensaio 3

Esse ensaio visou testar a combinação da goma pectina e da goma carragena na textura do manjar, mantendo-se a concentração dos demais ingredientes. Foram preparadas 10 amostras com $40 \mathrm{~g}$ cada. A tecnologia empregada na elaboração do manjar branco envolveu as etapas apresentadas na Figura 1. As proporções dos ingredientes utilizados na fabricação do manjar são apresentadas na Tabela 6.

A temperatura do manjar branco, após seu preparo, era de $80^{\circ} \mathrm{C}$. Após o resfriamento do manjar até uma temperatura de $36-37^{\circ} \mathrm{C}$, adicionou-se à cultura de Lactobacillus paracasei subsp. paracasei (LBC 82, Danisco), previamente homogeneizada em $40 \mathrm{~mL}$ de leite e incubada a $37^{\circ} \mathrm{C}$, por 2 horas, na proporção de $0,02 \mathrm{~g} / \mathrm{kg}$. O manjar branco foi, então, embalado em potes plásticos de polipropileno - PP, contendo $40 \mathrm{~g}$ de manjar cada, ocupando um volume médio de $5,0 \mathrm{~cm}^{3} \mathrm{em}$ cada pote, que foram selados com tampa metálica e armazenados sob refrigeração a $4 \pm 1^{\circ} \mathrm{C}$.

Tabela 6 - Proporções dos ingredientes adicionados para a elaboração do manjar branco do ensaio-piloto 3

\begin{tabular}{cr}
\hline Ingredientes & \multicolumn{1}{c}{$\%$} \\
\hline leite & 73,40 \\
leite de coco & 16,31 \\
amido de milho & 4,08 \\
açúcar & 5,71 \\
goma pectina & 0,25 \\
goma carragena & 0,25 \\
\hline
\end{tabular}

A viabilidade de Lactobacillus paracasei foi avaliada no dia seguinte à produção. Foi realizada análise do perfil instrumental de textura, conforme descrito no item 3.1.11.

O produto obtido no ensaio 3 apresentou, visivelmente, uma grande dessora. A textura do manjar apresentou-se extremamente aerada e o sabor doce foi 
prejudicado. A Tabela 7 apresenta os valores de textura encontrados para o ensaio 3. O manjar branco produzido neste ensaio não apresentou as características desejadas. Foram realizados diversos ensaios, modificando-se o processo de elaboração do manjar, através da adição de diversos tipos de hidrocolóides, isolados e em conjunto, e através da mudança da concentração dos ingredientes adicionados com a finalidade de se obter um produto com sabor, aroma e textura característicos. A Tabela 8 apresenta os valores obtidos para as populações de L. paracasei durante o armazenamento do manjar branco para o ensaio 3.

A população de $L$. paracasei no ensaio 3 apresentou-se superior aos valores mínimos de 6 - 7 log UFC/g (Tabela 8), correspondente à ingestão diária de 8 a 9 log UFC contidas em uma porção de $100 \mathrm{~g}$ de alimento lácteo capaz de exercer atividade promotora da saúde como probiótico, conforme citado por LEE \& SALMINEN (1995) e HOIER et al. (1999).

Tabela 7 - Parâmetros de textura obtidos para o manjar branco do ensaio-piloto 3

\begin{tabular}{|c|c|c|c|c|c|c|}
\hline Teste & Firmeza & Adesividade & Elasticidade & Coesividade & Gomosidade & Mastigabilidade \\
\hline unidade & g.F & g.s $\mathrm{s}^{-1}$ & & & $g$ & g \\
\hline 1 & 141,04 & $-93,61$ & 0,71 & 0,46 & 65,41 & 46,46 \\
\hline 2 & 138,88 & $-170,12$ & 0,84 & 0,49 & 68,91 & 57,61 \\
\hline 3 & 144,32 & $-125,26$ & 0,79 & 0,46 & 66,40 & 52,65 \\
\hline Média & 141,41 & $-129,66$ & 0,78 & 0,47 & 66,91 & 52,24 \\
\hline Desvio-padrão & 2,23 & 31,39 & 0,05 & 0,02 & 1,47 & 4,56 \\
\hline
\end{tabular}

Tabela 8 - Populações de L. paracasei (média) obtidas para o ensaio 3 após 1, 7, 14 e 28 dias de armazenamento a $4 \pm 1^{\circ} \mathrm{C}$

\begin{tabular}{cc}
\hline Armazenamento (dias) & População de L. paracasei (log UFC/g) \\
\hline 1 & 6,63 \\
7 & 6,65 \\
14 & 7,57 \\
28 & 8,15 \\
\hline
\end{tabular}

3.1.5 Elaboração de manjar branco com a adição de diferentes hidrocolóides Ensaios-piloto 4, 5, 6, 7, 8, 9 e 11 
Nestes ensaios foram testados diversos tipos de hidrocolóides com o objetivo de se obter um manjar com textura, sabor e aroma característicos, mantendo-se a concentração dos outros ingredientes. L. paracasei não foi adicionado nestes ensaios piloto uma vez que a concentração adequada para sua adição foi definida através do ensaio 3.

Foram preparadas 10 amostras com $40 \mathrm{~g}$ cada para cada ensaio. A tecnologia empregada na elaboração do manjar branco envolveu as etapas apresentadas na Figura 1.

As proporções dos ingredientes utilizados na fabricação do manjar são apresentadas na Tabela 9, com a descrição dos hidrocolóides ou combinações de hidrocolóides utilizados em cada ensaio apresentada na Tabela 10.

Foi realizada análise do perfil instrumental de textura, conforme descrito no item 3.1.11.

Tabela 9 - Proporções dos ingredientes adicionados (não considerando a adição de hidrocolóides), para a elaboração do manjar branco dos ensaios-piloto 4, 5, 6, 7, 8, 9 e 11

\begin{tabular}{cc}
\hline Ingredientes & \% \\
\hline leite & 73,77 \\
leite de coco & 16,39 \\
amido de milho & 4,10 \\
açúcar & 5,74 \\
\hline
\end{tabular}

Tabela 10 - Hidrocolóides ou combinações de hidrocolóides utilizadas para os ensaios-piloto 4, 5, 6, 7, 8, 9 e 11 e suas respectivas proporções

\begin{tabular}{ccccc}
\hline \multicolumn{2}{c}{ Ensaio } & Goma carragena & Goma guar & Gelatina \\
\hline Ensaio & 4 & $0,50 \%$ & & \\
Ensaio & 5 & & $0,50 \%$ & \\
Ensaio 6 & & $0,25 \%$ & $0,50 \%$ \\
Ensaio 7 & $0,25 \%$ & & \\
Ensaio 8 & $0,15 \%$ & & \\
Ensaio 9 & & $0,50 \%$ & $0,25 \%$ \\
Ensaio 11 & $0,40 \%$ & & \\
\hline
\end{tabular}


Os parâmetros avaliados encontrados para os respectivos ensaios apresentamse nas Figuras 2 a 7. A adesividade é um parâmetro cujos dados obtidos são negativos.

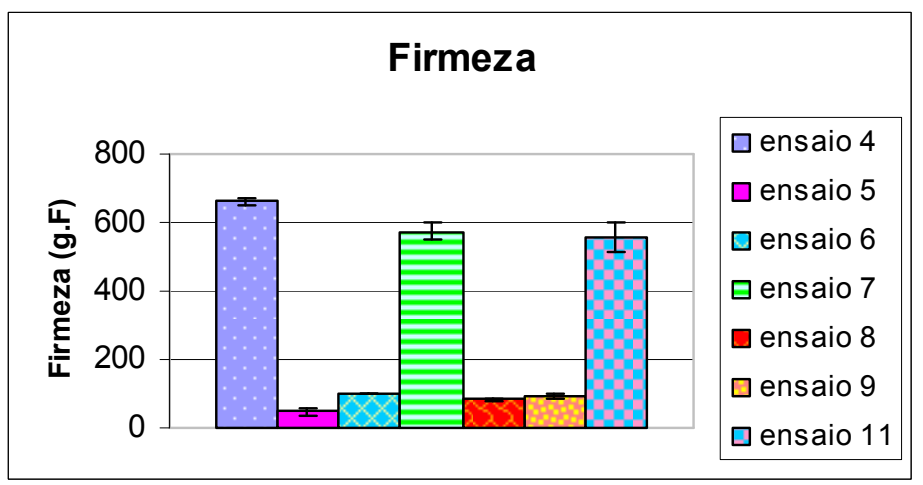

Figura 2 - Firmeza obtida para os ensaios-piloto 4, 5, 6, 7, 8, 9 e 11, após 1 dia de armazenamento dos produtos

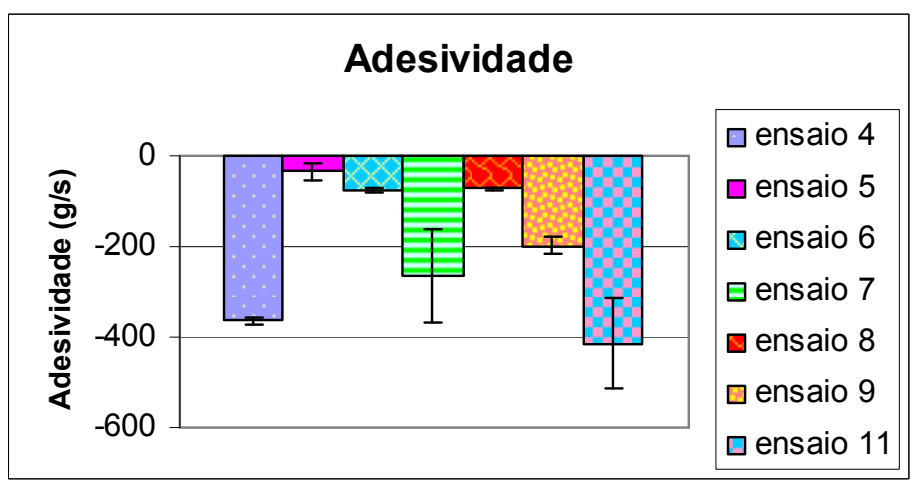

Figura 3 - Adesividade obtida para os ensaios-piloto 4, 5, 6, 7, 8, 9 e 11, após 1 dia de armazenamento dos produtos

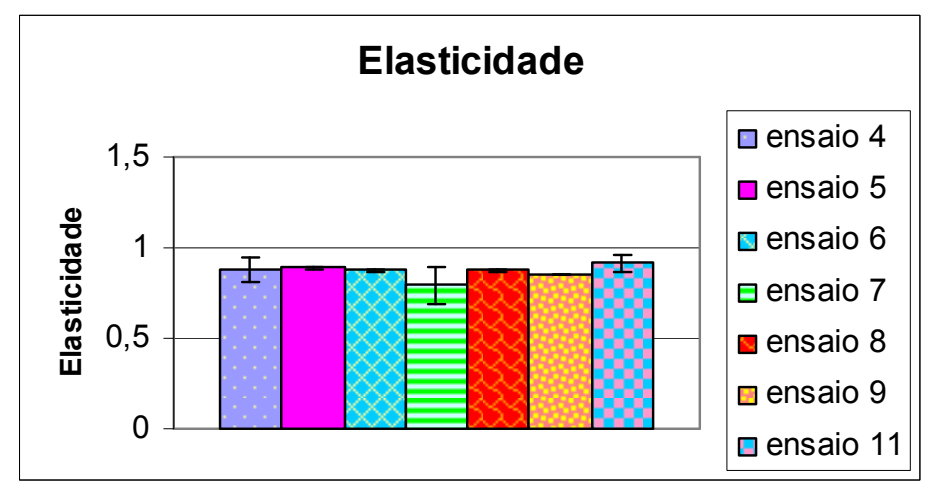

Figura 4 - Elasticidade obtida para os ensaios-piloto 4, 5, 6, 7, 8, 9 e 11, após 1dia de armazenamento dos produtos 


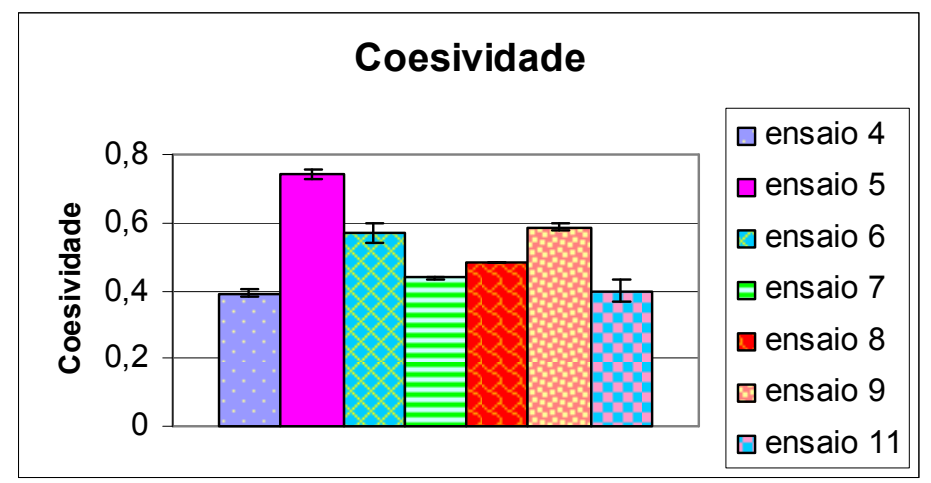

Figura 5 - Coesividade obtida para os ensaios-piloto 4, 5, 6, 7, 8, 9 e 11, após 1 dia de armazenamento dos produtos

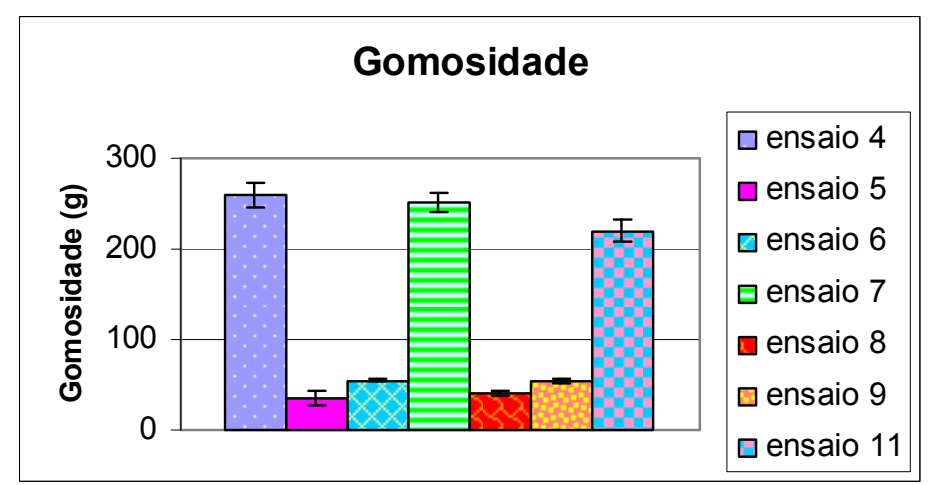

Figura 6 - Gomosidade obtida para os ensaios-piloto 4, 5, 6, 7, 8, 9 e 11, após 1 dia de armazenamento dos produtos

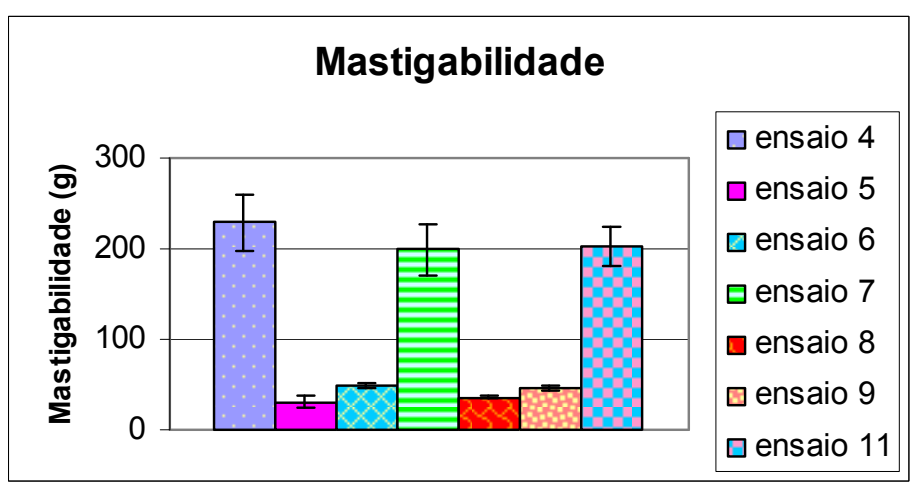

Figura 7 - Mastigabilidade obtida para os ensaios-piloto 4, 5, 6, 7, 8, 9 e 11, após 1 dia de armazenamento dos produtos

Os ensaios foram acompanhados desde o dia seguinte à fabricação e a cada 7 dias durante 28 dias, para se observar visualmente se havia dessora na embalagem e se avaliar a sua textura. 
O ensaio 4 apresentou textura pastosa, muito firme, embora tenha dessorado pouco. Já o ensaio 5 foi realizado na tentativa de se obter um manjar branco com textura menos firme. Este apresentou um produto de textura muito mole, com grumos e sabor prejudicado, ocorrendo grande dessora após 15 dias de armazenamento, não atendendo às características desejadas. No $6^{\circ}$ ensaio foi possível observar um produto com textura mais mole, porém sem grumos, brilhante e com ótimo sabor. Contudo, após 15 dias, este produto apresentou cor amarelada, textura bastante frágil e grande dessora, não atendendo às necessidades do produto. $O$ ensaio 7 apresentou textura satisfatória um dia depois à fabricação, porém ainda excessivamente consistente. Após 15 dias, observou-se pequena dessora e aumento na firmeza do produto. Já o $8^{\circ}$ ensaio apresentou textura mais mole e, após 15 dias, foi possível verificar grande dessora. O ensaio 11, por sua vez, apresentou um produto com cor amarelada intensa, maior dureza e muitos grumos, dessorando muito após 15 dias de armazenamento, não atendendo, portanto, às características de textura desejadas.

\subsubsection{Elaboração de manjar branco com a adição de goma xantana - Ensaio 10}

A este ensaio foi adicionada goma xantana, não adicionada nos ensaios anteriores, para se observar seu efeito na textura, sabor, aparência e aroma do manjar. Foram preparadas 10 amostras com $40 \mathrm{~g}$ cada. As proporções dos ingredientes utilizados na fabricação do manjar são apresentadas na Tabela 11. A tecnologia empregada na elaboração do manjar branco envolveu as etapas apresentadas na Figura 1.

Tabela 11 - Proporções dos ingredientes adicionados para a elaboração do manjar branco do ensaio-piloto 10

\begin{tabular}{cr}
\hline Ingredientes & \multicolumn{1}{c}{$\%$} \\
\hline leite & 73,59 \\
leite de coco & 16,35 \\
amido de milho & 4,09 \\
açúcar & 5,72 \\
goma xantana & 0,25 \\
\hline
\end{tabular}


Este ensaio não apresentou uma textura visivelmente característica de manjar branco. Desta forma as análises não foram conduzidas neste produto, devido ao seu alto grau de firmeza.

\subsubsection{Fabricação de manjar branco com a adição de coco ralado - Ensaio 12}

Este ensaio teve como objetivo adicionar coco ralado no processo de fabricação do manjar branco, com a finalidade de melhorar o sabor do produto final e diminuir sua dessoragem durante o armazenamento, mantendo-se a concentração dos demais ingredientes. Foram preparadas 10 amostras com $40 \mathrm{~g}$ cada. A tecnologia empregada na elaboração do manjar branco envolveu as etapas apresentadas na Figura 1. As proporções dos ingredientes utilizados na fabricação do manjar são apresentadas na Tabela 12.

Tabela 12 - Proporções dos ingredientes adicionados para a elaboração do manjar branco do ensaio-piloto 12

\begin{tabular}{cr}
\hline Ingredientes & \multicolumn{1}{c}{$\%$} \\
\hline leite & 72,46 \\
leite de coco & 16,10 \\
amido de milho & 4,03 \\
açúcar & 5,64 \\
coco ralado & 1,77 \\
\hline
\end{tabular}

Observou-se que a quantidade de coco ralado adicionada não foi suficiente para incrementar o sabor e evitar a ocorrência de dessoragem, motivando, no ensaio seguinte, o aumento da quantidade de coco ralado, em conjunto com a adição de goma para evitar dessora do produto durante o seu armazenamento refrigerado.

3.1.8 Elaboração de manjar branco com a adição de goma carragena e coco ralado - Ensaio 13

A goma carragena foi escolhida, neste ensaio, por ter apresentado um desempenho aceitável nos ensaios 4, 7, 8 e 11. As concentrações dos demais ingredientes com exceção do coco ralado foram mantidas. Foram preparadas 10 amostras com $40 \mathrm{~g}$ cada. A tecnologia empregada na elaboração do manjar branco 
envolveu as etapas apresentadas na Figura 1. As proporções dos ingredientes utilizados na fabricação do manjar são apresentadas na Tabela 13.

Tabela 13 - Proporções dos ingredientes adicionados para a elaboração do manjar branco do ensaio-piloto 13

\begin{tabular}{cr}
\hline Ingredientes & \multicolumn{1}{c}{$\%$} \\
\hline leite & 71,79 \\
leite de coco & 15,95 \\
amido de milho & 3,99 \\
açúcar & 5,58 \\
coco ralado & 2,39 \\
goma carragena & 0,30 \\
\hline
\end{tabular}

Foi realizada análise do perfil instrumental de textura conforme descrito no item 3.1.11.

O produto obtido no ensaio 13 apresentou pouca dessora, sua textura apresentou-se excelente, porém mascarou o sabor doce. Os parâmetros avaliados para textura após 15 dias de armazenamento apresentam-se na Tabela 14.

Tabela 14 - Parâmetros de textura obtidos para o manjar branco do ensaio 13

\begin{tabular}{crrrrrc}
\hline Teste & \multicolumn{5}{c}{ Firmeza } & \multicolumn{3}{c}{ Adesividade Elasticidade } & Cosividade & Gomosidade Mastigabilidade \\
\hline unidade & g.F & g.s s $^{-1}$ & & & $\mathrm{~g}$ & $\mathrm{~g}$ \\
1 & 456,453 & $-524,832$ & 0,955 & 0,400 & 182,642 & 174,423 \\
2 & 463,951 & $-331,489$ & 0,907 & 0,424 & 196,766 & 178,467 \\
3 & 436,852 & $-501,632$ & 0,955 & 0,444 & 193,884 & 185,159 \\
Média & 452,419 & $-452,651$ & 0,939 & 0,423 & 191,097 & 179,35 \\
Desvio-padrão & 11,425 & 86,196 & 0,023 & 0,018 & 6,093 & 4,427 \\
\hline
\end{tabular}

3.1.9 Elaboração de manjar branco com a adição de goma carragena e coco ralado - Ensaio 14

Neste ensaio foi aumentada a quantidade de açúcar utilizada, incrementando o sabor do manjar branco e a concentração da goma carragena foi mantida. Foram preparadas 10 amostras com $40 \mathrm{~g}$ cada. A tecnologia empregada na elaboração do manjar branco envolveu as etapas apresentadas na Figura 1. As proporções dos ingredientes utilizados na fabricação do manjar são apresentadas na Tabela 15. 
Foi realizada análise do perfil instrumental de textura, conforme descrito no item 3.1.11.

Tabela 15 - Proporções dos ingredientes adicionados no manjar branco do ensaiopiloto 14

\begin{tabular}{cc}
\hline Ingredientes & \multicolumn{1}{c}{$\%$} \\
\hline leite & 71,00 \\
leite de coco & 16,00 \\
amido de milho & 4,00 \\
açúcar & 6,30 \\
coco ralado & 2,40 \\
goma carragena & 0,30 \\
\hline
\end{tabular}

O produto obtido no ensaio 14 apresentou pouca dessora e sua textura mostrouse excelente, atendendo às características desejáveis para um manjar branco, como pouca dessora, cor branca, consistência mais firme e sabor e aroma característicos de coco. Os parâmetros avaliados encontrados apresentam-se na Tabela 16.

Tabela 16 - Parâmetros de textura obtidos para o manjar branco do ensaio 14

\begin{tabular}{|c|c|c|c|c|c|c|}
\hline Teste & Firmeza & Adesividade & Elasticidade & Coesividade & Gomosidade & Mastigabilidade \\
\hline unidade & g.F & g.s $\mathrm{s}^{-1}$ & & & $\mathrm{~g}$ & $\mathrm{~g}$ \\
\hline 1 & 397,994 & $-175,698$ & 0,959 & 0,414 & 164,779 & 158,023 \\
\hline 2 & 392,984 & $-350,110$ & 0,962 & 0,422 & 165,747 & 159,455 \\
\hline 3 & 412,485 & $-455,297$ & 0,889 & 0,426 & 175,534 & 156,049 \\
\hline Média & 401,154 & $-327,035$ & 0,937 & 0,420 & 168,687 & 157,843 \\
\hline Desvio-padrão & 8,269 & 115,306 & 0,034 & 0,005 & 4,858 & 1,396 \\
\hline
\end{tabular}

A produção de manjar branco mostrou-se apropriada para o emprego de microrganismos probióticos, como é possível observar pelos dados relativos aos ensaios 2 e 3, revelando populações superiores ao mínimo de $6-7$ log UFC/g proposto por LEE \& SALMINEN (1995) e HOIER et al. (1999), para a promoção de efeitos benéficos ao hospedeiro pelos alimentos probióticos.

A adição de goma carragena na proporção de 0,3\% mostrou-se bastante adequada para o processamento de manjar branco, apresentando bom efeito estabilizante, verificado durante os períodos de análise dos ensaios 13 e 14. A determinação das concentrações finais de cada ingrediente utilizado para a fabricação de manjar branco está relacionada no ensaio 14, na Tabela 15. 


\subsubsection{Armazenamento e períodos de amostragem}

O manjar foi armazenado sob refrigeração $\left(4 \pm 1^{\circ} \mathrm{C}\right)$. As análises microbiológicas, físico-químicas e de textura instrumental foram feitas no dia seguinte à fabricação (1 dia) e após 7, 14, 21 e 28 dias de armazenamento. As análises microbiológicas foram feitas em duplicata, análises físico-químicas em triplicata e para a determinação de textura instrumental foram realizadas de 5 a 8 repetições.

\subsubsection{Determinação da textura instrumental}

O perfil da textura (ensaios-piloto 2 a 11, 13 e 14) foi determinado em analisador de textura TA-XT2 (Stable Micro Systems, Haslemere, Inglaterra), empregando-se um cilindro de alumínio (P25) com base de $25 \mathrm{~mm}$. Foi realizado teste de dupla compressão, com velocidade de $1 \mathrm{~mm} / \mathrm{s}$, distância de $10 \mathrm{~mm}$ e tempo de $10 \mathrm{~s}$. Os parâmetros foram avaliados através do programa Texture Expert for Windows (Stable Micro Systems). O teste de textura utilizou os parâmetros pré-definidos para queijo cremoso por Buriti (2005).

\subsubsection{Determinação de parâmetros físico-químicos}

Decorridos os tempos de armazenamento sob refrigeração, descritos no item 3.1.10, foram feitas as determinações de:

- Umidade, a partir de $5 \mathrm{~g}$ de amostra em estufa a vácuo a $70^{\circ} \mathrm{C}$;

- $\mathrm{pH}$ em medidor de pH - Analyser Modelo 300M (Analyser Comércio e Indústria Ltda, São Paulo, Brasil) empregando-se um eletrodo tipo penetração modelo DME-CF (Analyser) para o ensaio 1.

\subsubsection{Determinação dos parâmetros microbiológicos}

Decorridos os tempos de armazenamento descritos no item 3.1.10 para cada um dos ensaios-pilotos, porções de $25 \mathrm{~g}$ de manjar (retiradas em condições de assepsia) foram homogeneizadas com $225 \mathrm{~mL}$ de água peptonada $0,1 \%$ (diluição $10^{-1}$ ), utilizando-se o Bag Mixer 400 (Interscience, St. Nom., França). Diluições decimais subseqüentes foram preparadas, utilizando o mesmo diluente.

Posteriormente, no manjar processado com a adição de Lactobacillus paracasei subsp. paracasei (LBC 82) (ensaios 1, 2 e 3), foi feita a contagem dessa bactéria 
probiótica. Para esse fim, alíquotas de $1 \mathrm{~mL}$ de cada diluição das amostras foram transferidas para placas de Petri estéreis. Em seguida, foi adicionado ágar MRS (Oxoid Ltd, Basingstoke, Reino Unido) acidificado a pH 5,4 com ácido acético glacial, fundido e resfriado a cerca de $45^{\circ} \mathrm{C}$ (semeadura em profundidade). Após a homogeneização e a solidificação do ágar, as placas foram incubadas em anaerobiose (Sistema de Anaerobiose Anaerogen, Oxoid) a $37^{\circ} \mathrm{C}$ por 72 horas (BURITI et al., 2005a).

\subsection{Ensaios definitivos}

\subsubsection{Elaboração do manjar branco}

A Figura 8 mostra, resumidamente, as principais etapas de fabricação dos ensaios definitivos realizados e apresentados neste trabalho. 


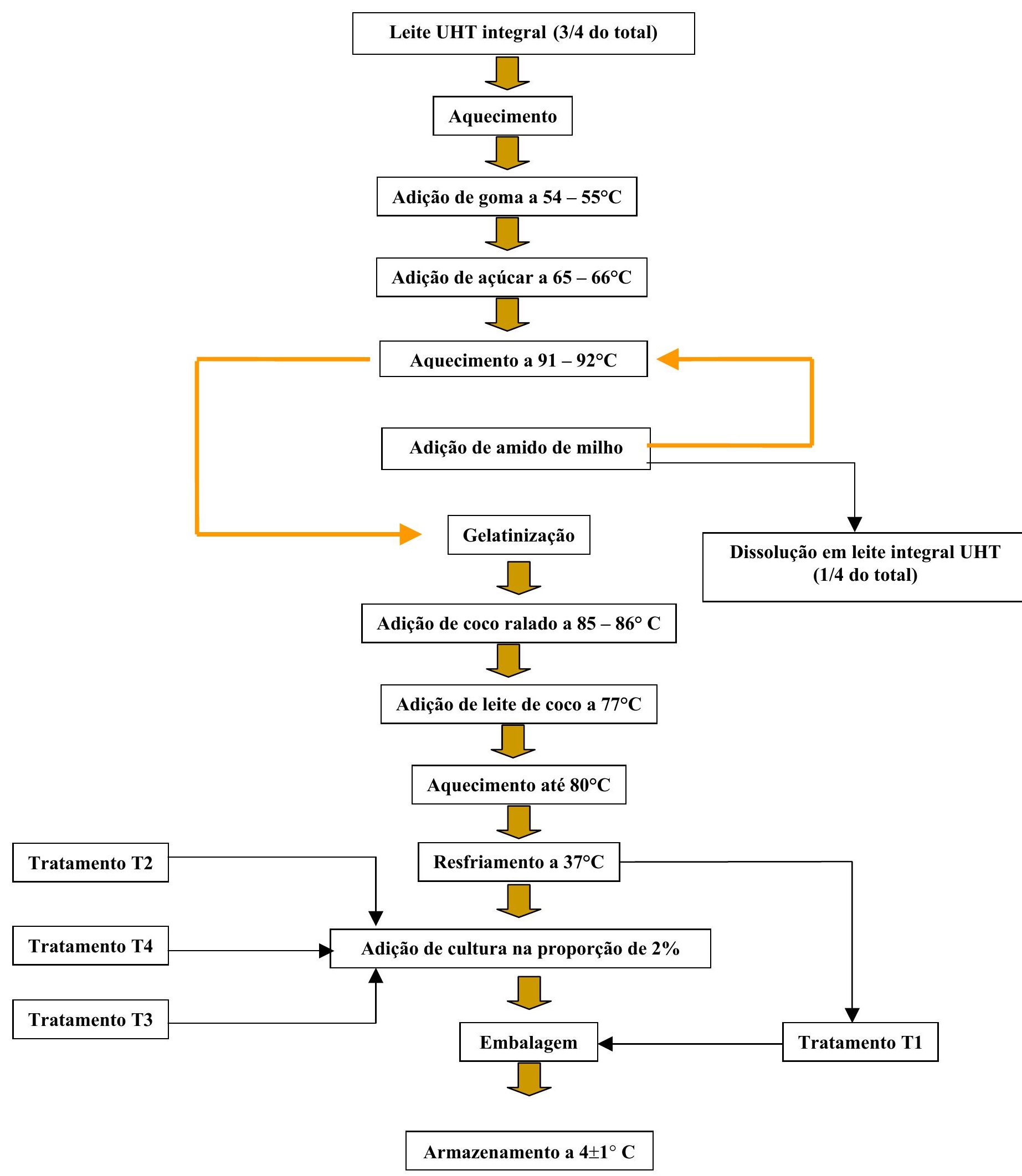

Figura 8 - Fluxograma contendo as principais etapas de elaboração do manjar branco nos ensaios definitivos conduzidos neste trabalho 
Apesar dos experimentos-piloto descritos no presente trabalho terem envolvido apenas a adição de L. paracasei subsp. paracasei, a adição de Bifidobacterium longum também foi testada. A produção de manjar branco mostrou-se apropriada para o emprego de L. paracasei subsp. paracasei e Bifidobacterium longum (dados não mostrados para esse último microrganismo), como foi possível observar através dos ensaios 2 e 3 . A adição de goma carragena na proporção de 0,3 \% mostrou-se bastante adequada para o processamento de manjar branco, apresentando bom efeito estabilizante, verificado durante os períodos de análise dos ensaios-piloto 13 e 14 .

A determinação das proporções finais de cada ingrediente utilizado para a fabricação de manjar branco nos ensaios definitivos está relacionada no ensaio 14 e consta na Tabela 15. Quatro tecnologias de produção de manjar branco foram testadas, envolvendo a não adição de cultura (controle - T1) e a adição das culturas individualmente (T2 e T3) ou associadas (T4), de acordo com as variáveis apresentadas na Tabela 17.

Tabela 17- Variáveis envolvidas na elaboração do manjar branco nos ensaios definitivos

\begin{tabular}{lcc}
\hline Tratamentos & L. paracasei $^{*}$ & B. longum $^{* *}$ \\
\hline T1 & - & - \\
T2 & - & + \\
T3 & + & - \\
T4 & + & + \\
\hline + = Adição. & - = Sem adição. \\
* Cultura potencialmente probiótica de Lactobacillus \\
paracasei subsp. paracasei (LBC 82, Danisco, Dangè, \\
France). \\
** Cultura potencialmente probiótica de Bifidobacterium \\
longum (BL-04 300 B, Danisco).
\end{tabular}

\subsubsection{Componentes químicos e culturas}

Os seguintes ingredientes comerciais foram empregados para a produção de manjar branco: leite integral esterilizado (Danone, São Paulo, SP, Brasil; 
temperatura ultra alta [UHT]), goma carragena LP-60 (CP Kelco, Limeira, SP, Brasil), açúcar (União, Coopersucar União, Limeira, SP, Brasil), amido de milho (Unilever, Mogi Guaçu, SP, Brasil), coco ralado (Ducôco, Itapipoca, CE, Brasil) e leite de coco (Ducôco, Itapipoca, CE, Brasil).

As culturas utilizadas foram de Bifidobacterium longum (BL-04 300 B, Danisco, Dangé, França) e Lactobacillus paracasei subsp. paracasei (LBC 82, Danisco), ambas do tipo DVS (Direct vat set- para adição direta) e foram fornecidas pelo fabricante na forma liofilizada, e armazenadas congeladas.

As proporções de ingredientes adicionados durante a produção do manjar branco para todos os tratamentos (T1, T2, T3 e T4) encontram-se descritas na Tabela 15.

\subsubsection{Produção do manjar branco}

As variáveis envolvidas na produção de manjar branco estão descritas na Tabela 17. Quatro tratamentos de manjar branco, denominados T1, T2, T3 e T4, foram realizados em triplicata (três repetições de cada tratamento foram produzidas em dias diferentes). O manjar branco T1 foi produzido sem a adição de culturas e foi usado como tratamento controle. O manjar branco T2 foi adicionado de Bifidobacterium longum BL-04 (300 B, Danisco) e o manjar branco T3 foi adicionado de Lactobacillus paracasei subsp. paracasei LBC 82 (Danisco). Ambas as culturas foram adicionadas como culturas individuais, enquanto o manjar branco T4 foi adicionado de BL-04 e LBC 82 em co-cultura. A adição das culturas à mistura foi realizada após uma etapa de pré-incubação em leite individualmente (T2 e T3) ou em co-cultura (T4). Para a realização dessa etapa de pré-incubação, 0,05 g de cada cultura liofilizada foram transferidas para $20 \mathrm{~mL}$ de leite, com incubação por 2 horas a $37^{\circ} \mathrm{C}$, previamente à adição no produto, com objetivo de se obter concentrações de no mínimo 7 log UFC/g no produto final.

Cada lote de manjar branco foi processado para se obter 2 a $3 \mathrm{~kg}$ de produto final. A produção de manjar branco foi realizada em um recipiente com capacidade para 4 $\mathrm{kg}$ de produto, onde $3 / 4$ do total de leite foi aquecido até $54-55^{\circ} \mathrm{C}$ e adicionado de goma carragena. A mistura foi, então, aquecida a $65-66^{\circ} \mathrm{C}$, quando o açúcar foi adicionado. Em seguida, a mistura foi aquecida até $91-92^{\circ} \mathrm{C}$, com subseqüente adição do amido de milho previamente diluído no leite restante (1/4). Neste ponto, a temperatura foi diminuída até $85-86^{\circ} \mathrm{C}$ e o coco ralado foi adicionado, desligando- 
se, em seguida, o aquecimento. Quando a temperatura da mistura atingiu $77^{\circ} \mathrm{C}$, o leite de coco foi adicionado. O aquecimento prosseguiu até a mistura alcançar a temperatura de $80^{\circ} \mathrm{C}$, quando se desligou novamente o aquecimento. No próximo passo, a mistura foi resfriada até $36-37^{\circ} \mathrm{C}$, as culturas foram, então, adicionadas e, após essa adição, a homogeneização do manjar branco foi realizada. O manjar branco foi acondicionado em potes plásticos, contendo $40 \mathrm{~g}$ de manjar cada, ocupando um volume médio de $5,0 \mathrm{~cm}^{3}$ em cada pote, selados com tampa de alumínio e armazenados a $4 \pm 1^{\circ} \mathrm{C}$, por 28 dias.

\subsubsection{Armazenamento e períodos de amostragem}

O manjar branco foi armazenado sob refrigeração $\left(4 \pm 1^{\circ} \mathrm{C}\right)$. As determinações dos parâmetros microbiológicos (duplicata), de textura (de 5 a 8 amostras por período) e dos demais parâmetros físico químicos (triplicata) das amostras foram feitas no dia seguinte à fabricação (1 dia) e após 7, 14, 21 e 28 dias de armazenamento. As determinações de gordura, proteínas e cinzas foram realizadas posteriormente, a partir de amostras congeladas, sendo utilizadas porções do produto final ( $1^{\circ}$ dia de armazenamento).

\subsubsection{Determinação da composição centesimal}

A determinação da composição centesimal do manjar branco foi feita em triplicata, a partir de amostras mantidas congeladas, exceto no caso da determinação da umidade (que foi monitorada durante todo o período de armazenamento do produto, conforme descrito no item 3.2.7).

Foram feitas as determinações de:

- gordura, através da extração de lipídios com éter etílico, em Soxhlet;

- proteínas, através de análise do conteúdo de nitrogênio pelo método micro-Kjeldahl, utilizando o fator de conversão 6,38; adaptado de ASSOCIATION OF OFFICIAL ANALYTICAL CHEMISTS (2000 a, b);

- cinzas, determinada gravimetricamente pela incineração de $2 \mathrm{~g}$ de amostra seca a $550^{\circ} \mathrm{C}$ até a eliminação completa de matéria orgânica. 
As determinações do teor de cinzas, de gordura e de proteínas foram realizadas de acordo com as normas do INSTITUTO ADOLFO LUTZ (1985). O teor de carboidratos foi calculado por diferença para se obter $100 \%$ da composição total.

As análises de gordura, proteína e cinzas foram efetuadas em triplicata, para cada uma das três repetições de cada tratamento.

\subsubsection{Determinação do perfil de textura instrumental}

O perfil de textura dos manjares T1, T2, T3 e T4 foi determinado através de teste de dupla compressão de amostras contidas nos recipientes plásticos (5 a 8 amostras de cada tratamento em cada período de análise), com peso constante, utilizando cilindro de alumínio de $25 \mathrm{~mm}$ de diâmetro (P25), em analisador de textura TA-XT2 (Stable Micro Systems, Haslemere, Reino Unido). Os dados foram coletados através do programa Texture Expert for Windows - versão 1.20 (Stable Micro Systems). Foram analisados os atributos firmeza, coesividade, adesividade, elasticidade e gomosidade. Foram empregados os seguintes parâmetros: amostras de manjar branco com $40 \mathrm{~g}$ e temperatura de $4 \pm 1^{\circ} \mathrm{C}$; distância e velocidade de compressão de $10 \mathrm{~mm}$ e de $1 \mathrm{~mm} / \mathrm{s}$, respectivamente; tempo de $10 \mathrm{~s}$. O perfil de textura foi acompanhado nos 5 ensaios dos manjares T1, T2, T3 e T4. A determinação do perfil instrumental de textura das amostras utilizou os parâmetros pré-definidos para queijo cremoso por Buriti (2005).

\subsubsection{Determinação dos parâmetros físico-químicos}

Decorridos os tempos de armazenamento sob refrigeração, descritos no item 3.2.4, foram feitas as determinações de:

- Umidade, a partir de $5 \mathrm{~g}$ de amostra em estufa a vácuo (Marconi MA030112) a $70{ }^{\circ} \mathrm{C}$;

- $\mathrm{pH}$, em medidor de pH - Analyser Modelo 300M (Analyser Comércio e Indústria Ltda., São Paulo, Brasil) empregando-se um Eletrodo tipo Penetração modelo DME-CF (Analyser). 
As análises de umidade e $\mathrm{pH}$ foram feitas em triplicata para cada tratamento e monitoradas durante todo o armazenamento do produto.

\subsubsection{Determinação dos parâmetros microbiológicos}

a) Viabilidade dos probióticos

A viabilidade de Bifidobacterium longum e de Lactobacillus paracasei subsp. paracasei foi monitorada, respectivamente, para os manjares T2 e T4 e para os manjares T3 e T4.

Para este propósito, decorridos os tempos de armazenamento, descritos no item 3.2.4., porções de $25 \mathrm{~g}$ de manjar branco (retiradas em condições de assepsia) foram homogeneizadas com $225 \mathrm{~mL}$ de água peptonada $0,1 \%$ (diluição $10^{-1}$ ), utilizando-se um Bag Mixer 400 (Interscience, St. Nom., França). Diluições decimais subseqüentes foram preparadas, utilizando o mesmo diluente.

No manjar processado com a adição de Bifidobacterium longum (T2 e T4) foi realizada a contagem dessa bactéria probiótica. Para esse fim, alíquotas de $1 \mathrm{~mL}$ de cada diluição das amostras foram transferidas para placas de Petri estéreis. Em seguida, foi adicionado ágar LP-MRS (De Man, Rogosa \& Sharpe, Oxoid, acrescido de $2 \%$ de cloreto de lítio e $3 \%$ de propionato de sódio), de acordo com VINDEROLA e REINHEIMER (1999). Assim, a semeadura das amostras foi feita em profundidade e as placas foram incubadas a $37^{\circ} \mathrm{C}$ por 3 dias em anaerobiose (Sistema de Anaerobiose Anaerogen, Oxoid).

Em virtude da possível interferência da presença de Lactobacillus paracasei na contagem de Bifidobacterium longum, para o manjar branco T4, a contagem de $B$. longum foi, paralelamente, realizada em ágar MRS modificado. Para esse fim, alíquotas de $1 \mathrm{~mL}$ de cada diluição das amostras foram transferidas para placas de Petri estéreis e em seguida foi adicionado ágar MRS modificado (Oxoid), adicionado de uma solução de dicloxalina $(0,5 \mathrm{mg} / \mathrm{L})$, cloreto de lítio $(1,0 \mathrm{~g} / \mathrm{L})$ e hidrocloridrato de cisteína (0,5 g/L), conforme descrito por ALEGRO (2003). Assim, a semeadura das amostras foi feita em profundidade e as placas foram incubadas a $37^{\circ} \mathrm{C}$ por 3 dias em anaerobiose (Sistema de Anaerobiose Anaerogen, Oxoid).

Para o manjar processado com a adição de Lactobacillus paracasei (T3 e T4), foi realizada a contagem dessa bactéria probiótica. Para esse fim, alíquotas de $1 \mathrm{~mL}$ de 
cada diluição das amostras foram transferidas para placas de Petri estéreis. Em seguida, foi adicionado ágar MRS (Oxoid, Ogdensburg, EUA) acidificado a pH 5,4 com ácido acético glacial, fundido e resfriado a cerca de $45^{\circ} \mathrm{C}$ (semeadura em profundidade). Após a homogeneização e a solidificação do ágar, as placas foram incubadas em anaerobiose (Sistema de Anaerobiose Anaerogen, Oxoid) a $37^{\circ} \mathrm{C}$ por 72 horas (BURITI et al., 2005 a).

b) Monitoramento de microrganismos contaminantes

Para o acompanhamento de microrganismos contaminantes alíquotas de $0,1 \mathrm{~mL}$ de cada diluição das amostras foram transferidas para placas contendo ágar BairdParker (base para ágar Baird-Parker, Oxoid, adicionado de telurito e gema de ovo suplemento SR054C, Oxoid), para a contagem de Staphylococcus spp. Alíquotas de $1 \mathrm{~mL}$ de cada diluição das amostras foram transferidas para placas de Petrifilm ${ }^{\mathrm{TM}}$ para Escherichia coli, denominadas Petrifilm ${ }^{\mathrm{TM}}$ EC (3M Microbiology, St. Paul, EUA), para a contagem de E.coli e de coliformes, de acordo com as instruções do fabricante. A incubação das placas de ágar Baird-Parker e de Petrifilm ${ }^{\mathrm{TM}} \mathrm{EC}$ foi feita a $35-37^{\circ} \mathrm{C}$ por 48 e por 24 horas, respectivamente.

Alíquotas de $1 \mathrm{~mL}$ de cada diluição das amostras foram transferidas para placas de Petrifilm ${ }^{T M}$ Yeasts and Moulds Count Plates (Petrifilm ${ }^{T M}$ YM, 3M Microbiology) e incubadas a $20-25^{\circ} \mathrm{C}$ por 5 dias, para a contagem de bolores e leveduras.

\subsubsection{Análise Sensorial}

A análise sensorial deste trabalho foi aprovada pelo Comitê de Ética em Pesquisa da Faculdade de Ciências Farmacêuticas da USP, conforme declaração constante no Anexo 1. A aceitabilidade de todos os tratamentos foi comparada após 7, 14 e 21 dias de armazenamento, empregando-se uma escala hedônica estruturada de nove pontos, onde a nota um é representada por "desgostei intensamente" e a nove por "gostei extremamente". A avaliação sensorial foi conduzida por vinte e quatro provadores não treinados da Universidade a cada período de armazenamento estudado (7, 14 e 21 dias), incluindo professores, alunos e técnicos, com idades na faixa de 18 a 54 anos e de ambos os sexos, selecionados com base em interesse e 
hábitos de consumo de manjar branco. Foram oferecidos, aproximadamente, $40 \mathrm{~g}$ de manjar em cada recipiente plástico, monadicamente, e foi solicitado aos provadores que avaliassem as amostras codificadas com três dígitos, relatando os atributos sensoriais que contribuíram para a escolha da amostra, com a finalidade de se obter maiores informações sobre as características sensoriais do produto. Um delineamento de blocos balanceados incompletos foi aplicado ( $t=4, k=2, \lambda=1, r=3$ ) neste trabalho, no qual cada provador avaliou duas amostras. Os provadores utilizaram água para limpar seus paladares entre as amostras e também foram instruídos a relatar qualquer observação sobre as características sensoriais das amostras de manjar branco (ex. sabor ácido ou azedo, textura pastosa ou aerada, aparência amarelada). Os blocos foram repetidos oito vezes, resultando em 24 repetições para cada amostra.

\subsubsection{Delineamento experimental e análise estatística}

O delineamento experimental foi inteiramente casualizado utilizando-se um planejamento fatorial $2^{2}$, constituído de 4 tipos de combinações (Lactobacillus paracasei, Bifidobacterium longum, L. paracasei + B. longum, controle) com intervalos de 5 tempos (1, 7, 14, 21 e 28 dias após o processamento) e 3 repetições (GOMES, 1987; BARROS NETO et al., 2003).

Exceto para a análise sensorial, a análise estatística dos ensaios definitivos foi realizada através de análise de variância (ANOVA), com utilização do teste de Tukey, considerando-se um nível de significância $\alpha<0,05$ (CALLEGARI-JACQUES, 2003).

Para a análise sensorial, inicialmente todas as variáveis foram avaliadas quanto à normalidade e homogeneidade da variância, através de gráficos de dispersão e testes de Hartley, Cochran e Barlett, respectivamente. Os valores foram expressos como média \pm desvio-padrão. Diferenças entre os quatro tratamentos durante o período de vida-de-prateleira foram avaliadas através de Análise de Variância com Medidas Repetidas e teste Tukey HSD. Análise de variância (ANOVA) foi aplicada ao delineamento fatorial $2^{2}$, a fim de avaliar o efeito de interação ao final da vida-deprateleira. Um valor $p<0,05$ foi considerado significante. As análises estatísticas para 
análise sensorial foram realizadas, utilizando-se o pacote estatístico Statistica (versão 6.1, Statsoft, Tulsa, OK, USA).

\section{RESULTADOS E DISCUSSÃO}

\subsection{Ensaios definitivos}

\subsubsection{Composição centesimal}

Os teores médios de gordura, proteína, cinzas e carboidratos totais obtidos para os manjares T1, T2, T3 e T4, após 1 dia de fabricação são apresentados na tabela 18.

Tabela 18 - Teores médios* de gordura, proteína, cinzas e carboidratos totais obtidos para os manjares T1, T2, T3 e T4 no produto final - extrato seco (ES) e matéria úmida (MU) - após 1 dia de armazenamento sob refrigeração a $4 \pm 1^{\circ} \mathrm{C}$ (ver Tabela 17 para a descrição de T1, T2, T3 e T4)

\begin{tabular}{|c|c|c|c|c|}
\hline & \multicolumn{4}{|c|}{ Manjar branco } \\
\hline & T1 & T2 & T3 & T4 \\
\hline$\%$ & $15,76^{\mathrm{A}}(0,47)$ & $14,30^{\mathrm{AB}}(1,07)$ & $16,83^{\mathrm{C}}(0,19)$ & $\overline{14,00^{\mathrm{B}}(0,79)}$ \\
\hline Gordura MU\% & $4,51^{\mathrm{A}}(0,13)$ & $4,09^{\mathrm{AB}}(0,30)$ & $4,81^{\mathrm{C}}(0,05)$ & $4,00^{\mathrm{B}}(0,22)$ \\
\hline roteína ES\% & $11,48^{\mathrm{A}}(0,21)$ & $11,73^{\mathrm{A}}(0,19)$ & $11,77^{\mathrm{A}}(0,44)$ & $11,46^{\mathrm{A}}(0,52)$ \\
\hline roteína MU\% & $3,28^{\mathrm{A}}(0,06)$ & $3,35^{\mathrm{A}}(0,06)$ & $3,37^{\mathrm{A}}(0,13)$ & $3,28^{\mathrm{A}}(0,15)$ \\
\hline Cinzas ES\% & $9,10^{\mathrm{BC}}(0,14)$ & $9,12^{\mathrm{C}}(0,13)$ & $8,80^{\mathrm{AB}}(0,13)$ & $8,79^{\mathrm{A}}(0,07)$ \\
\hline Cinzas MU\% & $2,60^{\mathrm{BC}}(0,04)$ & $2,61^{\mathrm{C}}(0,04)$ & $2,52^{\mathrm{AB}}(0,13)$ & $2,51^{\mathrm{A}}(0,07)$ \\
\hline Carboidratos totais ES\% & $63,66^{\mathrm{AB}}(0,54)$ & $64,85^{\mathrm{BC}}(0,79)$ & $62,60^{\mathrm{A}}(0,64)$ & $65,76^{\mathrm{C}}(0,82)$ \\
\hline Carboidratos totais MU\% & $18,19^{\mathrm{AB}}(0,15)$ & $18,53^{\mathrm{BC}}(0,23)$ & $17,88^{\mathrm{A}}(0,18)$ & $18,79^{\mathrm{C}}(0,23)$ \\
\hline \multicolumn{5}{|c|}{$\begin{array}{l}\text { * valores médios de triplicatas de } 3 \text { ensaios (repetições) de cada manjar branco (com } \\
\text { desvio-padrão entre parêntesis). } \\
\text { A, B sobrescritas distintas na mesma linha indicam diferenças significativas }(p<0,05) \text { entre os } \\
\text { diferentes tratamentos. }\end{array}$} \\
\hline \multicolumn{5}{|c|}{$\begin{array}{l}\text { Houve grande variação no teor de gordura entre os tratamentos T1, T2, T3 e T4, } \\
\text { sultando em um desvio-padrão elevado desse parâmetro para todos os } \\
\text { atamentos (tabela 18). Acredita-se que tenham ocorrido oscilações no teor de } \\
\text { rdura do coco ralado e do leite de coco utilizados, implicando, possivelmente, em }\end{array}$} \\
\hline
\end{tabular}


proteínas e cinzas) devido, provavelmente, a diferenças entre os diferentes lotes de matéria-prima utilizados. É necessário destacar que todos os ingredientes utilizados para a produção dos manjares deste trabalho sempre pertenceram ao mesmo fabricante.

\subsubsection{Parâmetros microbiológicos - microrganismos probióticos}

A Tabela 19 mostra a evolução das populações médias de Bifidobacterium longum durante o armazenamento refrigerado de manjar branco para os manjares T2 e T4 e as populações mínimas e máximas obtidas para todas as amostras analisadas.

Tabela 19 - Viabilidade de Bifidobacterium spp. nos manjares brancos T2 (em ágar LP-MRS) e T4 (em ágar LP-MRS e em ágar MRS modificado) durante o armazenamento a $4 \pm 1^{\circ} \mathrm{C}$ e populações mínimas e máximas obtidas para todas as amostras analisadas (veja Tabela 17 para descrição de T2 e T4)

\begin{tabular}{|c|c|c|c|c|c|c|}
\hline \multirow{4}{*}{ Dias } & \multicolumn{6}{|c|}{ População de Bifidobacterium spp. (log UFC/g) } \\
\hline & \multicolumn{6}{|c|}{ Tratamentos } \\
\hline & \multicolumn{2}{|c|}{$\mathrm{T} 2^{* * *}$} & \multicolumn{2}{|c|}{$\mathrm{T} 4^{* * *}$} & \multicolumn{2}{|c|}{$\mathrm{T} 4^{\star * \star *}$} \\
\hline & Média * & Variação** & Média * & Variação** & Média * & Variação** \\
\hline 1 & $7,46^{\mathrm{Ba}}(0,06)$ & $7,37-7,54$ & $7,23^{\mathrm{Aa}}(0,03)$ & $7,18-7,27$ & $7,21^{\mathrm{Aa}}(0,10)$ & $7,07-7,36$ \\
\hline 7 & $7,46^{\mathrm{Ba}}(0,06)$ & $7,38-7,53$ & $7,41^{\mathrm{Bb}}(0,04)$ & $7,37-7,47$ & $7,34^{\mathrm{Ab}}(0,03)$ & $7,30-7,39$ \\
\hline 14 & $7,41^{\mathrm{Aab}}(0,03)$ & $7,36-7,45$ & $7,41^{\mathrm{Ab}}(0,07)$ & $7,32-7,48$ & $7,36^{\mathrm{Ab}}(0,08)$ & $7,26-7,46$ \\
\hline 21 & $7,41^{\mathrm{Cab}}(0,09)$ & $7,28-7,52$ & $7,27^{\mathrm{Aa}}(0,06)$ & $7,20-7,32$ & $7,15^{\mathrm{Ba}}(0,02)$ & $7,10-7,17$ \\
\hline 28 & $7,36^{\mathrm{Bb}}(0,05)$ & $7,30-7,41$ & $7,26^{\mathrm{Aa}}(0,09)$ & $7,13-7,30$ & $7,17^{\mathrm{Aa}}(0,08)$ & $7,06-7,27$ \\
\hline \multicolumn{7}{|c|}{$\begin{array}{l}\text { * Médias (com desvio-padrão entre parêntesis) } \\
\text { ** Mínima - máxima populações obtidas para todas as amostras analisadas } \\
{ }^{\star * *} \text { ágar LP-MRS } \\
\text { a** ágar MRS modificado } \\
\text { a, b sobrescritas minúsculas distintas, para cada tratamento, indicam diferenças significativas } \\
(p<0,05) \text { entre os diferentes dias de armazenamento. }\end{array}$} \\
\hline
\end{tabular}

O manjar branco T2 apresentou diminuição significativa $(p<0,05)$ da população de Bifidobacterium somente após 28 dias de armazenamento (Tabela 19). Para ambos os meios de cultura utilizados, Bifidobacterium spp. atingiu populações mais elevadas ao $7^{\circ}$ e ao $14^{\circ}$ dia, principalmente para $\mathrm{T} 4$, com aumento significativo 
durante a primeira semana de armazenamento $(p<0,05)$, diminuindo significativamente após 21 dias de armazenamento para T4 $(p<0,05)$ (Tabela 19). Entretanto, deve ser ressaltado que os aumentos significativos observados são pouco representativos, do ponto de vista microbiológico.

A Tabela 20 mostra a evolução das populações médias de Lactobacillus spp. durante o armazenamento refrigerado dos manjares T3 e T4. Ambos os manjares (T3 e T4) apresentaram populações médias ao redor de 6,5 log UFC/g durante o primeiro dia e um aumento nas populações durante todo o armazenamento; as populações obtidas foram significativamente mais elevadas para T3 a partir de 7 dias de armazenamento $(p<0,05)$. Um aumento significativo $(p<0,05)$ nas populações de L. paracasei durante todos os dias de armazenamento avaliados foi observado para o manjar branco T3, enquanto que para T4 um aumento significativo das populações foi observado apenas a partir de 21 dias de armazenamento (Tabela 20).

Tabela 20 - Viabilidade de Lactobacillus spp. nos manjares brancos T3 e T4 durante o armazenamento a $4 \pm 1{ }^{\circ} \mathrm{C}$ e populações mínimas e máximas obtidas para todas as amostras analisadas (veja Tabela 17 para descrição de T3 e T4)

\begin{tabular}{|c|c|c|c|c|}
\hline \multirow{4}{*}{ Dias } & \multicolumn{4}{|c|}{ População de Lactobacillus spp. (log UFC/g) } \\
\hline & \multicolumn{4}{|c|}{ Tratamentos } \\
\hline & \multicolumn{2}{|c|}{ T3 } & \multicolumn{2}{|c|}{ T4 } \\
\hline & Média * & Variação** & Média * & Variação** \\
\hline 1 & $6,60^{\mathrm{Aa}}(0,09)$ & $6,49-6,70$ & $6,42^{\mathrm{Aa}}(0,14)$ & $6,26-6,54$ \\
\hline 7 & $7,15^{\mathrm{Bb}}(0,10)$ & $7,04-7,27$ & $6,45^{\mathrm{Aa}}(0,08)$ & $6,32-6,54$ \\
\hline 14 & $7,37^{\mathrm{Bc}}(0,05)$ & $7,30-7,42$ & $6,53^{\mathrm{Aa}}(0,12)$ & $6,43-6,76$ \\
\hline 21 & $8,37^{\mathrm{Bd}}(0,05)$ & $8,30-8,43$ & $6,87^{\mathrm{Ab}}(0,03)$ & $6,81-6,91$ \\
\hline 28 & $8,64^{\mathrm{Be}}(0,08)$ & $8,51-8,72$ & $7,33^{\mathrm{Ac}}(0,21)$ & $7,03-7,56$ \\
\hline \multicolumn{5}{|c|}{$\begin{array}{l}\text { * Médias (com desvio-padrão entre parêntesis). } \\
\text { ** Mínima - máxima contagem obtidas para todas as amostras } \\
\text { analisadas. } \\
\text { a, b sobrescritas minúsculas distintas, para cada tratamento, } \\
\text { indicam diferenças significativas }(p<0,05) \text { entre os diferentes dias } \\
\text { de armazenamento. } \\
\text { A, B, C sobrescritas maiúsculas distintas, na mesma linha, indicam } \\
\text { diferenças significativas }(p<0,05) \text { entre os diferentes tratamentos. }\end{array}$} \\
\hline
\end{tabular}

Os alimentos probióticos encontraram grande aceitação por parte dos consumidores (HEENAN et al., 2004). A produção de alimentos contendo cepas probióticas específicas em concentrações apropriadas de células viáveis durante a 
vida-de-prateleira é um desafio tecnológico (KOURKOUTAS et al., 2005). Vários trabalhos propõem uma dose terapêutica mínima diária de $10^{8}-10^{9} \mathrm{UFC} / \mathrm{g}$, o que corresponde ao consumo diário de $100 \mathrm{~g}$ de produto contendo $10^{6}$ a $10^{7} \mathrm{UFC} / \mathrm{g}$ para que os alimentos probióticos possam oferecer benefícios para saúde (LEE \& SALMINEN, 1995; BLANCHETTE et al., 1996; HOIER et al., 1999).

Desse modo, o manjar branco apresentou-se como um veículo extremamente promissor, com grande potencial probiótico para ambas as cepas testadas, quando comparados com produtos probióticos descritos na literatura, devido a suas altas populações de microrganismos probióticos e seu pH próximo do neutro.

Diversos estudos vêm sendo recentemente conduzidos, no sentido de testar o desempenho de diversas culturas probióticas para a produção de diferentes produtos, entre os quais podem ser destacados vários tipos de queijos. Vinderola et al. (2000b) relataram um estudo com queijo fresco, no qual culturas probióticas concentradas de bifidobacteria, $L$. casei e $L$. acidophilus foram adicionadas simultaneamente com os starters Streptococcus thermophilus e Lactococcus lactis para se avaliar as interações entre os probióticos e as bactérias starter. Bifidobacteria e $L$. casei foram enumerados em LP-MRS ágar em anaerobiose a $37^{\circ} \mathrm{C}$. Os autores observaram que as populações das espécies de bifidobacteria diminuíram 1 ciclo log durante o período de armazenamento de 60 dias, mantendo, porém, populações acima de $10^{6} \mathrm{UFC} / \mathrm{g}$. A viabilidade de bifidobacteria foi, também, estimulada pela presença de outra bactéria probiótica, resultando em maior população de todas as bactérias avaliadas. No presente trabalho, quando $B$. longum foi adicionado em co-cultura com L. paracasei (T4) durante a produção de manjar branco, a população de $B$. longum permaneceu semelhante quando adicionado como uma cultura isolada (T2), para ambos os meios de cultura empregados. Por outro lado, a população de Lactobacillus paracasei foi favorecida, quando o microrganismo foi adicionado isoladamente. Portanto, a interação favorável ou protocooperação provavelmente não ocorreu entre as cepas de $B$. longum e $L$. paracasei no manjar branco T4.

Buriti et al. (2005a) testaram a mesma cepa de L. paracasei subsp. paracasei (LBC 82) utilizada no presente trabalho, em queijo minas frescal. Os autores relataram populações de $L$. paracasei sempre acima de $10^{6}-10^{7}$ UFC/g nos queijos. Similarmente ao que foi observado neste trabalho, Heenan et al. (2004), em um estudo com sobremesa gelada vegetariana não fermentada, adicionada de $L$. 
paracasei subsp. paracasei, B. lactis e L. rhamnosus, observaram que todas as culturas sobreviveram durante os 6 meses de armazenamento, com populações iguais ou maiores que $10^{7} \mathrm{UFC} / \mathrm{g}$. No presente trabalho, as populações de $L$. paracasei obtidas para os manjares T3 e T4 foram ligeiramente superiores que aquelas obtidas para $B$. longum (T2 e T4), especialmente para os manjares T3, nos quais populações entre 8,30 e 8,72 UFC/g foram alcançadas após 21 dias de armazenamento.

Uysal et al. (2003), em estudo com iogurte produzido com leites caprino e bovino adicionados de $L$. acidophilus, B. bifidum e $S$. thermophilus, observaram que nem o método de concentração, nem o tipo de leite afetavam a concentração de microrganismos $(p>0,05)$, mas diferenças significativas foram encontradas durante 0 período de armazenamento $(p<0,05)$. Os autores relataram que as populações de $B$. bifidum diminuíram 6 a 8 log UFC/g ao $14^{\circ}$ dia de armazenamento, de acordo com o tipo de tratamento e leite, enquanto $L$. acidophilus teve uma ligeira diminuição de 3 a $5 \log$ UFC/g ao $14^{\circ}$ dia de armazenamento. No presente trabalho, B. longum manteve-se sempre entre os valores recomendados $\left(10^{6}-10^{7} \mathrm{UFC} / \mathrm{g}\right)$ ou acima, no manjar branco T2 e T4, durante todo o período de armazenamento, e populações ligeiramente maiores foram alcançadas quando o probiótico foi adicionado isoladamente (T2). Isso demonstra que o manjar branco é um excelente veículo para probióticos, onde $\mathrm{o} \mathrm{pH}$ próximo ao neutro aliado a uma temperatura de armazenamento de $4 \pm 1^{\circ} \mathrm{C}$ ajudou a promover a multiplicação de microrganismos probióticos.

Bifidobacterium longum e B. bifidum estão entre as cepas que demonstram boa viabilidade durante o processamento e armazenamento de diversos tipos de queijos (BOYLSTON et al., 2004). Corbo et al. (2001) compararam também a viabilidade de $B$. longum e $B$. bifidum em queijo duro italiano. Durante os 35 dias de maturação, as duas espécies mostraram viabilidade similar, com populações de $10^{7} \mathrm{UFC} / \mathrm{g}$ durante os 19 dias de maturação, decrescendo para $10^{6}$ UFC/g com 35 dias de maturação. Entretanto, após 56 dias de maturação, as populações de $B$. longum obtidas pelos autores diminuíram para $10^{5} \mathrm{UFC} / \mathrm{g}$. No presente trabalho, o manjar branco apresentou viabilidade similar, com populações de $B$. longum de $10^{7} \mathrm{UFC} / g$ durante os 28 dias de armazenamento. 
4.1.3 Parâmetros microbiológicos - microrganismos indicadores de contaminação

A Tabela 21 mostra as populações de coliformes totais (médias de 3 ensaios) obtidas para os manjares T1, T2, T3 e T4 durante os 28 dias de armazenamento sob refrigeração a $4 \pm 1^{\circ} \mathrm{C}$.

A presença de coliformes totais foi observada no manjar T2 somente ao $7^{\circ}$ dia, enquanto que no manjar T3 esses microrganismos foram observados ao $7^{\circ}, 21^{\circ} \mathrm{e}$ $28^{\circ}$ dias de armazenamento (Tabela 21). Não foram detectadas populações de coliformes durante o armazenamento para os manjares T1 e T4. Escherichia coli não foi detectada em nenhuma das amostras coletadas durante o armazenamento de 3 ensaios dos manjares T1, T2, T3 e T4. Foram detectadas populações médias de coliformes de $2 \log$ para os manjares T3 nos dias 7, 21 e 28 e para o manjar T2 ao $7^{\circ}$ dia (Tabela 21).. A legislação para sobremesas lácteas, estabelece limites apenas para coliformes a $45^{\circ} \mathrm{C}$ - máximo $10^{2} / \mathrm{g}$ (ANVISA, 2001).

Tabela 21 - Populações médias de coliformes totais nos manjares brancos T1, T2, T3 e T4 durante o armazenamento a $4 \pm 1^{\circ} \mathrm{C}$ e populações mínimas e máximas obtidas para todas as amostras analisadas (veja Tabela 17 para descrição de T3 e T4)

\begin{tabular}{|c|c|c|c|c|c|c|c|c|}
\hline \multirow[b]{3}{*}{ Dias } & \multicolumn{8}{|c|}{ Coliformes (log UFC/g) } \\
\hline & \multicolumn{2}{|r|}{$\mathrm{T1}$} & \multicolumn{2}{|r|}{$\mathrm{T} 2$} & \multicolumn{2}{|c|}{ T3 } & \multicolumn{2}{|r|}{$\mathrm{T} 4$} \\
\hline & Média & Variação** & Média & Variação** & Média & Variação** & Média & Variação** \\
\hline 1 & $<1$ & - & $<1$ & - & $<1$ & - & $<1$ & - \\
\hline 7 & $<1$ & - & $2,61^{*}$ & $<1-2,80$ & $2,75^{*}$ & $<1-2,76$ & $<1$ & - \\
\hline 14 & $<1$ & - & $<1$ & - & $<1$ & - & $<1$ & - \\
\hline 21 & $<1$ & - & $<1$ & - & $2,65^{*}$ & $<1-2,72$ & $<1$ & - \\
\hline 28 & $<1$ & - & $<1$ & - & $2,49 *$ & $<1-3,04$ & $<1$ & - \\
\hline
\end{tabular}

A Tabela 22 mostra as populações de Staphylococcus spp. (médias de 3 ensaios) obtidas para os manjares T1, T2, T3 e T4 durante os 28 dias de armazenamento sob refrigeração a $4 \pm 1^{\circ} \mathrm{C}$.

Staphylococcus spp. foram detectados nas amostras dos manjares T1, T2, T3 e T4, com populações médias obtidas ao longo do armazenamento entre $<2$ e 2,7 log 
UFC/g para o manjar T1, entre 2 e 2,7 log UFC/g para o manjar branco T2, entre <2 e 2,8 log UFC/g para o manjar T3 e entre <2 e 2,3 log UFC/g para o manjar T4. Possivelmente a presença de $L$. paracasei no manjar branco T3 e T4 atuou na inibição de Staphylococcus spp., uma vez que os valores máximos de populações encontrados foram inferiores para os manjares T3 e T4, quando comparadas com T1 e T2 (Tabela 22).

A inibição de microrganismos contaminantes por bactérias láticas tem sido bastante estudada. Arici et al. (2004) estudaram a atividade de diferentes cepas de Lactobacillus spp., isoladas de fezes de crianças, entre recém nascidos e até dois anos de idade, sobre bactérias contaminantes de alimentos ou patógenos. Os autores verificaram que 4 cepas de Lactobacillus paracasei (IF8, IF9, IF10 e IF11) exerceram efeito inibitório sobre Staphylococcus aureus ATCC 28213 e 3 cepas (IF8, IF10 e IF11) inibiram a multiplicação de Staphylococcus aureus ATCC 2392, em ensaios de difusão em ágar.

Tabela 22 - Populações médias de Staphylococcus spp. nos manjares brancos T1, T2, T3 e T4 durante o armazenamento a $4 \pm 1^{\circ} \mathrm{C}$ e populações mínimas e máximas obtidas para todas as amostras analisadas (veja Tabela 17 para descrição de T3 e T4)

\begin{tabular}{|c|c|c|c|c|c|c|c|c|}
\hline & \multicolumn{8}{|c|}{ Staphylococcus spp. (log UFC/g) } \\
\hline & \multicolumn{2}{|r|}{$\mathrm{T} 1$} & \multicolumn{2}{|r|}{ T2 } & \multicolumn{2}{|c|}{ T3 } & \multicolumn{2}{|r|}{ T4 } \\
\hline & Média & Variação** & Média & Variação** & Média & Variação** $^{* *}$ & Média & Variação** \\
\hline \multicolumn{9}{|c|}{ Dias } \\
\hline 1 & $<2$ & - & $2,00^{*}$ & $<2-2,00$ & $<2$ & - & $<2$ & - \\
\hline 7 & $2,66^{*}$ & $<2-2,85$ & $2,00^{*}$ & $<2-2,00$ & $<2$ & - & $2,26^{*}$ & $<2-2,48$ \\
\hline 14 & $2,36^{*}$ & $<2-2,60$ & $2,31^{*}$ & $<2-2,48$ & $2,15^{*}$ & $<2-2,30$ & $<2$ & - \\
\hline 21 & $2,59^{*}$ & $<2-2,78$ & $2,71^{*}$ & $<2-2,85$ & $2,77^{*}$ & $<2-2,85$ & $<2$ & - \\
\hline 28 & $2,63^{*}$ & $<2-2,78$ & $2,49^{*}$ & $<2-2,78$ & $2,00^{*}$ & $<2-2,00$ & $<2$ & - \\
\hline
\end{tabular}

Foram encontrados bolores e leveduras para os manjares T2 e T3 apenas ao $28^{\circ}$ dia, enquanto que, para o manjar T4, esses contaminantes foram detectados ao $21^{\circ}$ e $28^{\circ}$ dias. No manjar branco T1, não foi detectada a presença de bolores e leveduras durante todo o armazenamento (Tabela 23). É mais provável que o 
aparecimento desses microrganismos durante o armazenamento do manjar branco tenha sido decorrente da sua presença no ambiente durante a fabricação. De qualquer modo, as populações de bolores e leveduras estiveram abaixo do limite estabelecido pela legislação (Brasil, 1997) durante o armazenamento dos manjares produzidos neste trabalho.

Todos os manjares produzidos para o presente trabalho foram elaborados de acordo com as boas práticas de fabricação, havendo amplo controle de higiene dos utensílios empregados e da manipulação das matérias-primas e do manjar branco durante todo o processamento.

Tabela 23 - Populações médias de bolores e leveduras nos manjares brancos T1, T2, T3 e T4 durante o armazenamento a $4 \pm 1^{\circ} \mathrm{C}$ e populações mínimas e máximas obtidas para todas as amostras analisadas (veja Tabela 17 para descrição de T3 e T4)

\begin{tabular}{ccccccccc}
\hline & \multicolumn{8}{c}{ Bolores e leveduras (log UFC/g) } \\
\cline { 2 - 9 } & \multicolumn{9}{c}{ T1 } & \multicolumn{9}{c}{ T2 } & \multicolumn{3}{c}{ T3 } & \multicolumn{1}{c}{ T4 } \\
\cline { 2 - 9 } Dias & Média & Variação** & Média & Variação** & Média & Variação** & Média & Variação** \\
\hline 1 & $<1$ & - & $<1$ & - & $<1$ & - & $<1$ & - \\
7 & $<1$ & - & $<1$ & - & $<1$ & - & $<1$ & - \\
14 & $<1$ & - & $<1$ & - & $<1$ & - & $<1$ & - \\
21 & $<1$ & - & $<1$ & - & $<1$ & - & $1,43^{*}$ & $<1-1,60$ \\
28 & $<1$ & - & $1,22^{*}$ & $<1-1,47$ & $1,90^{*}$ & $<1-1,95$ & $1,87^{*}$ & $<1-1,95$ \\
\hline
\end{tabular}

* Médias para as amostras positivas

**Valores mínimos - máximos das populações obtidas para todas as amostras analisadas.

- = Sem variação.

\subsubsection{Parâmetros físico-químicos}

A Tabela 24 mostra a evolução dos parâmetros físico-químicos dos manjares controle - T1, adicionados de B. longum - T2, adicionados de L. paracasei - T3 e adicionados de $B$. longum e $L$. paracasei - T4 durante o armazenamento refrigerado.

O manjar branco T3 apresentou valores de pH significativamente mais baixos $(p<0,05)$ durante o armazenamento, quando comparado a T1, T2 e T4. Por outro lado, o manjar T4 apresentou valores de $\mathrm{pH}$ significativamente mais altos nos dias 1 e 7, comparados com T1, T2 e T3 $(p<0,05)$. A umidade dos manjares T1, T2, T3 e 
T4 não apresentou diferenças significativas $(p>0,05)$ entre os tratamentos e entre os diferentes dias de armazenamento para cada tratamento (Tabela 24, Figura 10).

Lankaputra e Shah (1995), em estudo sobre a sobrevivência de nove cepas de Bifidobacterium spp. sob condições ácidas ( $\mathrm{pH} 1,5-3,0)$, concluíram que $B$. longum e $B$. pseudolongum sobrevivem melhor em condições ácidas do que $B$. bifidum. Mais recentemente, Reilly e Gilliland (1999) avaliaram a sobrevivência de quatro cepas de $B$. longum durante sua multiplicação, com relação ao $\mathrm{pH}$, e observaram que uma das cepas, B. longum S9, era mais estável do que as outras durante o armazenamento do produto. De modo geral, a maioria das cepas de bifidobacteria é sensível a valores de $\mathrm{pH}$ abaixo de 4,6. Além do mais, para uma aplicação prática, o valor de $\mathrm{pH}$ do produto final deve der mantido acima de 4,6 para evitar a diminuição da população de bifidobacterias (TAMINE et al., 1985; MODLER et al., 1990; LAROIA et al., 1991a). Os valores de pH obtidos para o manjar branco no presente estudo são relativamente altos, próximos ao neutro, possivelmente permitindo uma maior multiplicação de Bifidobacterium longum. De modo semelhante, Heenan et al. (2004), em estudo com sobremesa gelada de soja, observaram que o pH neutro da sobremesa é favorável à sobrevivência de probióticos, uma vez que alguns microrganismos probióticos são suscetíveis à inativação quando armazenados sob condições ácidas. É possível que a contínua diminuição do $\mathrm{pH}$ durante o armazenamento do manjar branco T3 e T4, no presente estudo (Figura 9), seja atribuída à presença de L. paracasei.

A redução do $\mathrm{pH}$ ocorrida é um processo natural decorrente da produção contínua de ácido lático e outros ácidos orgânicos pela cultura probiótica de L. paracasei. Como observado por Kourkoutas et al. (2005), células de L. casei imobilizadas em pedaços de frutas (maçã e marmelo) mostraram, no caso do marmelo suplementado de $L$. casei, um pH final mais baixo após o armazenamento. De acordo com Kos et al. (2000), é melhor introduzir as cepas probióticas em um sistema tampão como o leite, iogurte ou soro de leite. Os autores observaram que o leite, as proteínas do soro e a mucina agem como agentes tampões e inibidores da atividade da protease digestiva in vivo. 


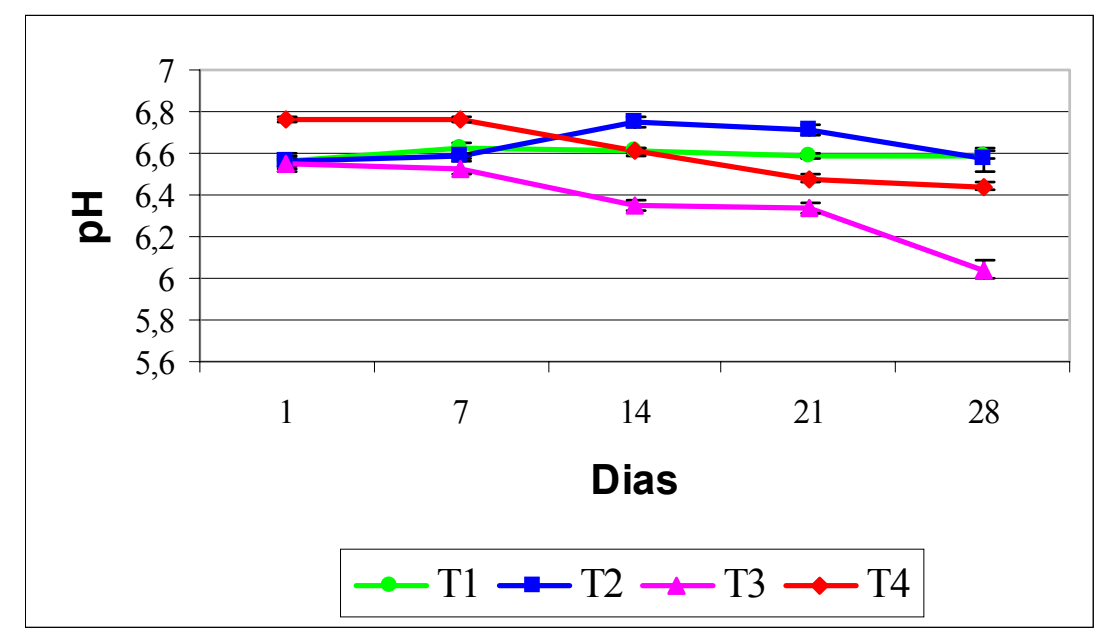

Figura 9 - Valores médios de pH obtidos para os manjares T1, T2, T3 e T4 durante o armazenamento a $4 \pm 1^{\circ} \mathrm{C}$ (ver Tabela 17 para descrição de T1, T2, T3 e T4)

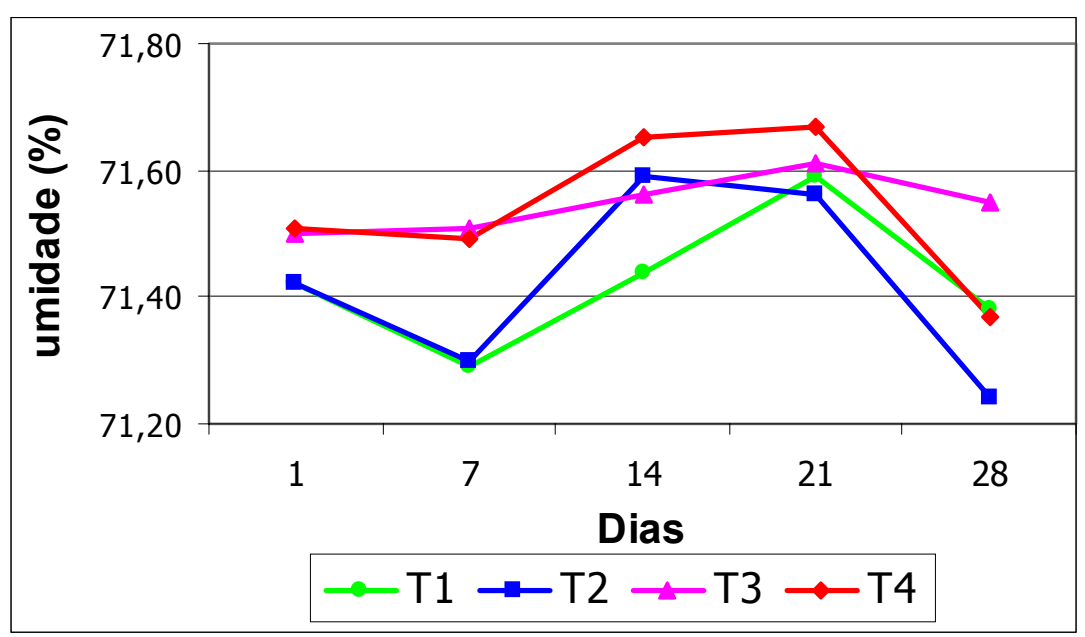

Figura 10 - Valores médios de umidade obtidos para os manjares brancos T1, T2, T3 e T4 durante o armazenamento a $4 \pm 1^{\circ} \mathrm{C}$ (ver Tabela 17 para descrição de T1, T2, T3 e T4) 
Tabela 24 - Valores médios* de pH e umidade obtidos para os manjares brancos T1, T2, T3 e T4 durante o armazenamento a $4 \pm 1^{\circ} \mathrm{C}$ (ver Tabela 17 para descrição de T1, T2, T3 e T4)

\begin{tabular}{|c|c|c|c|}
\hline Tratamentos & $\begin{array}{l}\text { Armazenamento } \\
\text { (dias) }\end{array}$ & $\mathrm{pH}$ & Umidade (\%) \\
\hline \multirow{5}{*}{$\mathrm{T} 1$} & 1 & $6,56^{\mathrm{Aa}}(0,02)$ & $71,42^{\mathrm{Aa}}(0,26)$ \\
\hline & 7 & $6,62^{\mathrm{Bc}}(0,03)$ & $71,29^{\mathrm{Aa}}(0,56)$ \\
\hline & 14 & $6,61^{\mathrm{Bbc}}(0,01)$ & $71,44^{\mathrm{Aa}}(0,29)$ \\
\hline & 21 & $6,59^{\mathrm{Cb}}(0,01)$ & $71,59^{\mathrm{Aa}}(0,10)$ \\
\hline & 28 & $6,59^{\mathrm{Cb}}(0,02)$ & $71,38^{\mathrm{Aa}}(0,53)$ \\
\hline \multirow{5}{*}{$\mathrm{T} 2$} & 1 & $6,56^{\mathrm{Aa}}(0,04)$ & $71,42^{\mathrm{Aa}}(0,40)$ \\
\hline & 7 & $6,59^{\mathrm{Ca}}(0,01)$ & $71,30^{\mathrm{Aa}}(0,74)$ \\
\hline & 14 & $6,75^{\mathrm{Cb}}(0,02)$ & $71,59^{\mathrm{Aa}}(0,22)$ \\
\hline & 21 & $6,71^{\mathrm{Dc}}(0,02)$ & $71,56^{\mathrm{Aa}}(0,10)$ \\
\hline & 28 & $6,57^{\mathrm{Ca}}(0,06)$ & $71,24^{\mathrm{Aa}}(0,66)$ \\
\hline \multirow{5}{*}{$\mathrm{T} 3$} & 1 & $6,55^{\mathrm{Aa}}(0,04)$ & $71,50^{\mathrm{Aa}}(0,10)$ \\
\hline & 7 & $6,53^{\mathrm{Aa}}(0,03)$ & $71,51^{\mathrm{Aa}}(0,16)$ \\
\hline & 14 & $6,35^{\mathrm{Ab}}(0,03)$ & $71,56^{\mathrm{Aa}}(0,14)$ \\
\hline & 21 & $6,34^{\mathrm{Ab}}(0,02)$ & $71,61^{\mathrm{Aa}}(0,06)$ \\
\hline & 28 & $6,04^{\mathrm{Ac}}(0,04)$ & $71,55^{\mathrm{Aa}}(0,12)$ \\
\hline \multirow{5}{*}{$\mathrm{T} 4$} & 1 & $6,76^{\mathrm{Bd}}(0,01)$ & $71,51^{\mathrm{Aa}}(0,30)$ \\
\hline & 7 & $6,76^{\mathrm{Dd}}(0,01)$ & $71,49^{\mathrm{Aa}}(0,41)$ \\
\hline & 14 & $6,61^{\mathrm{Bc}}(0,02)$ & $71,65^{\mathrm{Aa}}(0,17)$ \\
\hline & 21 & $6,48^{\mathrm{Bb}}(0,02)$ & $71,67^{\mathrm{Aa}}(0,07)$ \\
\hline & 28 & $6,44^{\mathrm{Ba}}(0,02)$ & $71,37^{\mathrm{Aa}}(0,47)$ \\
\hline
\end{tabular}

* valores médios de 3 ensaios (repetições) de cada manjar branco (com desvio-padrão entre parêntesis).

$A, B, C$ sobrescritas maiúsculas distintas na mesma coluna indicam as diferenças significativas $(p<0,05)$ entre os diferentes tratamentos, para um mesmo período de armazenamento.

$a$, b, c sobrescritas minúsculas distintas na mesma coluna indicam as diferenças significativas $(p<0,05)$ entre os diferentes dias de armazenamento, para cada tratamento,.

\subsubsection{Textura instrumental}

Textura pode ser considerada uma manifestação das propriedades reológicas do alimento. É um atributo importante que influencia hábitos alimentares, afeta a preferência do consumidor por alimentos "aceitáveis", afetando o processo e 
manuseio dos alimentos e influenciando a saúde oral (SZCZESNIAK, 1963).

A textura é considerada um dos quatro fatores de qualidade dos produtos alimentícios, sendo os outros três o sabor, a aparência e o valor nutricional (MESSENS et al., 2000). O aspecto visual promove a expectativa do sabor e textura do alimento. Sabor é estritamente definido como resposta da língua a materiais solúveis e não voláteis. As propriedades de textura dos alimentos têm efeito substancial na percepção do sabor, sendo dada atenção particular ao efeito da viscosidade. A importância da interação entre a textura dos alimentos e seu sabor percebido pode ser claramente visto no tempo de curso dos eventos, no qual o tempo de consumo do alimento é considerado. Muitos estudos, nos quais a importância de diferentes modalidades sensoriais para a aceitabilidade do consumidor é investigada, levam à conclusão de que o sabor é a modalidade mais importante, seguida pela textura e aparência. Tais conclusões não refletem o enorme esforço que as indústrias de alimentos empregam para desenvolver características de textura favoráveis e mantê-las durante a vida de prateleira (ROSENTHAL, 1999).

Szczesniak e Kleyn (1963) compilaram estudos realizados mundialmente e mostraram que o conhecimento da textura depende de fatores como sexo (mulheres são mais conscientes sobre textura do que os homens), experiências (pessoas trabalhando com alimentos são mais conscientes sobre a textura), classe socioeconômica (consumidores em altos grupos socioeconômicos são mais conscientes do que aquelas de baixos grupos) e tipo de alimento. Szczesniak (1983) também investigou a possibilidade de haver preferências "natas" por texturas específicas.

Os testes instrumentais de textura são geralmente baseados em força de compressão, com a função de simular a mastigação entre os molares (FOX et al., 2000). Durante as primeiras "mastigadas" a maior parte da estrutura do alimento é quebrada. Durante esses ciclos de mastigação, vários tipos de características de textura são percebidos, como a natureza das partículas, consistência e adesão ao pálato. A taxa de quebra aplicada na boca depende da viscosidade do alimento, variando de um para outro, assim alimentos com alta viscosidade tendem a ter uma taxa de quebra menor, e vice-versa (ROSENTHAL, 1999). No teste de dupla compressão, utilizado no presente trabalho, a amostra é submetida a duas "mordidas" ou corridas, que simulam o ato de mastigação. Quando o pistão deforma 
a amostra, o movimento do suporte é detectado e uma curva de força - compressão é traçada (Figura 11). A partir dessa curva, obtém-se os parâmetros primários, firmeza, coesividade, adesividade, elasticidade, e secundários, mastigabilidade e gomosidade, que compõem as características mecânicas do produto (FOX et al., 2000). Essa técnica imita o que acontece na boca, porém deve-se tomar cuidado para aceitar os resultados com outros propósitos distintos da avaliação comparativa (ROSENTHAL, 1999).

A textura é detectada através de estímulos de multifatores, nos quais a maioria das medidas instrumentais tende a se concentrar em uma propriedade do alimento. Não é possível assumir que há necessariamente alguma relação entre medidas instrumentais e experiência sensorial (ROSENTHAL, 1999).

A Figura 11 mostra a curva típica de análise do perfil de textura, bem como o modo de obtenção dos parâmetros, através do programa "Texture Expert for Windows" - versão 1.20 (Stable Micro Systems), a partir de amostra do manjar branco T4 do presente trabalho, em texturômetro TA-XT2 (Stable Micro Systems). Curvas semelhantes foram obtidas para as amostras dos manjares T1, T2 e T3.

H

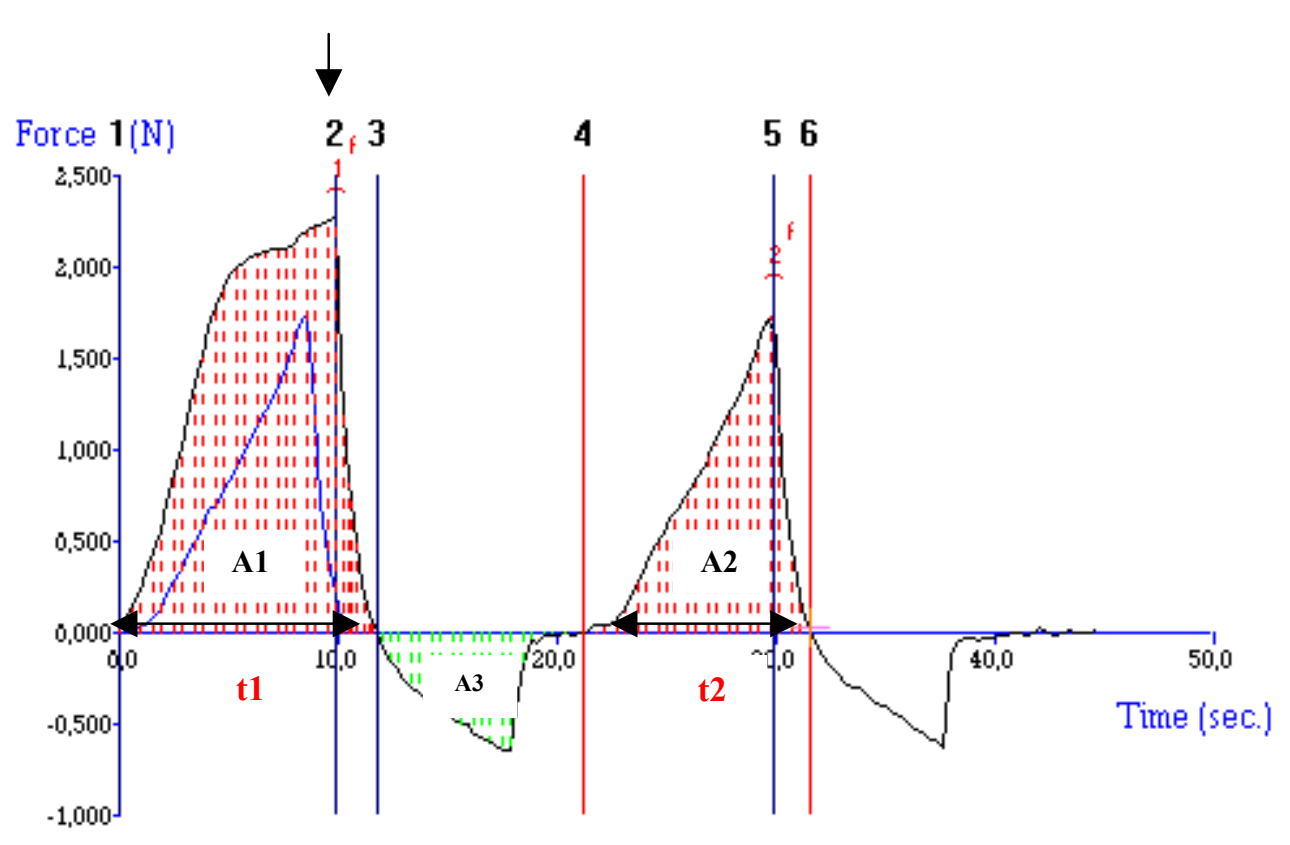

Figura 11: Gráfico da análise do perfil de textura obtido para o manjar T4 (Bifidobacterium longum e L.paracasei), após 14 dias de fabricação. Firmeza = força $(\mathrm{gF})$ atingida em $\mathrm{H}$; Coesividade = razão entre as áreas $\mathrm{A} 2$ e $\mathrm{A} 1$; Adesividade = trabalho em A3; Elasticidade = razão entre t2 e t1; Gomosidade = força $(g F)$ em H x (A2/A1). 
A Tabela 25 mostra as médias obtidas para os parâmetros firmeza, coesividade, adesividade, elasticidade, gomosidade e mastigabilidade dos manjares T1, T2, T3 e T4. Os valores médios de firmeza, adesividade, gomosidade e mastigabilidade dos manjares T1, T2, T3 e T4 ao longo do armazenamento apresentaram grande variação entre os ensaios realizados para cada manjar e, portanto, os desvios-padrão desses parâmetros foram bastante elevados. A adesividade é um parâmetro cujos dados obtidos são negativos. Os valores de adesividade encontrados foram apresentados em módulo.

Tabela 25 - Perfil de textura (média \pm desvio-padrão)* dos manjares brancos T1, T2, T3 e T4 durante o armazenamento a $4 \pm 1^{\circ} \mathrm{C}$ (ver Tabela 17 para a descrição de $\mathrm{T} 1$, T2, T3 e T4).

\begin{tabular}{|c|c|c|c|c|c|c|c|}
\hline $\begin{array}{l}\text { Manjar } \\
\text { branco }\end{array}$ & Dias & Firmeza $(\mathrm{gF})$ & Coesividade & Adesividade $^{2}\left(\mathrm{gs}^{-1}\right)$ & Elasticidade & Gomosidade $(\mathrm{gF})$ & Mastigabilidade \\
\hline \multirow{5}{*}{$\mathrm{T} 1$} & 1 & $183,87^{\mathrm{ABa}}(31,10)$ & $0,51^{\mathrm{Ad}}(0,03)$ & $139,35^{\mathrm{Ac}}(53,85)$ & $0,83^{\mathrm{Ac}}(0,05)$ & $91,52^{\mathrm{ABa}}(12,60)$ & $76,52^{\mathrm{Ba}}(11,89)$ \\
\hline & 7 & $236,89^{\mathrm{Cb}}(59,62)$ & $0,41^{\mathrm{Ac}}(0,03)$ & $137,43^{\mathrm{Ac}}(83,90)$ & $0,76^{\mathrm{Ab}}(0,07)$ & $95,42^{\mathrm{Ab}}(19,10)$ & $73,21^{\mathrm{Aa}}(18,33)$ \\
\hline & 14 & $294,06^{\mathrm{Bc}}(71,64)$ & $0,36^{\mathrm{Ab}}(0,02)$ & $125,70^{\mathrm{Aac}}(79,30)$ & $0,65^{\mathrm{Aa}}(0,10)$ & $106,03^{\mathrm{Abc}}(24,78)$ & $70,01^{\mathrm{Aa}}(23,90)$ \\
\hline & 21 & $319,82^{\mathrm{Bcd}}(61,27)$ & $0,34^{\mathrm{Aa}}(0,02)$ & $80,59^{\mathrm{Aab}}(47,20)$ & $0,59^{\mathrm{Aa}}(0,06)$ & $110,75^{\mathrm{Abc}}(23,82)$ & $66,24^{\mathrm{Aa}}(18,50)$ \\
\hline & 28 & $350,88^{\mathrm{Bd}}(68,66)$ & $0,33^{\mathrm{Aa}}(0,02)$ & $105,52^{\mathrm{Abc}}(49,22)$ & $0,58^{\mathrm{Aa}}(0,07)$ & $117,87^{\mathrm{Ac}}(26,50)$ & $69,57^{\mathrm{Aa}}(19,73)$ \\
\hline \multirow{5}{*}{$\mathrm{T} 2$} & 1 & $176,83^{\mathrm{ABa}}(21,75)$ & $0,52^{\mathrm{Ad}}(0,01)$ & $144,09^{\mathrm{ABa}}(44,68)$ & $0,85^{\mathrm{Aa}}(0,04)$ & $90,99^{\mathrm{Aa}}(9,61)$ & $77,53^{\mathrm{ABa}}(10,39)$ \\
\hline & 7 & $208,30^{\mathrm{BCb}}(25,78)$ & $0,44^{\mathrm{Bc}}(0,01)$ & $161,86^{\mathrm{Aa}}(45,48)$ & $0,88^{\mathrm{Ba}}(0,04)$ & $32,03^{\mathrm{Aa}}(11,91)$ & $80,95^{\mathrm{Aa}}(12,81)$ \\
\hline & 14 & $238,21^{\mathrm{Ac}}(11,18)$ & $0,42^{\mathrm{Bba}}(0,04)$ & $181,68^{\mathrm{Aa}}(100,00)$ & $0,80^{\mathrm{Bab}}(0,08)$ & $98,85^{\mathrm{Aab}}(9,41)$ & $79,91^{\mathrm{Aa}}(14,35)$ \\
\hline & 21 & $270,59^{\mathrm{Ad}}(23,33)$ & $0,39^{\mathrm{Cb}}(0,03)$ & $161,37^{\mathrm{Ba}}(82,81)$ & $0,72^{\mathrm{Bbc}}(0,11)$ & $106,25^{\mathrm{Ab}}(11,48)$ & $77,03^{\mathrm{ABa}}(14,89)$ \\
\hline & 28 & $294,70^{\mathrm{Ae}}(27,28)$ & $0,37^{\mathrm{Ca}}(0,04)$ & $196,60^{\mathrm{Ca}}(140,27)$ & $0,74^{\mathrm{BCbc}}(0,11)$ & $107,64^{\mathrm{Ab}}(13,79)$ & $81,18^{\mathrm{ABa}}(20,39)$ \\
\hline \multirow{5}{*}{$\mathrm{T} 3$} & 1 & $163,79^{\mathrm{Aa}}(18,14)$ & $0,53^{\mathrm{Bd}}(0,01)$ & $173,99^{\mathrm{ABb}}(49,27)$ & $0,86^{\mathrm{Aa}}(0,03)$ & $85,65^{\mathrm{Aa}}(9,81)$ & $73,54^{\mathrm{ABa}}(9,91)$ \\
\hline & 7 & $199,92^{\mathrm{ACb}}(31,91)$ & $0,44^{\mathrm{Bc}}(0,03)$ & $174,98^{\mathrm{Abc}}(47,24)$ & $0,82^{\mathrm{Cb}}(0,08)$ & $87,38^{\mathrm{Aa}}(13,89)$ & $71,89^{\mathrm{Aa}}(12,93)$ \\
\hline & 14 & $273,99^{\mathrm{Ac}}(52,56)$ & $0,37^{\mathrm{Ab}}(0,04)$ & $208,64^{\mathrm{Ac}}(61,80)$ & $0,78^{\mathrm{Bc}}(0,08)$ & $100,35^{\mathrm{Ab}}(13,25)$ & $78,45^{\mathrm{Aa}}(12,32)$ \\
\hline & 21 & $309,01^{\mathrm{Bc}}(48,63)$ & $0,32^{\mathrm{Ba}}(0,02)$ & $153,55^{\mathrm{Ba}}(96,80)$ & $0,70^{\mathrm{Bc}}(0,05)$ & $99,75^{\mathrm{Ab}}(14,48)$ & $69,52^{\mathrm{Aa}}(15,42)$ \\
\hline & 28 & $354,17^{\mathrm{Bd}}(41,59)$ & $0,32^{\mathrm{Ba}}(0,03)$ & $170,98^{\mathrm{Ba}}(87,99)$ & $0,67^{\mathrm{Bd}}(0,07)$ & $112,27^{\mathrm{Ac}}(15,64)$ & $75,74^{\mathrm{Aa}}(13,13)$ \\
\hline \multirow{5}{*}{$\mathrm{T} 4$} & 1 & $191,65^{\mathrm{Ba}}(17,65)$ & $0,51^{\mathrm{ABe}}(0,04)$ & $175,69^{\mathrm{Ba}}(36,73)$ & $0,89^{\mathrm{Bc}}(0,03)$ & $97,82^{\mathrm{Bab}}(5,41)$ & $87,15^{\mathrm{Ca}}(10,74)$ \\
\hline & 7 & $218,24^{\mathrm{Ab}}(14,02)$ & $0,44^{\mathrm{Bd}}(0,03)$ & $159,25^{\mathrm{Aa}}(50,29)$ & $0,83^{\mathrm{Cb}}(0,06)$ & $95,04^{\mathrm{Aa}}(7,74)$ & $79,46^{\mathrm{Aa}}(11,46)$ \\
\hline & 14 & $271,09^{\mathrm{Ac}}(15,14)$ & $0,38^{\mathrm{Ac}}(0,03)$ & $177,53^{\mathrm{Aa}}(58,04)$ & $0,81^{\mathrm{Bb}}(0,07)$ & $102,25^{\mathrm{Ab}}(8,69)$ & $83,34^{\mathrm{Aa}}(11,05)$ \\
\hline & 21 & $314,99^{\mathrm{Bd}}(22,49)$ & $0,35^{\mathrm{Ab}}(0,03)$ & $157,88^{\mathrm{Ba}}(89,31)$ & $0,74^{\mathrm{Ba}}(0,09)$ & $111,73^{\mathrm{Ac}}(13,14)$ & $83,06^{\mathrm{Ba}}(12,75)$ \\
\hline & 28 & $347,51^{\mathrm{Be}}(26,67)$ & $0,33^{\mathrm{ABa}}(0,02)$ & $184,31^{\mathrm{BCa}}(49,19)$ & $0,75^{\mathrm{Ca}}(0,06)$ & $116,01^{\mathrm{Ac}}(12,77)$ & $87,15^{\mathrm{Ba}}(10,74)$ \\
\hline
\end{tabular}


De maneira geral, os manjares T1, T2, T3 e T4 diferiram significativamente entre si, quanto à firmeza, coesividade, adesividade, mastigabilidade e elasticidade $(p<0,05)$, exceto para a gomosidade $(p>0,05)$.

A dureza, ou firmeza, é a força necessária para realizar uma determinada deformação, ponto de deformação ou penetração (SZCZESNIAK, 1998; FOX et al., 2000), podendo ser entendida também como a força requerida para comprimir o manjar entre os dentes molares ou entre a língua e o palato.

Os manjares T1, T2, T3 e T4 apresentaram aumentos significativos $(p<0,05)$ da firmeza durante todo o período de armazenamento (Tabela 25). A retrogradação do amido pode ter aumentado a firmeza do manjar com o tempo. Muitos resultados encontrados podem ser oriundos das diferenças potenciais entre as amostras, como resultados da dessora. Foi verificada diferença significativa $(p<0,05)$ (Tabela 25) para o manjar T4 ao $1^{\circ}$ e ao $7^{\circ}$ dias. O manjar T2 diferiu significativamente $(p<0,05)$ ao $28^{\circ}$ dia de T1, T3 e T4. O açúcar e a gordura presentes nas matérias primas fornecem alta firmeza ao manjar e sem esses ingredientes a qualidade do manjar branco não seria a desejada.

A coesividade é a resistência das ligações internas, ou seja, a quantidade de deformação que o alimento sofre antes de sua ruptura quando comprimido (SZCZESNIAK, 1998; FOX et al., 2000). Os valores de coesividade diminuíram significativamente $(p<0,05)$ (Tabela 25) ao longo do armazenamento para todos os tratamentos. O decréscimo pode ter sido causado pela perda da atração intermolecular entre os ingredientes, levando à dessora. T2 apresentou valores de coesividade significativamente mais elevados que T1, T3 e T4 $(p<0,05)$ ao $28^{\circ}$ dia. Esse fato pode ser atribuído à cristalização do amido, à hidrólise da gordura e à migração da água que podem, durante o armazenamento, levar a um gradual desarranjo da estrutura de um produto contendo amido (ESTELLER et al., 2004), como é o caso do manjar. A adição do açúcar ao manjar branco, possibilita que o manjar sofra menos deformações e mantenha-se mais estável durante sua vida de prateleira, devido ao aumento do valor da coesividade.

A adesividade é definida como o trabalho necessário para superar as forças atrativas entre a superfície do alimento e outras superfícies em que o alimento entra em contato, ou ainda, a força requerida para remover o alimento que aderiu ao céu da boca, geralmente o palato, mas também lábios e dentes durante a mastigação (SZCZESNIAK, 1998; FOX et al., 2000). Esse parâmetro mostrou grande variação 
nos valores. A adesividade em módulo dos manjares T2 e T4 não diferiu significativamente $(p>0,05)$ (Tabela 25$)$ durante o período de armazenamento. Já T1 e T3 tiveram uma variação significativa $(p<0,05)$ ao $21^{\circ}$ e $28^{\circ}$ dias de armazenamento. No final da vida de prateleira $\left(21\right.$ e $28^{\circ}$ dia) verifica-se um valor de adesividade menor para T1 e T3, o que pode indicar uma maior quebra da estrutura desses produtos durante o armazenamento, resultando em uma maior dessora. Isso pode, também, ser devido à produção de ácido por L. paracasei, já que o pH para T1 e T3 é menor do que para T2 e T4. T1 diferiu significativamente $(p<0,05)$ de T2, T3 e $\mathrm{T} 4$ apenas ao $21^{\circ}$ e $28^{\circ}$ dias de armazenamento.

A elasticidade é a razão na qual um material deformado volta à sua condição não deformada, após remoção da força de deformação, o grau e a velocidade com que o material retorna a sua altura original, seguido de parcial compressão com os dentes molares (FOX et al., 2000). Houve diminuição significativa $(p<0,05)($ Tabela 25) da elasticidade nos manjares desenvolvidos no presente trabalho. T1 e T3 sofreram uma diminuição significativa $(\mathrm{p}<0,05)$ ao $7^{\circ}$ e ao $14^{\circ}$ dias, mantendo-se estáveis, em seguida, até o final do armazenamento para T1 e até o $21^{\circ}$ dia para T3. T2 e T4 tiveram diminuição significativa da elasticidade $(p<0,05)$ ao $21^{\circ}$ dia, mantendo-se estáveis em seguida, até o final do armazenamento. O controle T1 diferiu significativamente $(p<0,05)$ de T2, T3 e T4, adicionados de microrganismos, a partir do $7^{\circ}$ dia. O manjar branco com pouca elasticidade tende a quebrar quando desenformado. Todos os valores encontrados para o manjar branco ao final da vida de prateleira refletem em um produto com excelente elasticidade, quando comparado a outros produtos, como musses e pães, sendo que esse último apresenta elasticidade igual a 0,90 g.s ${ }^{-1}$ (ESTELLER et al., 2004).

A gomosidade é a energia requerida para desintegrar um alimento semi-sólido a um estado pronto para ser deglutido, sendo produto da firmeza pela coesividade (SZCZESNIAK, 1998; FOX et al., 2000). Os manjares T1, T2, T3 e T4 não diferiram significativamente entre si quanto à gomosidade durante os 28 dias de armazenamento. Os valores de gomosidade tiveram um aumento significativo para os manjares a partir do $14^{\circ}$ dia de armazenamento $(p<0,05)$. A gomosidade apresenta uma relação positiva e forte com a adesividade. O seu aumento também pode ser explicado como sendo conseqüente do aumento da dessora durante o armazenamento.

A mastigabilidade é a energia requerida para mastigar um alimento sólido até que 
ele esteja pronto para ser deglutido. É um dos parâmetros mais facilmente correlacionados com as análises sensoriais com provadores treinados (ROSENTHAL, 1999). Os manjares T1, T2, T3 e T4 não diferiram significativamente $(p>0,05)$ entre si quanto a mastigabilidade durante os 28 dias. A mastigabilidade também não diferiu significativamente durante todo o período de armazenamento para cada manjar, com exceção do manjar T4, que diferiu significativamente de T1 e de T3 ao $21^{\circ}$ e $28^{\circ}$ dias de armazenamento $(p<0,05)$. O aumento da firmeza promove mais trabalho mecânico e, conseqüentemente, movimento da boca, provocando também um aumento na mastigabilidade.

É possível que, no presente trabalho, os parâmetros firmeza, adesividade, gomosidade e mastigabilidade dos manjares T1, T2, T3 e T4 foram, em parte, influenciados pelo teor de gordura presente, resultado do emprego do leite de coco, coco e leite, que mostram certa variação quanto à composição nos ensaios realizados. Por outro lado, tais diferenças não interferiram nos valores de coesividade e elasticidade, que apresentaram baixa variação entre os 4 ensaios de cada manjar branco (Tabela 25). Cabe aqui enfatizar que os dados instrumentais de coesividade e elasticidade, que apresentaram os menores valores de desvio-padrão, não poderiam ter sido obtidos através do teste de simples compressão, justificando, dessa forma, o emprego do teste de dupla compressão no presente trabalho.

Alguns ingredientes alteram o tipo de textura do alimento, como é o caso da goma carragena e do amido de milho. A goma carragena é freqüentemente empregada em combinação com amido em sobremesas lácteas geleificadas. $O$ amido acrescenta corpo e sabor ao produto, enquanto a goma carragena, empregada na elaboração de manjar branco no presente trabalho, promove uma textura adequada, firme e brilhante. Esta é freqüentemente utilizada como agente geleificante em sobremesas lácteas, devido a sua reatividade com o leite, que se dá através da interação eletrostática entre a carga positiva da K-caseína e os grupos negativos de sulfato da goma carragena. Uma mudança também na quantidade de água ou açúcar no produto pode afetar a quantidade de água disponível e assim ter seu próprio efeito nas propriedades de textura da sobremesa (VERBEKEN et al., 2004).

WIJK et al. (2003) em estudo com pudim de baunilha relataram que a textura é afetada pela quantidade de amido e de goma carragena. Aumentando-se a quantidade de amido ou adicionando goma carragena pode-se observar um grande 
aumento nos atributos como o "engrossamento" e "compactividade" do pudim, e uma correspondente diminuição no atributo "maciez". Adicionando-se gordura temos o mesmo efeito quando adicionado amido e goma carragena ao pudim, porém o efeito é relativamente pequeno.

ADHIKARI et al. (2003) estudaram o perfil de textura de queijos com pouca gordura, muita gordura e defumados e observaram que todos apresentaram diferenças significativas nos diversos parâmetros avaliados $(p<0,05)$. A firmeza foi correlacionada negativamente com a gomosidade. Queijos com pouca gordura e com muita gordura não se distinguiram durante as análises, apresentando os mesmos valores instrumentais de textura.

\subsubsection{Análise sensorial}

Os valores de aceitabilidade obtidos através da análise sensorial de manjar branco apresentam-se na Figura 12. A ficha do teste de aceitabilidade, com escala hedônica estruturada de 9 pontos encontra-se nos Anexos 2 e 3. Não foi observada nenhuma diferença significativa entre os tratamentos $(p=0,058)$ e durante o período de vida-de-prateleira de 21 dias ( $p=0,243)$. Entretanto, foi observada uma tendência de melhores notas para os manjares adicionados de microrganismos probióticos, comparados ao manjar branco controle. Embora não possa ser considerado significativamente melhor sob o ponto de vista sensorial, o manjar branco T2 mostra uma tendência de um melhor desempenho sensorial, quando comparado a T1. O efeito de interação da combinação de $L$. paracasei e B. longum na aceitabilidade dos manjares ao final da vida-de-prateleira (Figura 13) também não foi significante ( $p=$ 0,082), mas houve uma tendência de redução das notas, quando ambos os microrganismos foram adicionados à formulação de manjar branco.

Durante a avaliação sensorial do manjar branco, no presente trabalho, a maioria dos provadores comentou sobre a falta de açúcar no manjar. De fato, a calda de ameixas não foi adicionada à sobremesa, como usualmente, no propósito de evitar que a calda de ameixas escondesse as características sensoriais do manjar propriamente dito. Além do mais, nenhuma diferença evidente resultante da adição de culturas isoladas ou em co-cultura de bifidobacteria e L. paracasei foi observada nas características sensoriais de manjar branco. 
Os resultados deste estudo para o manjar branco estão em acordo com os observados por Corbo et al. (2001) para o queijo italiano Canestrato Pugliese, também adicionado de bifidobacterias. Os autores relataram que na avaliação sensorial do queijo, após 56 dias de maturação para obtenção de aparência, cor, características mecânicas, odor, sabor e textura, os provadores indicaram que todos os queijos podiam ser caracterizados como o tradicional queijo Canestrato Pugliese, sem diferenças evidentes pela adição de bifidobacterias como culturas isoladas ou em co-cultura nas características sensoriais.

No presente trabalho, o manjar branco não mostrou diferenças evidentes da adição de culturas isoladas ou em co-cultura de bifidobacteria e $L$. paracasei nas características sensoriais. Boylston et al. (2004), em estudo com queijo tipo cheddar, observaram que a adição de bifidobacteria não afetou o sabor, a textura ou a aparência do queijo. A presença de bifidobacteria em queijos resulta em altas concentrações de ácido acético e lático, porém as menores diferenças nos atributos sensoriais de queijos indicam que bifidobacteria não exibe atividade metabólica extensiva (Vinderola et al.,2000b).

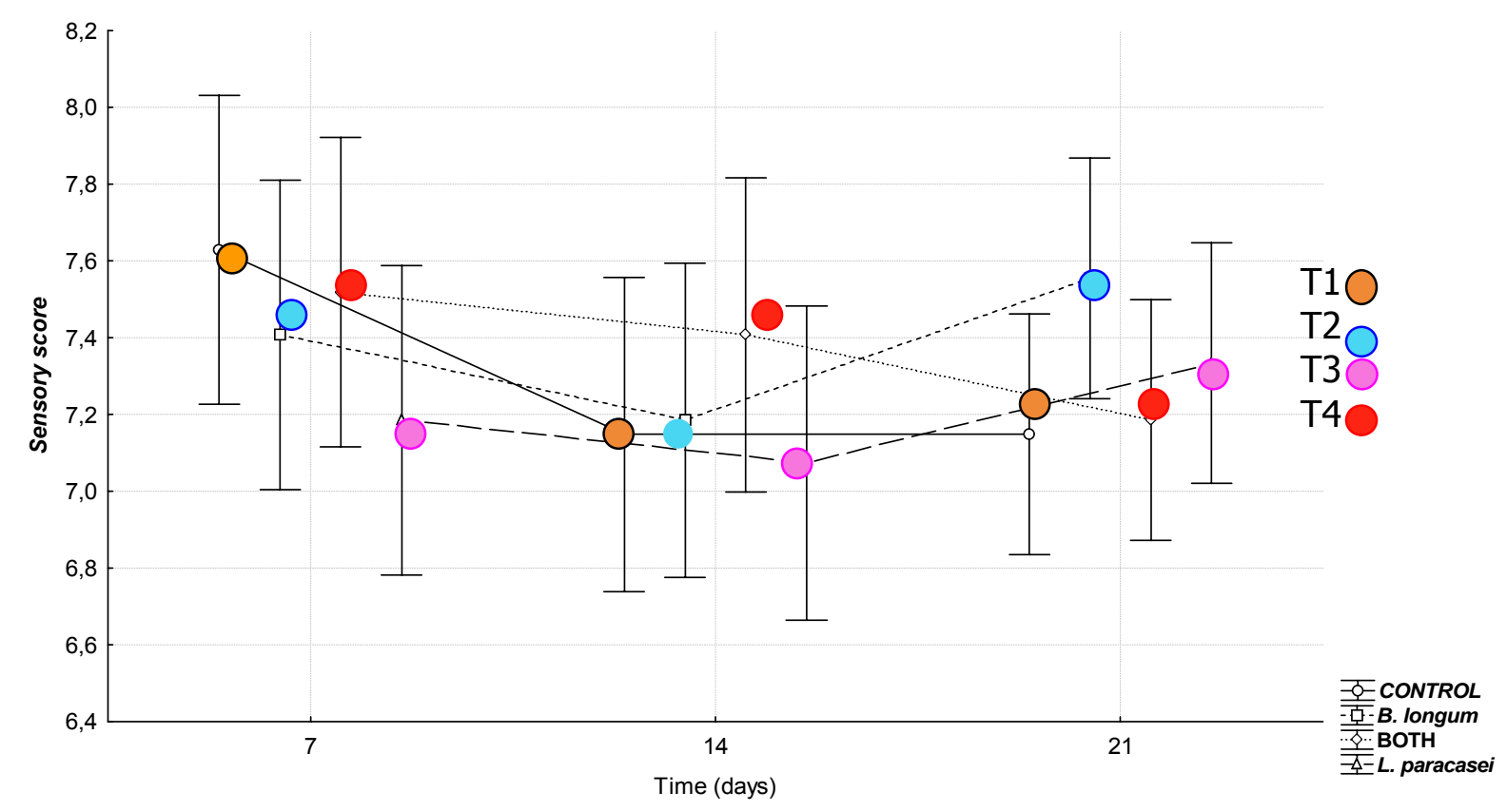

Figura 12 - Notas de aceitabilidade do manjar branco, medidas através de análises sensoriais durante o período de vida-de-prateleira (7, 14 e 21 dias). Os valores são expressos pela média e barras verticais com intervalos de confiança de 0,95 


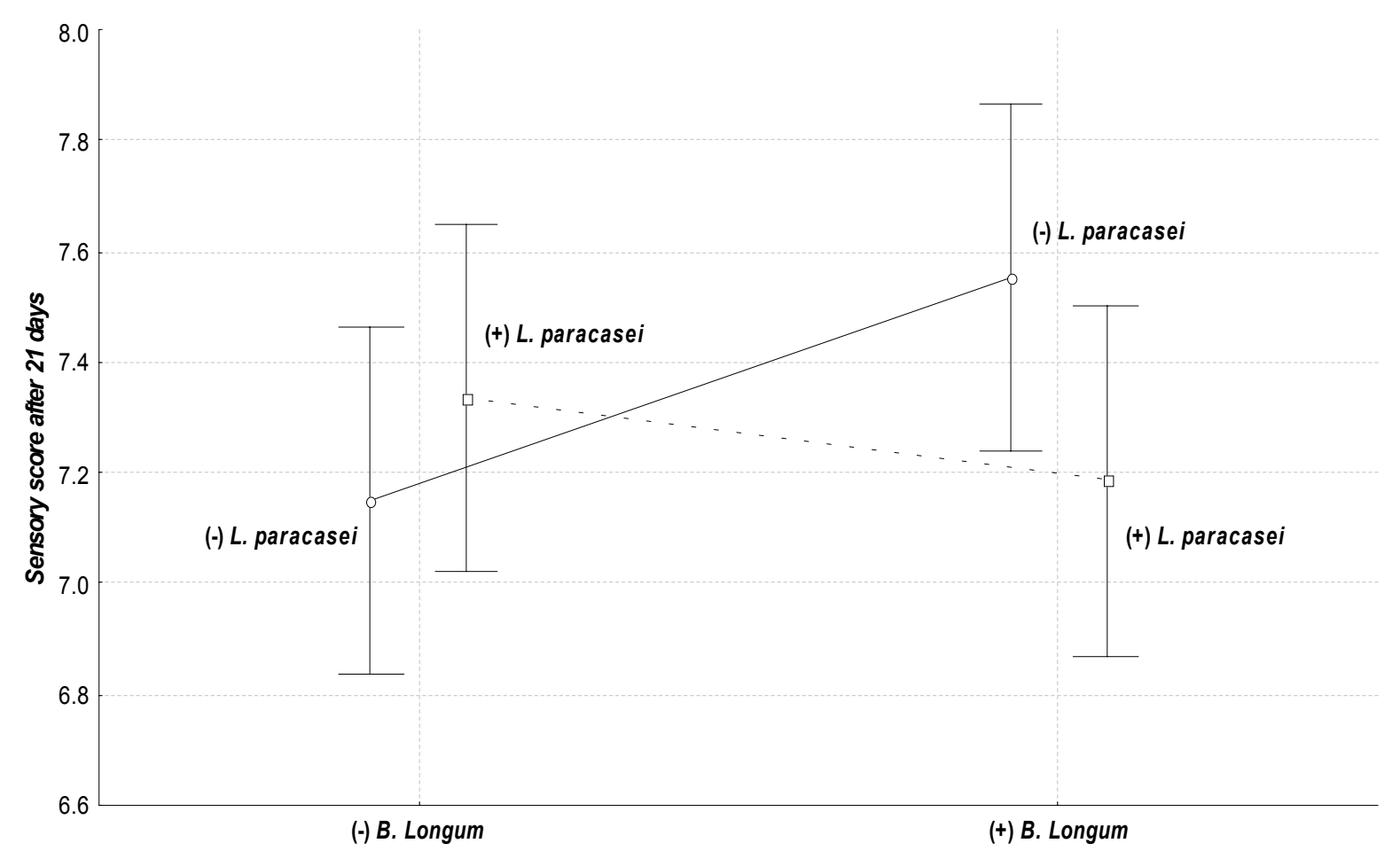

Figura 13 - Interação entre $B$. longum e $L$. paracasei na aceitabilidade de manjar branco, medida pelas análises sensoriais após 21 dias. Os valores são expressos pela média e barras verticais com intervalo de confiança de 0,95

Davidson et al. (2000) observaram que iogurte fermentado e congelado (frozen yoghurt), suplementado com bactérias probióticas, B. longum e L. acidophilus, apresentou pouco efeito no sabor ou na composição centesimal do iogurte gelado. Além disso, o armazenamento refrigerado do produto teve pequeno ou nenhum efeito na sobrevivência das culturas. Estas, por sua vez, permaneceram com níveis suficientes para oferecer os efeitos terapêuticos sugeridos. Por outro lado, iogurte grego produzido com $L$. paracasei subsp. tolerans apresentou excelentes atributos sensoriais, com um sabor tradicional e rico, sendo que o iogurte produzido com a adição desta cepa obteve ótimos parâmetros físico-químicos, alcançando populações maiores ou iguais a 7 log UFC/g (MARAGKOUDAKIS et al., 2006). Kailasapathy (2005) relatou que iogurtes que incorporam culturas probióticas livres e e/ou encapsuladas não sofrem alteração substancial em suas características sensoriais.

Mudanças nos atributos sensoriais durante a vida-de-prateleira de manjar branco não foram previamente relatadas. Os resultados do presente trabalho indicam que 
todos os produtos obtiveram um desempenho sensorial aceitável pelo painel sensorial.

\section{CONCLUSÔES}

- As populações dos microrganismos potencialmente probióticos, obtidas para os manjares brancos estudados, estiveram sempre bastante acima do nível recomendado de $10^{6}$ a $10^{7} \mathrm{UFC} / \mathrm{g}$, satisfazendo, assim, o critério estabelecido para alimentos probióticos

- O manjar branco não mostrou diferenças evidentes da adição de culturas isoladas ou em co-cultura de bifidobacteria e L. paracasei nas características sensoriais. Os resultados indicam que todos os produtos obtiveram um desempenho sensorial aceitável pelo painel sensorial.

- A adição de Lactobacillus paracasei e Bifidobacterium longum ao manjar branco resultou em um produto potencialmente probiótico e com excelentes atributos sensoriais, particularmente quando a adição das culturas foi realizada individualmente (T3 e T2). 


\section{REFERÊNCIAS BIBLIOGRÁFICAS}

ADHIKARI, K.; HEYMANN, H.; HUFF, H.E. Textural characteristics of lowfat, fullfat and smoked cheeses: sensory and instrumental approaches. Food Quality and Preference, v.14, p.211-218, 2003.

AGÊNCIA NACIONAL DE VIGILÂNCIA SANITÁRIA. Gerência de produtos especiais. 2006c [Comunicação].

ALEGRO, J.H.A. Desenvolvimento de queijo Minas frescal probiótico com Lactobacillus acidophilus e Bifidobacterium lactis isolados e em cocultura. São Paulo, 2003. 84p. Dissertação de Mestrado - Faculdade de Ciências Farmacêuticas - Universidade de São Paulo.

ALEGRO, L. C. A.; ALEGRO, J. H. A.; CARDARELLI, H. R.; CHIU, M. C.; SAAD, S. M. I. Potentially Probiotic and Symbiotic Chocolate Mousse. LebensmittelWissenschaft und Technologie, 2006 [no prelo].

ARICI, M.; BILGIN, B.O.; OZDEMIR, C. Some characteristics of Lactobacillus isolates from infant faeces. Food Microbiology, v.21, p.19-24, 2004.

ARUNACHALAM, K. Role of bifidobacteria in nutrition, medicine and technology. Nutrition Research, v.19, n.10, p.1559-1597, 1999.

ASSOCIATION OF OFFICIAL ANALYTICAL CHEMISTS. Official methods of analysis of AOAC international. 17.ed. Gaithersburg: AOAC, 2000. v.1, p.12.1-12.3, v.2, p.33.1-33.88.

BARROS NETO, B.; SCARMINIO, I.S.; BRUNS, R.E. Como fazer experimentos: pesquisa e desenvolvimento na ciência e na indústria. Campinas: UNICAMP, 2003. 401p. (Coleção livro-texto).

BEIGUELMAN, B. Curso prático de bioestatística. 4.ed. Ribeirão Preto: Sociedade Brasileira de Genética, 1996. 242p.

BIELECKA, M.; BIEDRZYCKA, E.; MAJKOWSKA, A. Selection of probiotics and prebiotics for synbiotics and confirmation of their in vivo effectiveness. Food Research International, v.35, n.2/3, p.125-131, 2002.

De acordo com a NBR6023/2000, preconizada pela Associação Brasileira de Normas Técnicas (ABNT). As abreviaturas dos títulos dos periódicos seguem o Chemical Abstracts Service Source Index (CASSI), 2004. 
BLANCHETTE, L.; ROY, D.; BELANGER, G.; GAUTHIER, S.F. Production of cottage cheese using dressing fermented by bifidobacteria. Journal of Dairy Science, v.79, p.8-15, 1996.

BOYLSTON, T.D.; VINDEROLA, C.G.; GHODDUSI, H.B.; REINHEIMER, J.A. Incorporation of bifidobacteria into cheeses: challenges and rewards. International Dairy Journal, v.14, n.5, p.375-387, 2004. [Review].

BRASIL. Ministério da Saúde. Agência Nacional de Vigilância Sanitária. Legislação. VisaLegis. Resolução RDC n.12, de 2 de janeiro de 2001. Aprova o Regulamento Técnico sobre padrões microbiológicos para alimentos. Disponível em: http://elegis.anvisa.gov.br/leisref/public/showAct.php?id=144\&word=. Acesso em: 05 dez. 2005.

BRASIL. Ministério da Saúde. Agência Nacional de Vigilância Sanitária. Legislação. VisaLegis. Portaria SVS/MS n.326, de 30 de julho de 1997. Regulamento técnico sobre as condições higiênico-sanitárias e de boas práticas de fabricação para estabelecimentos produtores/industrializadores de alimentos. Disponível em: http://elegis.anvisa.gov.br/leisref/public/showAct.php?id=100\&word=. Acesso em: 05 dez. 2005.

BRASIL. Portaria no 15, de 30 de abril de 1999. O Ministério da Saúde institui junto à Câmara Técnica de Alimentos a Comissão de Assessoramento de Alimentos Funcionais e Novos Alimentos. Diário Oficial, Brasília, 14 maio 1999. Seção 2.

BURITI, F.C.A. Desenvolvimento de queijo fresco cremoso simbiótico. São Paulo, 2005. 75p. Dissertação de Mestrado - Faculdade de Ciências Farmacêuticas - Universidade de São Paulo.

BURITI, F.C.A.; ROCHA, J.S.; ASSIS, E.G.; SAAD, S.M.I. Probiotic potential of Minas fresh cheese prepared with the addition of Lactobacillus paracasei. LWT-Food Scienc and Technology, v.38, n.2, p.173-180, $2005 a$.

BURITI, F.C.A.; ROCHA, J.S.; SAAD, S.M.I. Incorporation of Lactobacillus acidophilus in Minas fresh cheese and its implications for textural and 
sensorial properties during storage. International Dairy Journal, v.15, n.12, p.1279-1288, 2005b.

CALDER, P.C.; KEW, S. The immune system: a target for functional foods? British Journal of Nutrition, v.88, suppl.1, p.S165-S176, 2002.

CALLEGARI-JACQUES, S.M. Bioestatística: princípios e aplicações. São Paulo: Artmed, 2003. 255p.

CASTRO, I.A.; TIRAPEGUI, J.; SILVA, R.S.S.F.; CUTRIM, A.J.S. Sensory evaluation of a milk formulation supplemented with $\mathrm{n} 3$ polyunsaturated fatty acids and soluble fibres. Food Chemistry, v.85, p.503-512, 2004.

CHARALAMPOPOULOS, D.; WANG, R.; PANDIELLA, S.S.; WEBB, C. Application of cereal and cereal components in functional foods: a review. International Journal of Food Microbiology, v.79, p.131-141, 2002.

CHARTERIS, W.P.; KELLY, P.M.; MORELLI, L.; COLLINS, J.K. Ingredient selection criteria for probiotic microorganisms in functional dairy foods. International Journal of Dairy Technology, v.51, n.4, p.123-136, 1998.

COLLINS, J.K.; THORNTON, G.; SULLIVAN, G.O. Selection of probiotics strains for humans applications. International Dairy Journal, v.8, p.487-490, 1998.

COOK BRASIL. Manjar branco. Disponível em: www.cookbrazil.com/manjar.htm. Acesso em: 10 nov. 2003.

CORBO, M.R.; ALBENZIO, M.; DE ANGELIS, M.; SEVI, A.; GOBBETTI, M. Microbiological and biochemical properties of Canestrato Pugliese hard cheese supplemented with bifidobacteria. Journal of Dairy Science, v.84, p.551-561, 2001.

COSTA NETO, P.L.O. Estatística. São Paulo: Edgard Blücher, 1998. 264p.

DAIGLE, A.; ROY, D.; BÉLANGER, G.; VUILLEMARD, J.C. Production of probiotic cheese (Cheddar-like cheese) using enriched cream fermented by Bifidobacterium infantis. Journal of Dairy Science, v.82, n.6, p.1081-1091, 1999. 
DALY, C.; FITZGERALD, G.F.; O'CONNOR, L.; DAVIS, R. Technological and health benefits of dairy starter cultures. International Dairy Journal, v.8, p.195-205, 1998.

DAVE, R.I.; SHAH, N.P. Effectiveness of ascorbic acid as an oxygen scavenger in improving viability of probiotic bacteria in yogurts made whit commercial starter cultures. International Dairy Journal, v.7, p.435-443, 1997a.

DAVE, R.I.; SHAH, N.P. Ingredient supplementation effects on viability of probiotic bacteria in yogurt. Journal of Dairy Science, v.81, n.11, p.2804-2816, 1998.

DAVE, R.I.; SHAH, N.P. Viability of yogurts and probiotic bacteria in yogurts made from commercial starter cultures. International Dairy Journal, v.7, p.31-41, 1997b.

DAVIDSON, R.H.; DUNCAN, S.E.; HACKNEY, C.R.; EIGEL, W.N.; BOLING, J.W. Probiotic culture survival and implications in fermented frozen yogurt characteristics. Journal of Dairy Science, v.83, n.4, p.666-673, 2000.

DINAKAR, P.; MISTRY, V.V. Growth and viability of Bifidobacterium bifidum in Cheddar cheese. Journal of Dairy Science, v.77, n.10, p.2854-2864, 1994.

ESTELLER, M.S.; AMARAL, R.L., LANNES, S.C.S. Effect of sugar and fat replacers on the texture of baked goods. Journal of Texture Studies, v.35, p.383-393, 2004.

FELIS, G.E.; DELLAGLIO, F.; MIZZI, L.; TORRIANI, S. Comparative sequence analysis of a recA gene fragment brings new evidence for a gange in the taxonomy of the Lactobacillus casei group. International Journal of Systematic and Evolutionary Microbiology, v.51, p.2113-2117, 2001.

FOOD AND AGRICULTURE ORGANIZATION OF THE UNITED NATIONS; WORLD HEALTH ORGANIZATION. Evaluation of health and nutritional properties of probiotics in food including powder milk with live lactic acid bacteria. Córdoba, 2001. 34p. Disponível em: ftp://ftp.fao.org/es/esn/food/probioreport_en.pdf Acesso em: 02 fev. 2005. [Report of a Joint FAO/WHO Expert Consultation].

FOOKS, L.J.; FULLER, R.; GIBSON, G.R. Prebiotics, probiotics and human gut microbiology. International Dairy Journal, v.9, p.53-61, 1999. 
FOX, P.F.; GUINEE, T.P.; COGAN, T.M.; McSWEENEY, P.L.H. Fundamentals of cheese science. Gaithersburg: Aspen, 2000. 587p.

FULLER, R. Probiotics in man and animals. Journal of Applied Bacteriology, v.66, p.365-378, 1989.

GARDINER, G.; ROSS, R.P.; COLLINS, J.K.; FITZGERALD, G.; STANTON, C. Development of a probiotic Cheddar cheese containing human-derived Lactobacillus paracasei strains. Applied and Environmental Microbiology, v.64, p.2192-2199, 1998.

GARDINER, G.; STANTON, C.; LYNCH, P.B.; COLLINS, J.K.; FITZGERALD, G.; ROSS, R.P. Evaluation of cheddar cheese as a food carrier for delivery of a probiotic strain to the gastrintestinal tract. Journal of Dairy Science, v.82, n.7, p.1379-1387, 1999.

GARRO, S.M.; VADEZA, F.G.; GIORIA, S.G. Temperature effect on the biological activity of Bifidobacterium longum CRL 849 and Lactobacillus fermentum CRL 251 in pure and mixed cultures grown in soymilk. International Journal of Food Microbiology, v.21, p.511-518, 2004.

GIBSON, G.R.; FULLER, R. Aspects of in vitro and in vivo research approaches directed toward identifying probiotics and prebiotics for human use. Journal of Nutrition, v.130, p.391S-394S, 2000.

GILLILAND, S.E. Probiotics and prebiotics. In: MARTH, E.H.; STEELE, J.L., eds. Applied dairy microbiology. 2.ed. New York: Marcel Dekker, 2001. p.327343. (Food science and technology, 110).

GILLILAND, S.E.; LARA, R.C. Influence of storage at freezing and subsequent refrigeration temperatures on bgalactosidase activity of Lactobacillus acidophilus. Applied and Environmental Microbiology, v.54, p.898-902, 1988.

GILLILAND, S.E.; SPEAK, M.L. Instability of Lactobacillus acidophilus in yogurt. Journal of Dairy Science, v.60, p.1395-1398, 1977.

GOBBETTI, M.; CORSETTI, A.; SMACCHI, E.; ZOCCHETTI, A.; DE ANGELIS, M. Production of Crescenza cheese by incorporation of bifidobacteria. Journal of Dairy Science, v.81, p.37-47, 1997. 
GOMES, A.M.P.; MALCATA, F.X. Bifidobacterium spp. and Lactobacillus acidophillus: biological, biochemical, technological and therapeutical properties relevant for use as probiotics. Trends in Food Science \& Technology, v.10, p.139-157, 1999.

GOMES, A.M.P.; MALCATA, F.X. Development of probiotic cheese manufactured from goat milk: response surface analysis via technological manipulation. Journal of Dairy Science, v.81, n.6, p.1492-1507, 1998.

GOMES, F.P. Curso de estatística experimental. 12.ed. São Paulo: Nobel, 1987. $467 p$.

GRITTENDEN, G.R. Prebiotics. In: TANNOCK, G.W., ed. Probiotics: a critical review. Norfolk: Horizon Scientific Press, 1999. p.141-156.

GUARNER, F.; MALAGELADA, J.R. Gut flora in health and disease. Lancet, v.360, p.512-518, 2003.

HALSTED, C.H. Dietary supplements and functional foods: 2 sides of a coin? American Journal of Clinical Nutrition, v.77, suppl., p.1001S-1007S, 2003.

HAMMES, W.P.; HERTEL, C. Research approaches for pre-and probiotics: challenges and outlook. Food Research International, Amsterdam, v.35, p.165-170, 2002.

HATTING, A.L.; VILJOEN, B.C. Yogurt as probiotic carrier food. International Dairy Journal, v.11, p.1-17, 2001.

HAVENAAR, R.; BRINK, T.; HUIS IN'T VELDT, J.H.J. In: FULLER, R., ed. Probiotics: the scientific basis. London: Chapmann and Hall, 1992. p.209224.

HEENAN, C.N.; ADAMS, M.C.; HOSKEN, R.W.; FLEET, G.H. Survival and sensory acceptability of probiotic microorganisms in a nonfermented frozen vegetarian dessert. Lebensmittel-Wissenschaft und Technologie, v.37, p.461-466, 2004.

HELLER, K.J.; BOCKELMANN, W.; SCHREZENMEIR, J.; DeVRESE, M. Cheese and its potential as a probiotic food. In: FARNWORTH, E.R., ed. Handbook of fermented functional foods. Boca Raton: CRC Press, 2003. p.203-225. (Functional foods and nutraceuticals series). 
HOIER, E.; JANZEN, T.; HERIKSEN, C.M.; RATTRAY, F.; BROCKMANN, E.; JOHANSEN, E. The production, application and action of lactic cheese starter cultures. In: LAW, B.A., ed. Technology of cheesemaking. Boca Raton: CRC Press, 1999. p.99-131.

HOLZAPFEL, W.H.; HABERER, P.; GEISEN, R.; BJORKROTH, J.; SCHILLINGER, $U$. Taxonomy and important features of probiotic microorganisms in food and nutrition. American Journal of Clinical Nutrition, v.73, p.365S-373S, 2001.

HOLZAPFEL, W.H.; SCHILLINGER, U. Introduction to pre-and probiotics. Food Research International, v.35, n.2/3, p.109-116, 2002.

INSTITUTO ADOLFO LUTZ. Normas analíticas do Instituto Adolfo Lutz: métodos químicos e físicos para análise de alimentos. 3ed. São Paulo: IAL, 1985. $533 p$.

ISOlAURI, E.; SAlMineN, S.; OUWEHAND, A.C. Probiotics. Best Practce \& Research, Clinical Gastroenterology, v.18, n.2, p.299-313, 2004.

ITSARANUWAT, P.; AL-HADDAD, K.S.H.; ROBINSON, R.K. The potential therapeutic benefits of consuming 'health-promoting' fermented dairy products: a brief update. International Journal of Dairy Technology, v.56, n.4, p.203210, 2003.

JELEN, P.; LUTZ, S. Functional milk and dairy products. In: MAZZA, G., ed. Functional foods: biochemical and processing aspects. Lancaster: Technomic Publishing, 1998. p.357-381.

KAILASAPATHY, K. Survival of free and encapsulate probiotic bacteria and their effect on the sensory properties of yoghurt. Lebensmittel-Wissenschaft und Technologie, 2005. [no prelo].

KANDLER, O.; WEISS, N. Genus Lactobacillus: In: SNEATH, P.H.A.; MAIR, N.S.; SHARPE, M.E.; HOLT, J.G., eds. Bergey's manual of systematic bacteriology. 9.ed. Baltimore: Williams and Wilkins, 1986. v.2, p.1063-1065.

KASK, S.; ADAMBERG, K.; ORLOWSKI, A.; VOGENSEN, F.K.; MØLLER, P.L.; ARDÖ, Y.; PAALME, T. Physiological properties of Lactobacillus paracasei, $L$. danicus and $L$. curvatus strains isolated from Estonian semi-hard cheese. Food Research International, v.36, p.1037-1046, 2003. 
KAUR, I.P.; CHOPRA, K.; SAINI, A. Probiotics: potential pharmaceutical applications. European Journal of Pharmaceutical Sciences, v.15, p.1-9, 2002.

KIM, H.S.; GILLILAND, S.E. Lactobacillus acidophilus as a dietary adjunct for milk to aid lactose digestion in humans. Journal of Dairy Science, v.66, n.5, p.959966, 1983.

KLAENHAMMER, T.R. Probiotics and prebiotics. In: DOYLE, M.P.; BEUCHAT, L.R.; MONTVILLE, T.J., eds. Food microbiology: fundamentals and frontiers. 2.ed. Washington: ASM Press, 2001. p.797-811.

KLEIN, G.; PACK, A.; BONAPARTE, C.; REUTER, G. Taxonomi and physiology of probiotic lactic acid bacteria. International Journal of Food Microbiology, v.41, p.103-125, 1998.

KOOP-HOOLIHAN, L. Prophylactic and therapeutic uses of probiotics: a review. Journal of the American Dietetic Association, v.101, p.229-241, 2001.

KORHONEN, H. Technology options for new nutritional concepts. International Journal of Dairy Technology, v.55, n.2, p.79-88, 2002.

KOS, B.; SUSKOVIC, J.; GORETA, J.; MATOSIC, S. Effect of protectors on the viability of Lactobacillus acidophilus M92 in simulated gastrointestinal conditions. Food Technology and Biotechnology, v.38, n.2, p.121-127, 2000.

KOURKOUTAS, Y.; XOLIAS, V.; KALLIS, M.; BEZIRTZOGLOU, E.; KANELLAKI, M. Lactobacillus casei cell immobilization on fruit pieces for probiotic additive, fermented milk and lactic acid production. Process Biochemistry, v.40, p.411-416, 2005.

KRISTO, E.; BILIADERIS, C.G.; TZANETAKIS, N. Modelling of rheological, microbiological and acidification properties of a fermented milk product containing a probiotic strain of Lactobacillus paracasei. International Dairy Journal, v.13, p.517-528, 2003.

LANKAPUTRA, W.E.V.; SHAH, N.P. Survival of Lactobacillus acidophilus and Bifidobacterium spp. in the presence of acid and bile salts. Cultured Dairy Products Journal, v.30, n.3, p.113-118, 1995. 
LAROIA, S.; MARTIN, J.H. Effect of $\mathrm{pH}$ on survival of Bifidobacterium bifidum and Lactobacillus acidophilus in frozen fermented dairy desserts. Cultured Dairy Products Journal, v.2, p.13-21, 1991a.

LEE, Y.K.; NOMOTO, K.; SALMINEN, S.; GORBACH, S.L. Handbook of probiotics. New York, Chichester: Wiley, 1999. 211p.

LEE, Y.K.; SALMINEN, S. The coming age of probiotics. Trends in Food Science \& Technology, v.6, p.241-245, 1995.

LEITES fermentados com probióticos contribuem para uma vida mais saudável. Food Ingredients, v.2, n.6, p.40-46, 2000.

MARAGKOUDAKIS, P.A.; MIARIS, C.; ROJEZ, P.; MANALIS, N.; MAGKANARI, F.; KALANTZOPOULOS, G.; TSAKALIDOU, E. Production of traditional Greek yoghurt using lactobacillus strains with probiotic potential as starter adjuncts. International Dairy Journal, v.16, n.1, p.52-60, 2006.

MATTILA-SANDHOLM, T.; MYLLÄRINEN, P.; CRITTENDEN, R.; MOGENSEN, G.; FONDÉN, R.; SAARELA, M. Technological challenges for future probiotic foods. International Dairy Journal, v.12, p.173-182, 2002.

Mc BREARTY, S.; ROSS, R.P.; FITZGERALD, G.F.; COLLINS, J.K.; WALLACE, J.M.; STANTON, C. Influence of two commercially available bifidobacteria cultures on Cheddar cheese quality. International Dairy Journal, v.11, n.8, p.599-610, 2001.

MEDICI, M.; VINDEROLA, C.G.; PERDIGÓN, G. Gut mucosal immunomodulation by probiotic fresh cheese. International Dairy Journal, v.14, p.611-618, 2004.

MENÉNDEZ, S.; CENTENO, J.A.; GODÍNEZ, R.; RODRÍGUEZ-OTERO, J.L. Effect of Lactobacillus strains on the ripening and organoleptic characteristics of Arzúa-Ulloa cheese. International Journal of Food Microbiology, v.59, p.37-46, 2000.

MESSENS, W.; VAN DE WALLE, D.; AREVALO, J.; DEWETTINCK, K.; HUYGHEBAERT, A. Rheological properties of high-pressure-treated Gouda cheese. International Dairy Journal, v.10, p.359-367, 2000.

MINELLI, E.B.; BENINI, A.; MARZOTTO, M.; SBARBATI, A.; RUZZENENTE, O.; FERRARIO, R.; HENDRIKS, H.; DELLAGLIO, F. Assessment of novel 
probiotic Lactobacillus casei strains for the production of functional dairy foods. International Dairy Journal, v.14, p.723-736, 2004.

MODLER, H.W.; MCKELLAR, R.C.; YAGUCHI, M. Bifiobacteria and bifidogenic factors. Canadian Institute of Food Science and Technology Journal, v.23, p.29-41, 1990.

NAIDU, A.S.; CLEMENS, R.A. Probiotics. In: NAIDU, A.S., ed. Natural food antimicrobial systems. Boca Raton, London: CRC Press, 2000. p.431-462.

NINESS, K.R. Inulin and oligofrutose: what are they? Journal of Nutrition, v.129, suppl.7, p.1402S-1406S, 1999.

NORIEGA, L.; GUEIMONDE, M.; SÁNCHEZ, B.; MARGOLLES, A.; REYES GAVILÁN, C.G. Effect of the adaptation to high bile salts concentrations on glycosidic activity, survival at low $\mathrm{PH}$ and cross-resistance to bile salts in Bifidobacterium. International Journal of Food Microbiology, v.94, n.1, p.79-86, 2004.

OKAZAKI, T.Y.; ALEGRO, J.H.A.; ROCHA, J.S.; SAAD, S.M.I. Microbiological profile of probiotic minas cheese. In: CONGRESSO BRASILEIRO DE MICROBIOLOGIA, 21, Foz do Iguaçu, 2001. Resumos. Rio de Janeiro: Sociedade Brasileira de Microbiologia, 2001. p.389, res.AL-091.

OLIVEIRA, M.N.; SIVIERI, K.; ALEGRO, J.H.A.; SAAD, S.M.I. Aspectos tecnológicos de alimentos funcionais contendo probióticos. Revista Brasileira de Ciências Farmacêuticas, v.38, n.1, p.1-21, 2002.

PEREIRA, D.I.A.; GIBSON, G.R. Effects of consumption of probiotics and prebiotics on serum lipid levels in humans. Critical Reviews in Biochemistry and Molecular Biology, v.37, n.4, p.259-281, 2002.

REHM, H.J.; REED, G.; PUHLER, A.; STADLER, P., eds. Biotechnology: a multivolume comprehensive treatise. 2.ed. Weinheim, New York: VCH, 1993. p.329-333. [Biological fundamentals, v.1].

REID, G.; SANDERS, M.E.; GASKINS, H.R.; GIBSON, G.R.; MERCENIER, A.; RASTALL, R.; ROBERFROID, M.; ROWLAND, I.; CHERBUT, C.; KLAENHAMMER, T.R. New scientific paradigms for probiotics and prebiotics. Journal of Clinical Gastroenterology, v.37,n.2, p.105-118, 2003. 
REILLY, S.S.; GILLILAND, S.E. Bifidobacterium longum survival during frozen and refrigerated storage as related to $\mathrm{pH}$ during growth. Journal of Food Science, v.64, n.4, p.714-718, 1999.

ROBERFROID, M.B. Concepts and strategy of functional food science: the european perspective. American Journal of Clinical Nutrition, v.71, n.6, suppl., p.1660-1664, 2000.

ROBERFROID, M.B. Concepts in functional foods: the case of inulin and oligofructose. Journal of Nutrition, v.129, suppl.7, p.1398S-1401S, 1999a.

ROBINSON, R.K. Therapeutic properties of fermented milks. London, New York: Elsevier Applied Science, 1991. 185p. (Elsevier applied food science series).

ROSENTHAL, A.J. Food Texture. Measurement and Perception. Gaithersburg: Aspen,1999. 311p.

ROY, D.; MAINVILLE, I.; MONDOU, F. Selective enumeration and survival of bifidobacteria in fresh cheese. International Dairy Journal, v.7, p.785-793, 1997.

RYBKA, S.; FLEET, G.H. Populations of Lactobacillus delbrueckii spp. Bulgaricus, Streptococcus thermophilus, Lactobacillus acidophilus and Bifidobacterium species in Australian yogurts. Food Australia, v.49, n.10, p.471-475, 1997.

SAAD, S.M.I. Probióticos e prebióticos: o estado da arte. Revista Brasileira de Ciências Farmacêuticas, v.42, n.1, 2006 [no prelo].

SAARELA, M.; MOGENSEN, G.; FONDEN, R.; MATTO, J.; MATTILA-SANDHOLM, T. Probiotic bacteria: safety, functional and technological properties. Journal of Biotechnology, Amsterdam, v.84, p.197-215, 2000.

SALMINEN, S.; VON WRIGHT, A., eds. Lactic acid bacteria. New York: Marcel Dekker, 1993. 442p.

SAMONA, A.; ROBINSON, R.K. Effect of yogurt culture on the survival of bifidobacteria in fermented milks. Journal of the Society of Dairy Technology, v.42, n.2, p.58-60, 1994.

SANDERS, M.E. Overview of functional foods: emphasis on probiotic bacteria. International Dairy Journal, v.8, p.341-347, 1998. 
SANDERS, M.E. Probiotics: considerations for human health. Nutrition Reviews, v.61, n.3, p.91-99, 2003.

SANDERS, M.E.; KLAENHAMMER, T.R. Invited review: the scientific basis of Lactobacillus acidophilus NCFM functionality as a probiotic. Journal of Dairy Science, v.84, p.319-331, 2001.

SANDINE, W.E.; MURALIDHARA, K.S.; ELLIKER, P.R.; ENGLAND, D.C. Lactic acid bacteria in food and health: a review with special reference to enteropathogenic Escherichia coli as well as certain enteric diseases and their treatment with antibiotics and lactobacilli. Journal of Milk and Food Technology, v.35, n.12, p.691-702, 1972.

SAXELIN, M.; GRENOV, B.; SVENSSON, U.; FONDÉN, R.; RENIERO, R.; MATTILA-SANDHOLM, T. The technology of probiotics. Trends in Food Science \& Technology, v.10, p.387-392, 1999.

SCHIFFRIN, E.J.; BLUM, S. Food processing: probiotic microorganisms for beneficial foods. Current Opinion in Biotechnology, v.12, p.499-502, 2001.

SERVIN, A.L. Antagonistic activities of lactobacilli and bifidobacteria against microbial pathogens. FEMS Microbiology Reviews, v.28, n.4, p.405-440, 2004. [Review].

SHAH, N.P. Probiotic bacteria: selective enumeration and survival in dairy foods. Journal of Dairy Science, v.83, n.4, p.894-907, 2000.

SHAH, N.P.; LANKAPUTHRA, W.E.V. Improving viability of Lactobacillus acidophilus and Bifidobacterium ssp. in yogurt. International Dairy Journal, v.7, p.349356, 1997.

SHIHATA, A.; SHAH, N.P. Proteolytic profiles of yogurt and probiotic bacteria. International Dairy Journal, v.10, p.401-408, 2000.

SHIMAKAWA, Y.; MATSUBARA, S.; YUKI, N.; IKEDA, M.; ISHIKAWA, F. Evaluation of Bifidobacterium breve strain Yakult-fermented soymilk as a probiotic food. International Journal of Food Microbiology, v.81, p.131-136, 2002.

SHORTT, C. The probiotic century: historical and current perspectives. Trends in Food Science \& Technology, v.10, p.411-417, 1999. 
SREEKUMAR, O.; HOSSONO, A. Immediate effect of Lactobacillus acidophilus on the intestinal flora and fecal enzymes of rats and the in vitro inhibition of Escherichia coli in coculture. Journal of Dairy Science, v.83, n.5, p.931-939, 2000.

STANTON, C.; GARDINER, G.; LYNCH, P.B.; COLLINS, J.K.; FITZGERALD, G.; ROSS, R.P. Probiotic cheese. International Dairy Journal, v.8, p.491-496, 1998.

STANTON, C.; ROSS, R.P.; FITZGERALD, G.F.; VAN SINDEREN, D. Fermented functional foods based on probiotics and their biogenic metabolites. Current Opinion in Biotechnology, v.16, n.2, p.198-203, 2005.

STILES, M.E.; HOLZAPFEL, W.H. Lactic acid bacteria of foods and their current taxonomy. International Journal of Food Microbiology, v.36, p.1-29, 1997.

SZCZESNIAK, A.S. Classification of textural characteristics. Journal of Food Science, v.28, p.385-389, 1963.

SZCZESNIAK, A.S. Physical properties of foods: what they are and their relation to other food properties. In: PELEG, M.; BAGLEY, E.B. eds. Physical properties of foods. New York: VanNostrand Reinhold/AVI, 1983. p.1-42.

SZCZESNIAK, A.S. Sensory texture profiling historical and scientific perspectives. Food Technology, v.52, n.8, p.54-57, 1998.

TAMIME, A.Y.; ROBINSON, R.K. Yoghurt: science and technology. Oxford, New York: Pergamon Press, 1985. 431p. (Pergamon International Library of Science, Technology, Engineering and Social Studies).

TEJADA-SIMON, M.V.; LEE, J.H.; USTUNOL, Z.; PESTKA, J.J. Ingestion of yogurt containing L. acidophilus and Bifidobacterium to potentiate immunoglobulin: a responses to cholera toxin in mice. Journal of Dairy Science, v.82, n.4, p.649-680, 1999.

TUOHY, K.M.; PROBERT, H.M.; SMEJKAL, C.W.; GIBSON, G.R. Using probiotics and prebiotics to improve gut health. Drug Discovery Today, v.8, n.15, p.692$700,2003$.

UYSAL, H.; KILIC, S.; KAVAS, G.; AKBULUT, N.; KESENKAS, H. Some properties of set yoghurt made from caprine milk and bovine-caprine milk mixtures 
fortified by ultrafiltration or the addition of skim milk power. International Journal of Dairy Technology, v.56, n.3, p.177-181, 2003.

VAN DE WATER, J. Yogurt and immunity: the health benefits of fermented milk products that contain lactic acid bacteria. In: FARNWORTH, E.R., ed. Handbook of fermented functional foods. Boca Raton: CRC Press, 2003. p.133-144.

VERBEKEN, D.; THAS, O.; DEWETTINCK, K. Textural properties of gelled dairy desserts containing k- carrageenan and starch. Food Hidrocolloids, v.18, p.817-823, 2004.

VINDEROLA, C.G.; BAILO, N.; REINHEIMER, J.A. Survival of probiotic microflora in Argentinian yogurts during refrigerated storage. Food Research International, Amsterdam, v.33, p.97-102, 2000.

VINDEROLA, C.G.; PROSELLO, W.; GHIBERTO, D.; REINHEIMER, J.A. Viability of probiotic (Bifidobacterium, Lactobacillus acidophilus and Lactobacillus casei) and nonprobiotic microflora in Argentinian fresco cheese. Journal of Dairy Science, v.83, n.9, p.1905-1911, 2000b.

VINDEROLA, C.G.; REINHEIMER, J.A. Culture media for the enumeration of Bifidobacterium bifidum and Lactobacillus acidophilus in the presence of yoghurt bactéria. International Dairy Journal, v.9, p.497-505, 1999.

VINDEROLA, C.G.; REINHEIMER, J.A. Lactic acid starter and probiotic bacteria: a comparative "in vitro" study of probiotic characteristics and biological barrier resistance. Food Research International, v.36, p.895-904, 2003.

WIJK, R.A.; VAN GEMERT, L.J.; TERPSTRA, M.E.j.; WILKINSON, C.L. Texture of semi-solids; sensory and instrumental measurements on vanilla custard desserts. Food Quality and Preference, v.14, p.305-317, 2003.

ZIEMER, C.J.; GIBSON, G.R. An overview of probiotics, prebiotics and synbiotics in the functional food concept: perspectives and future strategies. International Dairy Journal, v.8, p.473-479, 1998.

ZUBILLAGA, M.; WEILL, R.; POSTAIRE, E.; GOLDMAN, C.; CARO, R.; BOCCIO, J. Effect of probiotics and functional foods and their use in different diseases. Nutrition Research, v.21, p.569, 2001. 
Anexo 1 - Aprovação da análise sensorial do presente trabalho pelo Comitê de Ética em Pesquisa da Faculdade de Ciências Farmacêuticas - USP 
Ofício CEP no $023 / 2004$

São Paulo, 30 de março de 2004.

IImo(a) Sr(a).

Sabrina Barros de Mattos Corrêa

Vimos informar que o Comitê de Ética em Pesquisa da FCF/USP, em reunião realizada em 29 de março p.P., APROVOU o projeto "Emprego de microorganismos probióticos na produção de manjar branco" (Protocolo n²35) apresentado por Vossa Senhoria, devendo apenas ser apresentado os critérios de inclusão e exclusão dos sujeitos da pesquisa.

Lembramos que após a execução de $50 \%$ do cronograma do projeto. deverá ser apresentado um relatório parcial, de acordo com o Artigo 18 - item C. da Portaria FCF-111/97.

Atenciosamente,

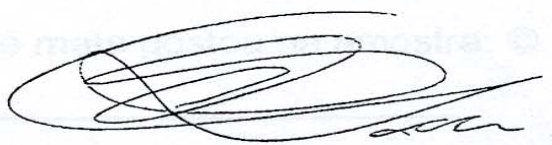

Profa. Dra. Dulcinéia Saes Parra Abdalla

Coordenadora do Comitê de Ética em Pesquisa da FCF/USP

Orientador: Prof. Susana Marta Isay Saad FBT 
Anexo 2 - Modelo da Ficha utilizada na análise sensorial

Ficha para teste de escala hedônica - Aceitabilidade geral de manjar branco

Nome:

Data:

\section{AMOSTRA:}

Avalie a amostra e circule o número na escala abaixo que indique a sua opinião geral sobre o produto.

9 = gostei muitíssimo

8 = gostei muito

7 = gostei moderadamente

6 = gostei ligeiramente

$5=$ nem gostei nem desgostei

4 = desgostei ligeiramente

3 = desgostei moderadamente

2 = desgostei muito

1 = desgostei muitíssimo

Cite o atributo que você mais gostou na amostra: :)

Cite o atributo que você menos gostou na amostra: :)

Comentários: 


\section{Anexo 3 - Modelo da ficha utilizada para recrutamento dos participantes da análise sensorial}

Recrutamento de provadores para análise sensorial de manjar branco

\section{Estamos convidando você para participar de uma análise sensorial de manjar branco.}

Esta análise será conduzida pela aluna de mestrado Sabrina Barros de Mattos Corrêa, sob orientação da Prof. Dra. Susana Marta Isay Saad do Departamento de Tecnologia Bioquímico-Farmacêutica FCF/USP.

O produto a ser avaliado apresenta os seguintes ingredientes:

Leite integral esterilizado tipo UHT, cultura lática, açúcar refinado, amido de milho, goma carragena, coco ralado e leite de coco.

O produto foi elaborado e acondicionado de acordo com as Boas Práticas de Fabricação de Alimentos, nos laboratórios do Departamento de Tecnologia Bioquímico-Farmacêutica FCF/USP.

Ao final das análises os provadores receberão um brinde mas não haverá remuneração financeira.

Portanto, se você quiser participar dessa análise, por favor, leia o Termo de Compromisso abaixo e preencha as informações a seguir:

Estou ciente do objetivo do teste, não apresento reação alérgica ou intolerância aos ingredientes, tenho entre 18 e 60 anos, costumo consumir produtos lácteos como leite fermentado, iogurte ou queijo, não estou fazendo algum tratamento médico (tomando algum medicamento) nem gripado e aceito participar dessa análise sem restrições. 


\begin{tabular}{|c|c|c|c|c|c|}
\hline Nome & Sexo & RG & Idade & E-mail & Assinatura \\
\hline & & & & & \\
\hline & & & & & \\
\hline & & & & & \\
\hline & & & & & \\
\hline & & & & & \\
\hline & & & & & \\
\hline & & & & & \\
\hline & & & & & \\
\hline & & & & & \\
\hline & & & & & \\
\hline & & & & & \\
\hline & & & & & \\
\hline & & & & & \\
\hline & & & & & \\
\hline & & & & & \\
\hline & & & & & \\
\hline & & & & & \\
\hline
\end{tabular}

